Universidade de São Paulo

Faculdade de Arquitetura e Urbanismo

\title{
Marisa Barda
}

A importância da arquitetura vernacular e dos traçados históricos para a cidade contemporânea

São Paulo

2007 
Universidade de São Paulo

Faculdade de Arquitetura e Urbanismo

\section{Marisa Barda}

A importância da arquitetura vernacular e dos traçados históricos para a cidade contemporânea

São Paulo

2007 
Marisa Barda

A importância da arquitetura vernacular e dos traçados históricos para a cidade contemporânea

Dissertação apresentada à Faculdade de Arquitetura e Urbanismo da Universidade de São Paulo, para obtenção do título de Mestre em Arquitetura e Urbanismo.

Área de Concentração: História e Fundamentos da Arquitetura e Urbanismo. Orientador: Prof. Doutor Paulo Julio V. Bruna. 
AUTORIZO A REPRODUÇÃO E DIVULGAÇÃO TOTAL OU PARCIAL DESTE TRABALHO, POR QUALQUER MEIO CONVENCIONAL OU ELETRÔNICO, PARA FINS DE ESTUDO E PESQUISA, DESDE QUE CITADA A FONTE.

ASSINATURA:

E-MAIL:

Barda, Marisa

B245i A importância da arquitetura vernacular e dos traçados históricos para a cidade contemporânea / Marisa Barda. -São Paulo, 2007.

154 p. : il.

Dissertação (Mestrado - Área de Concentração: História e Fundamentos da Arquitetura e Urbanismo) - FAUUSP.

Orientador: Paulo Júlio Valentino Bruna

1.Arquitetura vernacular 2.Arquitetura - Recuperação 3.Patrimônio histórico I.Título 
À lara, Marco e Alberto 


\section{Agradecimentos}

Agradeço às minhas amigas: Francesca Leonardis, pelas conversas estimulantes; e Haifa Sabbag pela paciência e carinho.

Ao meu orientador Prof. Paulo Bruna, grande estimulador e conselheiro, minha gratidão eterna.

Ao meu filho Marco que me ajudou com as imagens e montagem da tese. 
Barda, Marisa. A importância da arquitetura e dos traçados históricos para a cidade contemporânea. 2007. 154p. Dissertação (Mestrado) Faculdade de Arquitetura e Urbanismo, Universidade de São Paulo, São Paulo, 2007.

Não é possível fazer uma avaliação do patrimônio histórico somente por meio de valores estéticos; o desenho e os símbolos da cidade também se tornam memória na medida em que adquirem uma dimensão coletiva: é necessário considerar a importância da edificação como característica de um processo de reconhecimento do lugar e não da capacidade do seu autor. A cidade resulta das relações que cada elemento estabelece com todos os outros, da existência de traçados históricos e de edificações capazes de manter e traduzir a memória histórica do lugar, também e principalmente com aqueles espaços imateriais, como os vazios urbanos, ou com edifícios industriais, pois eles marcam o território.

Técnicas de expansão urbana foram substituídas - na Europa - por práticas de recuperação e remodelação fundamentadas na história, por meio de significados coletivos, intrínsecos e estratificados, ou seja, baseados nas tradições regionais e pertencentes à cultura popular. Esta se manifesta de modo muito diferente em cada região, em função de suas raízes, costumes e identidade.

Para exemplificar esse fenômeno, foram selecionadas duas situações de recuperação arquitetônica em Milão que se desenvolvem em duas escalas de interferência urbana diferentes, considerando em ambos os casos os efeitos de "re-equilíbrio" e impacto no entorno; um edifício de arquitetura vernacular com fortes relações com o entorno, cuja localização é central, e uma área extensa de obsolescência industrial de forte impacto urbano localizada em área periférica.

PALAVRAS-CHAVE: Traçados históricos, preexistências, arquitetura vernacular, espaço metavernacular, preservação, obsolescência industrial. 
Abstract:

Barda, Marisa. A importância da arquitetura e dos traçados históricos para a cidade contemporânea. 2007. 154p. Dissertação (Mestrado) Faculdade de Arquitetura e Urbanismo, Universidade de São Paulo, São Paulo, 2007.

It is not possible to make an assessment of the historical patrimony only by means of esthetical values; the design and the symbols of a city also become part of its memory as they acquire a collective dimension; it is necessary to consider the importance of the buildings as a characteristic of a process of knowing the place and not the skill of its author. The city is the result of the relationships that each element establishes with all the others, of the existence of a historical heritage and of buildings able to maintain and translate the historical memory of the place, also and mainly with those immaterial spaces, as the urban emptiness, or with industrial buildings, because they mark the territory.

Urban expansion techniques were substituted - in Europe - by recuperation and remodeling practices based on History, by means of collective, intrinsic and stratified meanings; that is, based on the regional and collective traditions belonging to popular culture. This culture manifests itself in very different ways in each region, as a function of its roots, habits and identity.

To exemplify this phenomena, two situations of architectural recuperation in Milan were selected that develop in two different scales of urban interference. In both cases the effects of "re-equilibrium" and impact on their surroundings were considered; a building of vernacular architecture with strong relationships with its surroundings in a central location, and a large area of industrial obsolescence with a strong urban impact situated in a peripheral area.

KEY-WORDS: Historical drawings - Pre-existences - Vernacular Architecture

Metavernacular Space - Preservation - Industrial obsolescence 


\section{Sumário}

Introdução

1. A Consciência Popular e os Valores Históricos, Urbanos e de Conservação da Cidade

2. A Importância dos Traçados Históricos

3. Arquitetura Vernacular e Espaço Metavernacular

4. Extensão do Conceito de Preservação.

5. Estudo de Casos

Conclusão

Bibliografia

Ilustrações 


\section{Introdução}

Estender o conceito de preservação de monumentos até o aspecto da cidade como um todo tem a finalidade de obter uma nova postura nas intervenções urbanas, cujo tecido histórico - como trama do existente - deve ser considerado dentro do seu contexto tal qual um sistema contínuo de referências para a transformação e tutela dos valores históricos e culturais.

Com essa abordagem, a importância da conservação não se limita somente a monumentos arquitetônicos, mas abrange também a arquitetura vernacular, uma arquitetura "menor", não necessariamente antiga, que reflete um determinado momento histórico da cidade, relacionando-o à formação de suas ruas e bairros. A conservação diz respeito, neste caso, a espaços metavernaculares (neologismo por mim empregado), ou seja, a edifícios públicos, edifícios industriais, espaços intermediários, jardins que dividem um espaço privado da rua ou até mesmo a vazios urbanos que ao longo do tempo conseguiram estabelecer inter-relações entre o espaço urbano e os indivíduos, entre os espaços públicos, privados e semiprivados.

É preciso lembrar que o termo conservação vem acumulando inúmeros conceitos, equívocos e variações do mesmo teor como reestruturação, revitalização ou recuperação. Essas nuances e diferentes interpretações deveriam ser cuidadosamente estudadas e analisadas para uma melhor compreensão. Mas não é intenção discutir aqui sobre métodos ou técnicas dessa disciplina, embora estejam apontados em alguns momentos do trabalho.

Os conceitos aqui adotados são, em sua grande maioria, criados por historiógrafos, antropólogos, arquitetos ou mesmo urbanistas, em sua maioria, 
italianos, elaborados a cerca de cinqüenta anos na Itália e, mais recentemente, na Europa. Na Itália, como é sabido, o sentimento de sacralidade do espaço e das preexistências históricas foi e é sempre muito forte.

No Brasil, ao contrário, não existe interesse por parte do cidadão, e mesmo do arquiteto, pela arquitetura vernacular ou pelos espaços "metavernaculares", tão apreciados no exterior. Aqui, destroem as construções sem se dar conta do significado que representam como referências para criar ou modificar as relações entre os diversos aspectos do território urbano, da importância histórica que têm e que vai além de aspectos arquitetônicos físicos e estéticos.

A idéia deste trabalho não é propor soluções para São Paulo ou para qualquer outra cidade; porém, indiretamente, São Paulo será sempre pano de fundo de algumas situações e suas possibilidades. E a Itália, mais especificamente Milão, uma referência, apesar de este país não ter dado muitas oportunidades aos arquitetos de criarem, oferecendo, por outro lado e devido à sua própria condição histórica, contribuições teóricas extermamente interessantes.

A indicação de "não mais se expandir, mas recuperar áreas obsoletas" está sendo adotada em grande escala no mundo todo. A intenção, portanto, é analisar questões referentes a valores históricos, urbanos e de conservação, com ênfase nos bens culturais e nas relações existentes entre o patrimônio construído e a cidade, ou em outras palavras, entre espaços e arquitetura "metavernaculares". Porque são espaços que deixaram signos e símbolos espaciais também na mente dos cidadãos. 
Dividido em quatro capítulos, o ponto focal de cada um foi a indagação: "até que ponto o novo pode apagar a história?"

O primeiro capítulo aborda as teorias sobre a preservação das preexistências históricas e ambientais e sua importância, que envolvem na mesma medida tanto a arquitetura quanto o urbanismo e a sua pertinência no desenvolvimento das identidades individual e social, apontadas desde a década de 1940 por Ernesto N. Rogers, arquiteto italiano e diretor da revista de arquitetura Casabella Continuità.

Não é possível fazer um juízo sobre o patrimônio histórico somente por meio de valores estéticos. A forma e os símbolos da cidade também se tornam memória na medida em que adquirem uma dimensão coletiva; é necessário considerar o significado da edificação como característica de um processo de reconhecimento do lugar e não da capacidade de seu autor. Daí a importância do conceito de tipologia, nesse caso delineado através do ponto de vista de historiógrafos e arquitetos que o estudaram mais a fundo.

O segundo capítulo tenta diferenciar o espaço público e o privado da cidade contemporânea. As teorias estão relacionadas com os conceitos de espaço na cidade contemporânea e de não-lugar do antropólogo francês Marc Augé (1993) em contraposição ao genius loci romano, desenvolvido por vários autores, principalmente pelo arquiteto norueguês Christian Norberg-Schulz (2003).

Correndo algum risco, o terceiro capítulo tenta definir e diferenciar a arquitetura vernacular dos monumentos, o espaço público do espaço privado e a presença ou não de identidade e cidadania. Como afirma Léon Krier em "Carta Per La Ricostruzione Della Città Europea": 
somente em uma relação dialética entre Arquitetura e Edificação, entre cultura clássica e popular, entre público e privado, pode-se dar aos abrigos humanos a dignidade e a cultura coletiva. Sob o ponto de vista filosófico, Clássico e Vernacular não estão baseados na diferença de classes, mas na diferença entre coletivo e individual, entre monumentos e edificações públicas e urbanas, entre habitações privada e popular ${ }^{1}$.

As indicações oferecidas pela história não são vínculos indissolúveis, mas elementos reconhecíveis e material analítico de reflexão. Nessa perspectiva, a arquitetura vernacular é uma ponte entre a história e a arquitetura.

No quarto capítulo, são abordados a questão da extensão do conceito de conservação e o significado que isso comporta para uma cidade contemporânea ou mesmo para uma metrópole.

Invejamos as cidades européias sem perceber que mesmo no pequeno lapso de tempo que ocorreu desde a formação do Brasil e a história de suas cidades, demolimos ao invés de tentar entender e manter o que é importante para uma identidade. Lembramos que esse fenômeno acontece da mesma maneira no indivíduo; sua formação depende de suas origens, antecedentes, educação e regras; quando esses fatores não estão presentes, foram destruídos ou não fazem parte de suas reminiscências (anamnese), o indivíduo perde parte de si mesmo.

A questão espacial é também abordada na psicologia e considerada essencial na formação de um indivíduo. Convém observar nesse sentido que a deusa Héstia, divindade feminina primordial na Grécia, ou Vesta no mundo romano, foi considerada o coração da vida grega, o fogo sagrado, também

\footnotetext{
${ }^{1}$ As traduções de textos do italiano para o português são de minha autoria.
} 
venerado em outras religiões antigas. Sua imagem era considerada arquitetônica, justificada pelo seu papel de guardiã dos lares e por ter sido a divindade que primeiro construiu uma casa. A psicologia atualmente considera Héstia a revisão da alma em termos de metáforas espaciais, recordando o poder que ela tem de conduzir a alma a um estado de moradia; a perda da Héstia, da moradia, é uma ameaça para a psique como um todo; não há limites que distingam a intimidade da moradia interior e o mundo externo, pois não há uma casa psíquica que ofereça paredes protetoras (HILLMAN, 1980).

Para concluir, no quinto capítulo são realizados dois estudos de casos; para isso, foram selecionadas duas situações de recuperação arquitetônica em Milão que se desenvolvem em duas escalas de interferência urbana diferentes; o primeiro, na escala do projeto arquitetônico por meio da análise da recuperação de uma construção de arquitetura vernacular de uso misto. O segundo, na escala metropolitana por meio de estudo do projeto de um pólo integrado em uma área de obsolescência industrial, da Pirelli-Bicocca, onde até o início dos anos 1980 funcionava a fábrica da Pirelli. Para uma melhor compreensão dos dois casos, é apresentado um breve desenvolvimento da história e do urbanismo milanês. Nos últimos decênios, Milão, assim como Roma, não participaram concretamente - como fizeram outras grandes cidades européias, Paris, Barcelona e Berlim - do debate arquitetônico relativo às grandes transformações urbanas. Atualmente, estas cidades italianas estão tentando reafirmar seu papel nas esferas arquitetônica e urbanística internacionais por meio da experiência das outras metrópoles. 
O texto se desenvolve em uma dialética contínua entre tempos históricos diferentes porque são fatos que se repetem e suas interferências estão presentes, seja direta, seja indiretamente. 


\title{
1. A Consciência Popular e os Valores Históricos, Urbanos e de Conservação da Cidade
}

\begin{abstract}
Enquanto nas cidades gregas os edifícios eram corpos articulados, compostos por componentes individuais, os monumentos romanos não foram concebidos para serem organismos independentes, mas sim conjuntos integrantes e espaços fechados no interior de um complexo urbano maior. (NORBERG-SCHULZ, 2003, p. 138)
\end{abstract}

$\mathrm{Na}$ Europa, particularmente na Itália, as inter-relações entre as pessoas, a cidade, a arquitetura, o design, a moda e até mesmo o próprio quotidiano são permeadas pela história. A formação urbana resulta de um grande número de sobreposições ao longo dos séculos. As cidades não são apenas uma somatória de edificações, elas têm um passado e uma forte ligação com o território onde os traçados históricos são sempre respeitados. É em razão dessa convivência, diretamente vinculada aos valores ancestrais, que o povo italiano tenta se afirmar.

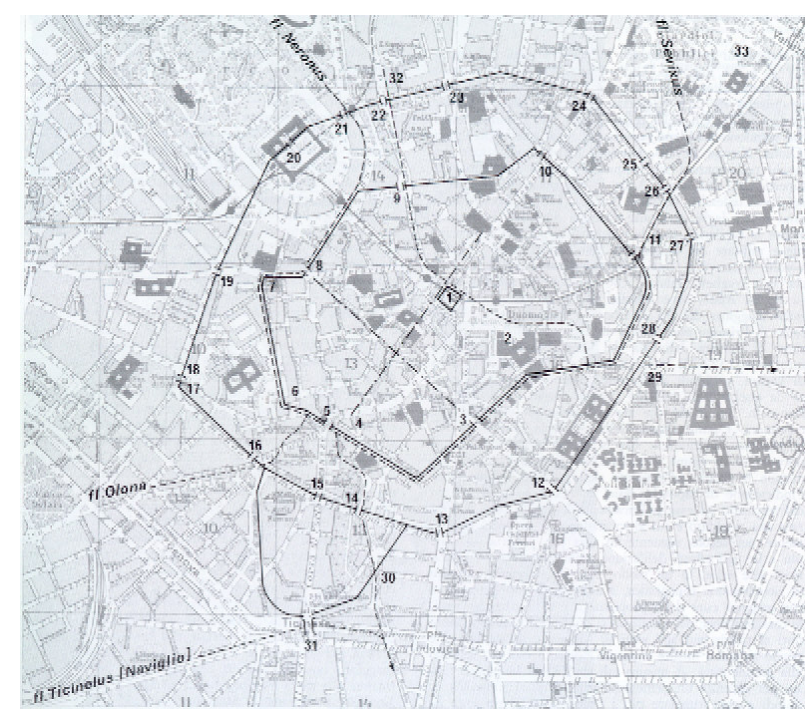

Fig. 1 - Sobreposição mapa Milão 1980/ Muralhas romanas século I 
Quando Secchi afirma que "a história da cidade européia é a história da lenta modificação das relações entre o corpo e o espaço aberto ou coberto, coletivo ou privado", podemos supor a mudança das idéias e das relações sociais, como também a inércia das formas espaciais:

A suposta cidade barroca, como a neoclássica e mais tarde a moderna, nunca conseguirão conquistar todo o espaço urbano. Mas cada uma das formas de cidade do passado, mais que depositar arquiteturas no território, deixou a idéia e o testemunho de uma experiência espacial diversa, em particular, de uma experiência diversa do espaço aberto, individual e coletivo e de sua relação com aquele coberto (SECCHI, 2000, p. 152).

Nesse sentido, tanto os centros antigos, como a cidade moderna, constituem obviamente um patrimônio para toda a coletividade: nos centros antigos e na cidade moderna gradualmente se concretizou a história de

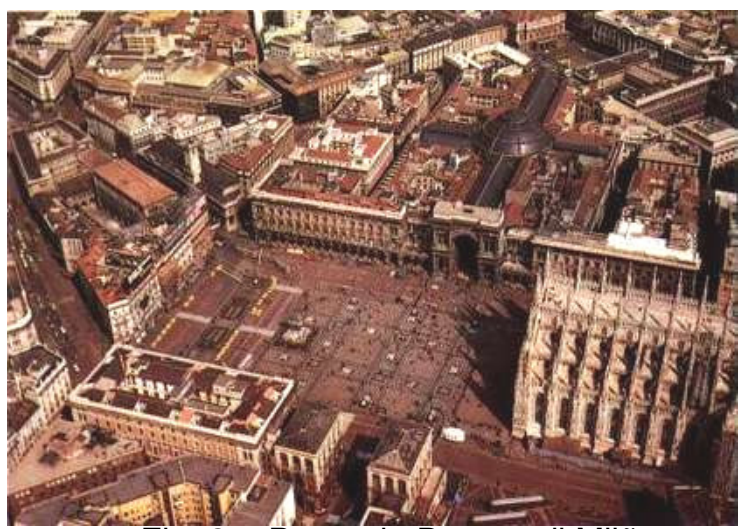

Fig. 2 - Praça do Duomo di Milão

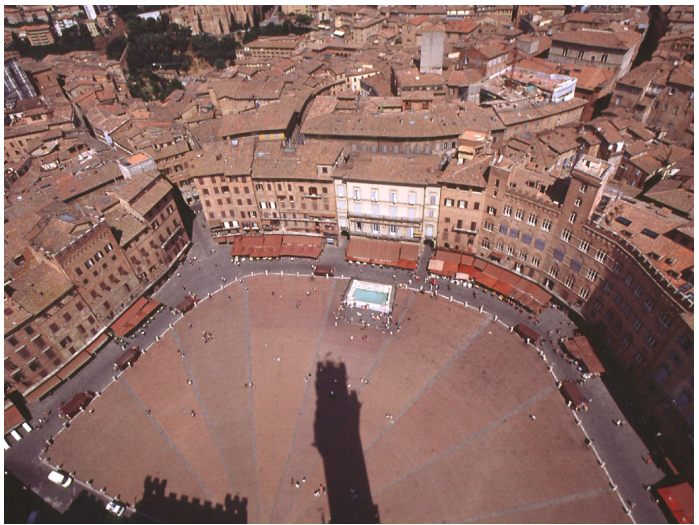

Fig. 3 - Praça de Siena

sociedades inteiras e de culturas do passado; muitas de suas características táteis, visíveis, sonoras e olfativas estão ainda presentes, ou vivas na memória de alguns de seus habitantes; não surpreende que alguns queiram, com diferentes intenções, conservá-las. 
Por outro lado, o crescimento da cidade antiga, tendo como referências contextos sociais bem estáticos e de lenta transformação, favoreceu uma construção organizada por necessidades comuns, uma espécie de senso estético coletivo expresso por uma comunidade que poderia ser considerada homogênea, segundo modelos adquiridos coletivamente.

Desde a antiguidade mais remota, afirma Argan, a cidade configurou-se como um sistema de informação e de comunicação, com uma função cultural e educativa. Já na época de Homero, a cultura era considerada, acima de tudo, o conhecimento das cidades:

Os monumentos urbanos tinham uma razão não apenas comemorativa, mas também didática: comunicavam a história das cidades, mas comunicavam-na em uma perspectiva ideológica, ou seja, tendo em vista um desenvolvimento coerente com as premissas dadas (ARGAN, 1993, p. 244).

A realização de uma construção, mesmo quando determinada por exigências de ordem prática, é também um dos meios utilizados desde sempre pelo homem para representar, mais ou menos conscientemente, a própria noção de vida social, da qual a arquitetura e o desenho urbano são sempre sua concretização.

Sob este ponto de vista, também podemos considerar primária a habitação como objeto de conhecimento e de construção da cidade. Cada casa tem raízes profundas na cultura de um povo e também nas estratificações da história, mas é a partir da Idade Média que a hierarquia social e econômica muda com a transferência do campo para a cidade da burguesia nascente e das riquezas emergentes de alguns senhores rurais. 


\section{Tipologia Arquitetônica}

Entender o significado da relação entre tipo arquitetônico e forma urbana é fundamental para compreender a estruturação urbana e para subsidiar a metodologia do projeto arquitetônico e urbanístico.

$\mathrm{Na}$ cultura da arquitetura da cidade tradicional na Europa, a estreita ligação entre habitação e cidade é tal que, em muitos casos, torna indivisível a relação entre tipo de edificação e a própria forma da cidade. A identificação entre arquitetura e cidade, sem dúvida, resulta mais forte na cidade histórica e, cada vez menos, na cidade contemporânea.

A tipologia não significa uma simplificação da complexidade, nem a construção de modelos simples e repetíveis que possam oferecer fundamentos a certas disciplinas arquitetônicas. É, ao contrário, a pesquisa de um sentido, ou de muitos possíveis sentidos, que vão além da forma na qual o objeto é delimitado, a pesquisa do sentido oculto das coisas pela estratificação de imagens e significados dos quais o objeto é depositário. Um sentido que se pode colher somente percorrendo todos os significados, os tempos e alcançando, assim, a desvinculação "do tipo como forma"

Embora os estudos de tipo e tipologia remontem aos séculos XVIII e XIX quando pesquisadores da arquitetura buscavam os tipos e modelos dos "projetos ideais", os estudos foram particularmente desenvolvidos pelo tratadista francês Quatremére de Quincy, e retomados, tentando criar um nexo entre tipologia construtiva e morfologia urbana como uma reação à Arquitetura e ao Urbanismo Modernos, principalmente por arquitetos ou historiógrafos italianos, entre eles, Carlo Aymonino, Giulio Carlo Argan (1909-1992), Vittorio Gregotti e Aldo Rossi (1931-1995). 
Eles se interessaram de modo bem específico em estudar e aprofundar os conceitos de tipo. Inúmeros outros autores se dedicaram ao estudo da tipologia arquitetônica, mas é a partir do ponto de vista de cada um desses quatro estudiosos que se tentará aqui entender seu amplo significado. Aymonino tem um enfoque mais urbano; Argan, como é esperado, aborda a questão sob um aspecto ligado à história da arquitetura; Rossi tem uma visão ligada à morfologia da arquitetura, enquanto Gregotti analisa a semântica da tipologia do território urbano.

Todos os quatro são unânimes ao afirmar que o tipo é, portanto, uma concepção totalmente antimoderna da forma, compreendida não como ato de afirmação e definitivo, mas como reabertura da dimensão de possibilidades e de novo significado de um objeto.

"Os instrumentos da morfologia urbana e da tipologia arquitetônica", afirma Carlo Aymonino,

\begin{abstract}
servem para análises - comparativas ou não - do "existente" (compreendem também as soluções não realizadas ou realizadas parcialmente, como parte integrante de uma história urbana) mudando substancialmente seu valor até o desaparecimento total de seu caráter ordenador se a hipótese "a ser realizado" é aplicada (AYMONINO, 2000, p. 145).
\end{abstract}

O importante é que a relação entre tipologia construtiva e morfologia urbana se mantenha como parâmetro de referência que une o passado e 0 presente.

Para Aldo Rossi, o tipo vai se constituindo segundo necessidades e segundo aspirações de beleza; único, se bem que bastante variado em diferentes sociedades, está ligado à forma e ao modo de vida. Portanto, é 
lógico que o conceito de tipo se torne um fundamento para a arquitetura e seja aplicado tanto na prática como nos tratados.

Ele usou o conceito de tipo e "modelo" de Quincy: "A palavra tipo não representa tanto a imagem de uma coisa a ser copiada ou imitada perfeitamente, como a idéia de um elemento que deva servir de regra ao modelo. (...) O "modelo", entendido segundo a execução prática da arte é um objeto que deve se repetir tal como é; o tipo é, pelo contrário, um objeto segundo o qual, qualquer pessoa pode conceber obras que não se assemelharão entre si. "Tudo é preciso e fornecido pelo modelo, tudo é mais ou menos vago no tipo (ROSSI, 1978, p. 31) e partir desse conceito, ele enfrentou a discussão sobre a arquitetura da cidade e a importância de sua continuidade histórica, estudando os elementos dos quais as cidades são compostas e a forma como eles se agrupam para formar os bairros, identificando o tipo como o elemento fundamental da arquitetura.

O nascimento de um tipo está condicionado ao fato de já existir uma série de edifícios que têm entre si uma evidente analogia formal e funcional: em outros termos, segundo Argan quando um tipo se fixa na prática ou na teoria arquitetônica ele já existe - numa determinada condição histórica da cultura como resposta a um conjunto de exigências ideológicas, religiosas ou práticas. Acrescida com o pensamento de Aymonino, a tipologia arquitetônica se torna um instrumento indispensável não tanto pela classificação do existente como pelas indicações operativas de projeto, ou seja, não é mais um método de análise das necessidades, mas sim a catalogação de protótipos que já definiram e resolveram aquelas mesmas necessidades. 
"Nenhum tipo se identifica com uma forma mesmo se todas as formas arquitetônicas sejam relacionadas a tipos", afirma Aldo Rossi (1978, p. 32). A tipologia, segundo ele, se apresenta como o estudo de tipos dos elementos urbanos - não mais reduzíveis - tanto de uma cidade como de uma arquitetura. Assim sendo, nota Argan, as séries tipológicas não se formam na história da arquitetura apenas em relação às funções práticas dos edifícios, mas especialmente em relação à configuração deles. Isto é, o tipo é sempre deduzido da experiência histórica; trata-se, porém, de observar por que, no processo ideativo do artista que traça o projeto de uma obra arquitetônica, a experiência da história se configura, ao menos em parte, como esquema tipológico.

O tipo é uma constante e se apresenta com caráter de necessidade; mesmo quando determinado, reage dialeticamente com a técnica, com as funções, com o estilo, com o caráter coletivo e 0 momento individual do fato arquitetônico (ROSSI, 1978, p. 33).
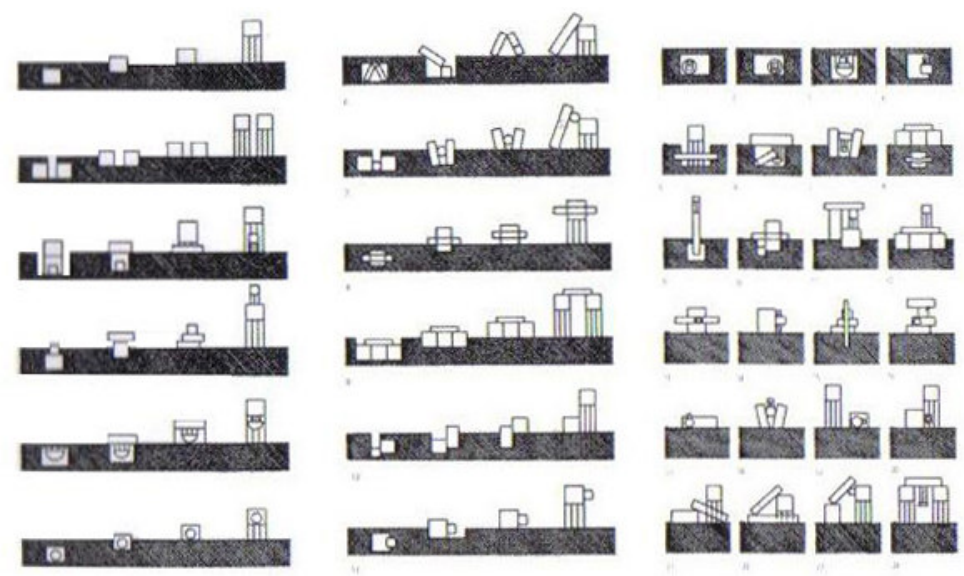

Fig. 4 - Diferentes disposições de objetos em um terreno. 
Para Gregotti, a tipologia - disciplina que se ocupa da discussão, classificação e fundamentação dos tipos - constitui-se, pelo conjunto de seus resultados e métodos, em uma matéria importante para a arquitetura.

Porém, muitas disciplinas, além da arquitetura, da matemática à sociologia, da geografia à literatura, fazem largo uso do conceito de tipo. Assim sendo, um mesmo fenômeno, sob o ponto de vista de Gregotti, pode ser submetido a esquemas tipológicos diversos, segundo a ótica com que se analisam suas relações constitutivas internas e referenciais e segundo a utilização que se queira fazer daquele fenômeno.

Portanto, pode-se falar de tipos de ambientes geográficos, de tipos de ocupação agrária do solo, de tipos de utilização funcional, de tipos de circunscrições formais, de "tipos de circunstantes, de tipos de tecido urbano, de tipos de cidade, de tipos" de construção, de tipos de bens de consumo, etc., mas "é possível corresponder a cada um destes mesmos tipos diversas ordenações tipológicas ou remontar a diversos tipos ideais", conforme observa Gregotti (1977, p. 149).

Aymonino reitera que não existe uma única definição de tipologia arquitetônica; esta é redefinida a cada vez, em função das pesquisas que se queiram realizar. De acordo com ele, o conceito de tipologia encontrou, ao longo do século XIX, um campo de aplicação principalmente nos equipamentos urbanos destinados à coletividade que, exatamente por se apoiarem em exemplos tipológicos, se tornavam pontos de referência da cidade "ampliada" até se constituir, nos melhores exemplos, um verdadeiro sistema urbano. Nesse processo, as quantidades residenciais - apesar de terem sido individuadas pelos tratadistas como "edifícios privados na cidade e na área 
rural" - foram delegadas a um papel subalterno em relação ao conceito de tipologia ou então foram totalmente ignoradas (AYMONINO, 2000).

No exame sobre a formação do conceito de tipologia arquitetônica, Aymonino constatou como o próprio conceito - na sua acepção moderna tende a definir-se independente das relações com a morfologia urbana e, como resultado, as concretas tipologias arquitetônicas tenham adquirido um caráter de legitimização, aplicável em todos os casos de desenvolvimento das cidades em metrópoles, com base em uma economia do tipo capitalista. E como essa legitimização tenha, por sua vez, influenciado a morfologia urbana que, em muitos casos, de determinante tornou-se determinada pelas tipologias arquitetônicas delas "independentes"; assim (como conseqüência), a relação entre os dois termos foi substancialmente mudada.

Gregotti (1977) ressalta a importância semântica do tipo, não só do ponto de vista de seu uso, mas do significado que este assume como elemento de referência de vida associada, na qual se solidificam uma série de juízos de valor acerca da condição histórica, da relação com a tradição e da esperança no futuro. Às vezes, ele também aponta o significado do tipo em relação à própria concepção cosmológica de um grupo humano e de um certo modelo de cultura.

Entretanto, para Argan (2001), todo projeto arquitetônico tem um aspecto tipológico, seja no sentido de que o arquiteto busca conscientemente aproximar-se de um tipo ou afastar-se dele, seja no sentido de que toda obra arquitetônica visa, definitivamente, colocar-se como um tipo.

Na visão de Aymonino (2000), a tipologia arquitetônica é determinada pelo planejamento urbano - relações entre quarteirões, percursos, eventuais 
pontos (praças, rios, canais, etc.) - o que, por sua vez, é fruto de uma somatória de tipos arquitetônicos similares ou iguais, determinados por novas exigências mercantis ou residenciais que não possuem mais nenhuma forma de referência nem de dimensionamento ou funcionalidade com os tipos arquitetônicos precedentes, tanto de origem medieval, fundiária ou arquitetônica. Desta maneira, a dimensão arquitetônica coincide com partes de cidades e uma não tem significado se tomada isoladamente, mas o assume se está relacionada tanto dentro do quarteirão como dentro de vários quarteirões que compõem a parte.

Por outro lado, para Argan, o momento da aceitação do tipo é um momento de suspensão do juízo histórico; como tal, é um momento negativo, mas "intencionado" no sentido da formulação de um novo valor na medida em que, pela sua própria negatividade, coloca para o artista a necessidade de uma nova determinação formal, de uma ideação. Fica claro que a posição do artista em relação à história tem dois momentos: da tipologia; e da definição formal.

Com a transformação das condições históricas, sempre que a invariante tipológica supera uma certa distância da escolha fenomênica estabelece-se segundo Gregotti, uma diferença, uma tensão com a realidade que se resolve com a construção de um novo tipo a partir de um novo exame da realidade, da qual participa a esquematização tipológica em questão.

Argan reforça esta idéia ao lembrar que arquitetura industrial, respondendo a exigências totalmente novas, criou novos tipos que freqüentemente tiveram uma grande importância para os desenvolvimentos posteriores das formas arquitetônicas. 


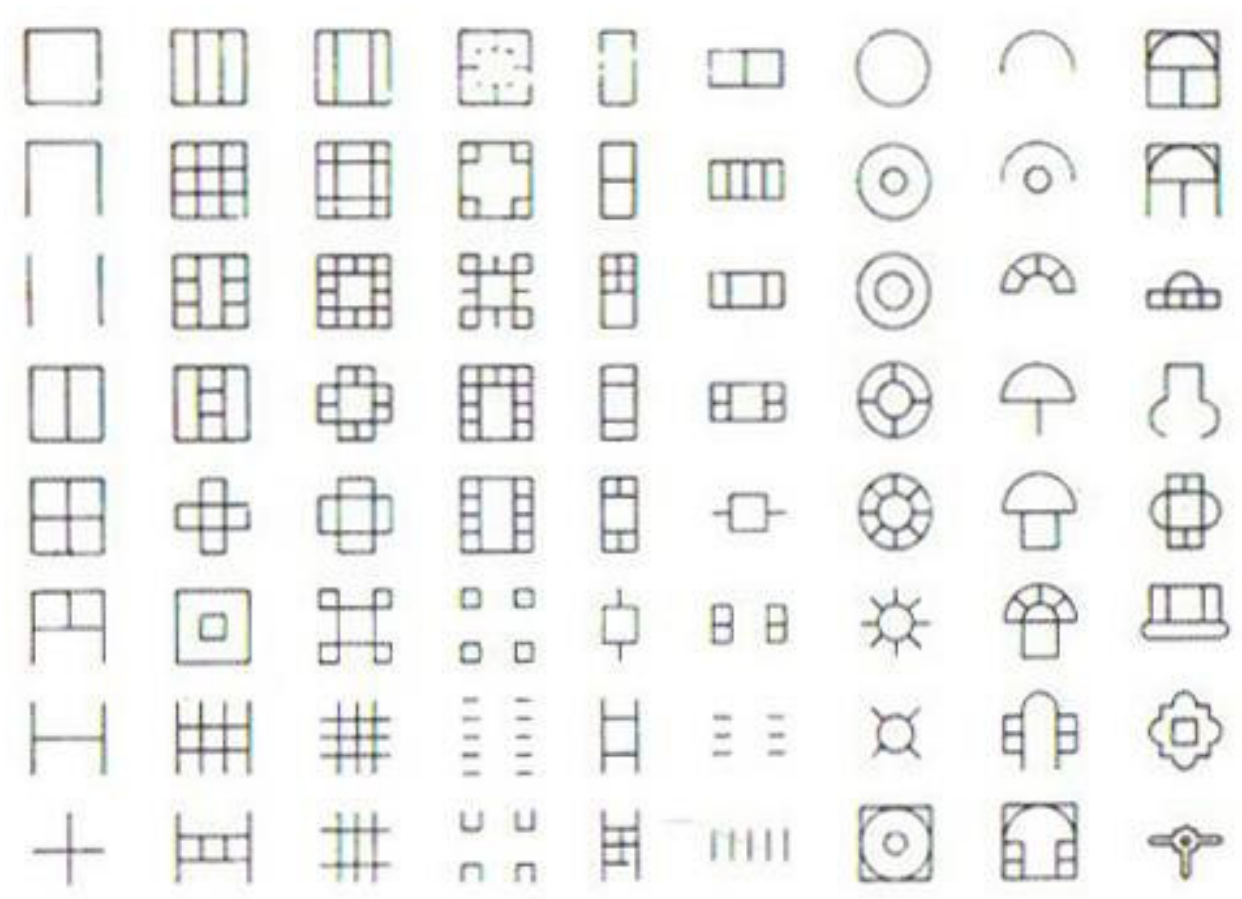

Fig. 5 - Divisões do quadrado, do paralelogramo e suas combinações com o círculo.

Gregotti (1977) afirma que os conceitos que temos atualmente de função e "fruição", vão se diluindo numa continuidade de mutações de uso e significado e, por isso, a idéia de transformação e variação acaba coincidindo com a própria idéia de uso; o sentido da arquitetura está vinculado intrinsecamente e cada vez mais à capacidade de compreender e solidificar o significado da mutação. Esta capacidade não está simplesmente ligada à definição tipológica, senão, mais genericamente, à forma do objeto arquitetônico; não se pode obtê-la apenas mecanicamente pela transformação física desse objeto ou de sua indiferença funcional, mas também por meio de um novo estudo de formas e de suas modificações que institui pelas qualidades do significado (qualidade densa em estratos e capaz de pôr em movimento continuas e diversas decodificações), uma dialética com a multiplicidade de usos e uma rede de situações possíveis. 
Aymonino não duvida sobre o mérito do movimento funcional estender a temática da tipologia arquitetônica à quantidade de residências, que até então - salvo poucas exceções - era prerrogativa da intervenção privada e de seus instrumentos aperfeiçoados (loteamentos, regulamentos, vínculos, etc.) todos referidos a uma "quantidade urbana" genérica (planos de expansão ou desenvolvimento) sem nenhuma relação com edifícios definidos arquitetonicamente.

Continuando, a possibilidade de criar uma relação entre tipologia arquitetônica e a morfologia urbana muda substancialmente na época contemporânea, quando as mudanças não parecem acontecer como fenômenos comparáveis tout court com aqueles do passado, mas parecem se abrir a novas hipóteses que partem da constatação da perda de significado do termo "forma urbana" (AYMONINO, 2000).

Finalizando, Rossi sustenta que tipo significa a própria idéia da arquitetura, ou tudo o que está mais próximo à sua essência. Ou seja, aquilo que apesar de qualquer mudança sempre se impôs "ao sentimento e à razão", tal como o princípio da arquitetura e da cidade. 


\section{O Valor de Historicidade da Cidade e seu Patrimônio Arquitetônico}

Por um longo período, digamos por toda a época medieval, a cidade era totalmente separada do campo, muito compacta, defendida por espessos muros. Isto definia não somente o caráter da cidade, como suas relações com o território. O espaço da cidade, urbano e público, era delimitado, embora na praça medieval tudo acontecesse. No século XVI, no entanto, a cidade modificou-se e ampliou-se satisfazendo, em boa parte, uma espécie de anseio estético comum aos cidadãos. Imediatamente após o Renascimento iniciou-se uma história diferente, denominada por Leonardo Benévolo (1991) como "A conquista do infinito", a partir da dimensão do infinito de Galileo Galilei e depois de Leibniz. A idéia do infinito, que tanto fascina a cultura ocidental, é encontrada na cidade renascentista onde os espaços se diversificam, se especializam - da rua, à praça, ao teatro - e em cada um ocorrem diferentes ações,

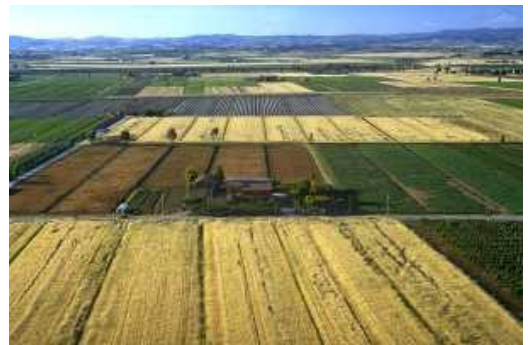

Fig. 6 - Campo rural

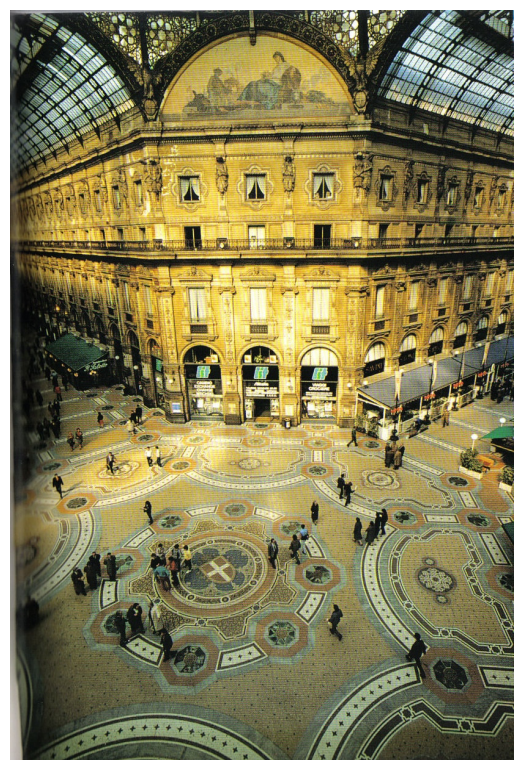
de maneira muito clara. O espaço da cidad€ Fig.7-Galeria Vittorio Emanuele. contemporânea, ao contrário, não possui essa clareza; ele é constituído pelos fragmentos, resultantes dos espaços que sobram após as construções de edifícios.

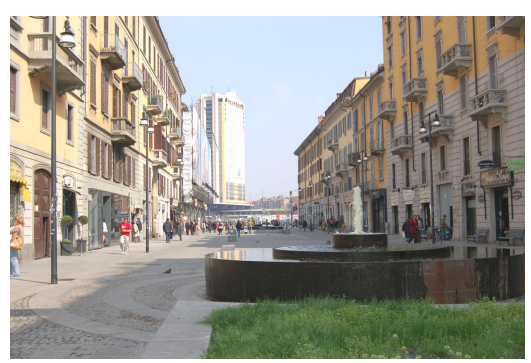

Fig. 8 - Uma rua de Milão 
As primeiras reflexões que Bernardo Secchi faz em relação à cidade antiga estão relacionadas com a adequação do espaço para o público: uma questão que não está relacionada somente com as formas, as dimensões e articulações desses espaços, mas também com as condições do micro-clima construído pelas dimensões dos espaços não construídos, da orientação dos edifícios, dos materiais utilizados para uns e para outros. Em seguida, estritamente interligada às primeiras, está a natureza do espaço aberto: ruas, praças, pátios internos, jardins, trechos de campo delimitados. Por fim, o espaço aberto que a cidade medieval estabelece com o edifício, através de dispositivos específicos, relações variadas e extremamente complexas que se revelam em espaços desconexos, continuamente variáveis (SECCHI, 2005).

Gregotti também reforça esses conceitos quando observa que "a cidade é dotada de particular capacidade de conservação da estratificação histórica dos signos, aos quais a comunidade atribui um valor particularmente elevado; a cidade, portanto, não pode ser considerada somente como um fenômeno de edificação; ela reúne mais valores e significados do que o ambiente territorial" (GREGOTTI,1966, p. 65).

\begin{abstract}
Assim sendo, a questão, sobre a importância das preexistências históricas, enfrentada de forma muito sensível por Rogers, parte de sua premissa de que(...) a história nunca foi definida como sendo um sistema estático e foi sempre resolvida com uma sucessão de mutações que transformaram um presente em um outro. Portanto seria lógico concluir que, não só não se pode impedir que a sociedade contemporânea se expresse, mas é de basilar importância afirmar nossa presença temporal, com a nossa natural ocupação no espaço (E. N. ROGERS, 1958, p. 276).
\end{abstract}

Ludovico Quaroni (1981) em La città física tem um enfoque muito parecido: para ele, na cidade, aproximam-se, misturam-se, e se sobrepõem 
elementos naturais e humanos: o ar, a luz, o solo, a água, a vegetação, as construções feitas pelo homem. Esses elementos, quando condições fortuitas de cultura e civilização regularam o uso - para nossa felicidade, freqüentemente, e de modos quase naturais - geram uma composição, no sentido arquitetônico da palavra, ou seja, um organismo perfeitamente completo e unitário. A unidade é característica indispensável e fundamental da composição, tanto para o edifício em si quanto para a cidade: para que um conjunto possa se chamar organismo, não se deve poder tirar ou acrescentar nada sem alterar irremediavelmente o equilíbrio preexistente, sem comprometer a unidade. Isto não significa que a cidade deva ser considerada como algo estático, imutável no tempo e no espaço; como todos os organismos, a cidade também está sujeita a transformações, mas estas devem ser sempre reguladas pelas leis da composição (QUARONI, 1981).
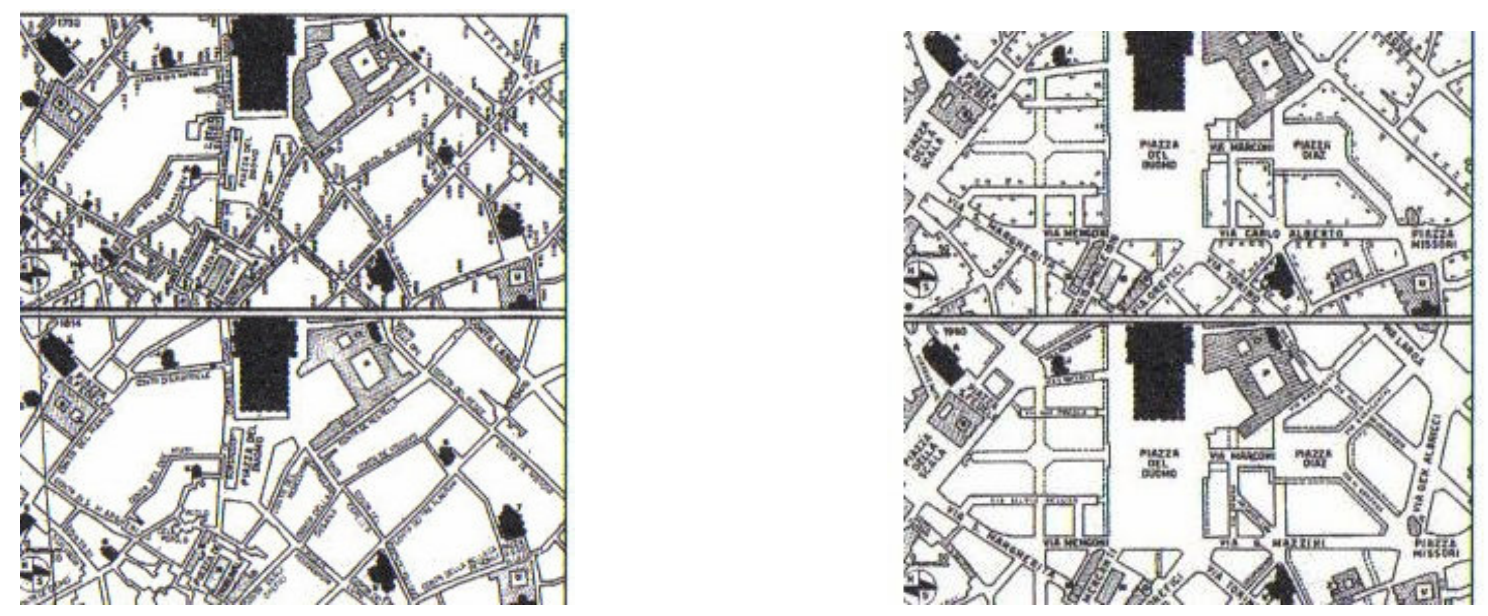

Figura 9 - Variações da estrutura urbana na praça do Duomo em Milão de 1730 a 1960

E. N. Rogers afirmava também que, ao favorecer o processo criativo de nossas obras, elas, além de não condicionarem negativamente o existente, podem potencializá-lo, ao construir uma ponte entre o passado e o 
futuro: "o futuro depende em parte de nós, como nós dependemos em parte do passado: tradição é esse perpétuo fluir e ser moderno é participar conscientemente como elemento ativo desse processo" (ROGERS, 1958, p. 276).

Nesta dialética entre obras do passado e obras do futuro é importante deixar claro que, além da organização, deve existir fundamento histórico no conjunto da cidade, isto é, tanto na cidade antiga como na moderna. "Pôr em discussão sua historicidade global equivale a pôr em discussão o valor ou a legitimidade histórica da sociedade contemporânea, que talvez alguns queiram, mas que o historiador não pode aceitar" (ARGAN, 1993, p. 79).

A cidade histórica pode ser o motor de transformação para uma modernização qualitativa da cidade contemporânea, portanto

\begin{abstract}
o historiador deve preocupar-se não com o congelamento ou a fixação da cidade antiga, da qual pode apenas prorrogar a existência, mas com um desenvolvimento coerente com a sua realidade histórica, de modo que, mesmo na diversidade das organizações e dos níveis, uma articulação funcional assegure o dinamismo de todo tecido urbano (ARGAN, 1993, p. 81).
\end{abstract}

No início do século $\mathrm{XX}$, o estudo da cidade começa a ter forte aproximação com temáticas sociológicas, relacionáveis tanto com a ideologia marxista quanto com a obra de Max Weber e de Louis Mumford, iniciando-se a afirmação de uma metodologia interdisciplinar. Vale afirmar que o caráter orgânico do sistema urbano é dado pela história, mesmo quando a cidade é recente. Mas, ao considerar a concentração urbana, temos que refletir também sobre todas as conceituações realizadas no início do século XX, a partir da oposição da cidade-campo de Marx-Engels; a cidade como fruto da divisão do 
trabalho (Smith), a cidade como lugar de uma extraordinária concentração de poder (Weber); a cidade como produto da revolução industrial (Landes).

Não há nada de novo nisso; foram utilizadas aqui as contribuições mais diversas para proceder à formação de uma teoria de fatos urbanos que tenha correspondido com a realidade. No livro // território della architettura (O Território da Arquitetura), Gregotti evidencia como a dilatação do fenômeno urbano sobre territórios de inusitada dimensão, induzem a criação de novas relações com os caracteres topográficos de cada parte do território que tenha um projeto urbano ou de arquitetura. Em seu livro L'architettura della città (A Arquitetura da Cidade). Aldo Rossi interpreta a história da cidade européia como sendo uma contínua construção e redefinição dos caracteres tipológicos do espaço urbano. Venturi, em Complexidade e Contradição na Arquitetura abre caminho para a aceitação de uma experiência urbana, em que, como nas cidades italianas do antigo regime por ele estudadas profundamente, a adaptação e a estratificação prevalecem sobre a afirmação rígida de um princípio. Outros textos falam sobre a cidade e sobre sua história com pontos de vista diferentes daqueles do passado, entre os quais os de Giedion, Banham, Tafuri, Jane Jacobs, Koolhaas.

Em tempos remotos, mas não só neles, a sobrevivência dependia de uma boa relação com o lugar, tanto no sentido físico quanto psíquico. Portanto, as cidades devem ser tratadas como lugares individuais e não como espaços abstratos onde as forças cegas da economia e da política podem se expandir livremente; respeitar o genius loci não significa re-copiar os modelos antigos, mas colocar luz sobre a identidade do lugar e interpretá-la de maneira nova. 
Desde a antiguidade o genius loci, o espírito do lugar, foi considerado como sendo aquela realidade concreta que o homem enfrenta na vida quotidiana. Fazer arquitetura significa visualizar o genius loci: o papel do arquiteto é criar lugares significativos para ajudar o homem a habitá-los.

O genius loci é um conceito romano; de acordo com um credo antigo, cada ser independente tem seu genius, seu espírito guardião. Este espírito oferece vida aos povos e aos lugares, os acompanha desde o nascimento até a morte e determina seu caráter ou essência. Até os deuses têm seu genius, fato que explica a natureza fundamental da concepção. A finalidade existencial da edificação (arquitetura) é transformar um sítio em um lugar, ou seja, descobrir os significados potencialmente presentes no ambiente considerado. Seguindo esta mesma linha de pensamento, pode-se dizer que a forma urbana é intrinsecamente conectada ao caráter da cidade e ao seu genius loci.

"A estrutura de um lugar não é uma condição fixa, eterna; geralmente os lugares mudam e às vezes mudam rapidamente. Isto não significa que o genius loci deva ser modificado ou perdido" (NORBERG-SCHULZ, 2003, p. 18).

Continuando com o ponto de vista de Argan e de outros historiadores e urbanistas já citados, sobre a importância da história para a cidade contemporânea, a única continuidade, a rigor, o único desenvolvimento histórico é dado pela transmissão de certos significados através de certos signos arquitetônicos; mais exatamente, pelos diversos significados que, em épocas sucessivas, foram atribuídos a esses signos. Não importa se uma cidade tem uma história mais recente. A história é um fato eminentemente urbano, e sua relação com a cidade é muito estreita, embora não seja importante se sua história é mais recente ou secular. 
Depois da Segunda Guerra Mundial, os lugares na Europa sofreram profundas mudanças. Como diz Schulz, "nas cidades o tecido urbano ficou 'dilacerado', a continuidade dos muros que delimitavam as cidades foi interrompida, e a coerência dos espaços urbanos, deteriorada" (NORBERGSCHULZ, 2003, p. 189). Assim sendo, traçados viários, redes de infraestrutura, nós de comunicação, margens de rios e lagos, grandes acessos, perderam sua identidade e a cidade não é mais uma totalidade configurável.

\begin{abstract}
Mutações, transformações, simples alterações, têm, portanto, tempos diferentes; fenômenos particulares, acidentais como as guerras ou as expropriações, podem alterar em pouco tempo situações urbanas que pareciam definitivas, ou então estas mudanças podem acontecer em tempos mais longos devido a mudanças sucessivas e transformações pontuais. Em todas estas modificações, atuam muitas forças relativas à cidade, que podem ser de natureza econômica, política, entre outras (ROSSI, 1978, p. 189).
\end{abstract}

Em sua fase inicial, a indústria se instalou nas grandes cidades ou em suas imediações, dando lugar a fluxos migratórios que multiplicaram em até dez vezes a população urbana e praticamente destruíram a coesão das comunidades urbanas tradicionais. "Multiplicou-se, portanto, a quantidade e, paralelamente, degradou-se a qualidade urbana" (ARGAN, 1993, p. 78). A mobilidade oferecida pelo automóvel permitiu a muitas famílias adequar o próprio espaço de moradia à sua condição social, ou seja, residir em áreas distantes do centro da cidade ou em fragmentos de cidade dispersos pelo campo.

Por muito tempo, a melhoria das técnicas de transporte foi considerada como a maior responsável pela concentração urbana e industrial; foi responsável pelo distanciamento das indústrias das fontes de matéria prima e 
por sua proximidade com os mercados. $O$ transporte foi também, em boa parte, responsável pela destruição da pequena indústria local, desenvolvida em muitas regiões na época pré-moderna e durante as primeiras fases da modernidade.

Ao redor dos centros históricos, conservados apenas em parte, cresceram, sem outro princípio, a não ser a máxima densidade de população, enormes periferias superpopulosas; e "como a especulação tende à exploração total dos solos, não é raro as periferias estarem pouco dotadas de serviços, pesando, portanto sobre as frágeis estruturas do centro" (ARGAN, 1993, p. 257).

Em uma escala mais ampla, o arquiteto deve recuperar conceitualmente e fisicamente aquele diálogo entre espaço e indivíduo que caracterizou a história, desde a ágora grega ao fórum romano, às perspectivas espaciais das ruas renascentistas às propostas visionárias de Charles Fourier ou Claude N. Ledoux do lluminismo. Deve-se dar um significado mais amplo aos lugares funcionais para que permitam, hoje, aos indivíduos, uma aproximação físicaperceptiva à nova intervenção. É importante que as intervenções tenham a capacidade de interligar - mas não mimetizar - a própria arquitetura com o entorno, abandonando qualquer forma de se salientar ou, no máximo, considerando a edificação como fator caracterizante de um processo de reconhecimento do lugar e não relacionado com a capacidade do arquiteto.

Construir uma cidade não coincide só com o ato de erguer um ou vários edifícios, nem da combinação entre a definição de objetos físicos - o cheio - e sua composição com intervalos - o vazio. A cidade resulta das relações que 
cada elemento estabelece com os outros, mesmo e principalmente com aqueles imateriais.

Nesse sentido, Argan afirma que

a cidade é o produto de toda uma história que se cristaliza e se manifesta. $O$ que interessa são suas mudanças no tempo e essas mudanças não obedecem a leis evolutivas, são o efeito de um antagonismo entre vontade inovadora e tendências conservadoras (ARGAN, 1993, p. 244). 


\section{A Importância dos Traçados Históricos}

O saber científico age no passado por meio da seleção e eliminação, enquanto as ciências humanas estão mais ligadas à seleção para se obter a recuperação (RUSSO, 1998, p. 75).

Ao desenvolver a relação entre história e contemporaneidade, arquitetura e arte, o conceito de "centro histórico" pode ter uma utilidade pragmática, mas é um falso conceito. Na compreensão de Argan sobre a cidade, ela é in toto (em seu total) uma construção histórica onde a divisão da cidade em partes "históricas" e "não-históricas" não existe.

As próprias deformações e malformações urbanas devidas à gestão capitalistas são fatos, apesar de não gloriosos, da história de nossa época. Mas também está obviamente incluída na história de nossa época a tentativa de mudar a gestão da cidade e o sistema no qual se enquadra (ARGAN, 1993, p. 260).

A partir do IV congresso do CIAM (Congresso Internacional de Arquitetura Moderna), em 1933, e as conseqüentes resoluções fixadas na Carta de Atenas, dedicadas à cidade funcional, a atenção sobre a concepção do espaço na modernidade destacava a necessidade da separação das funções, da separação do tráfego de pedestres daquele destinado à circulação de automóveis, a concepção da cidade como organismo dinâmico e a sua conseqüente estruturação de modo flexível.

A Carta de Atenas (CIAM, 1933) ao se referir ao Patrimônio Histórico (item $\left.\mathrm{n}^{\circ} 65\right)$ apontava como necessidade primária inventariar os monumentos históricos dos vários países e estender o conceito de respeito, manutenção e 
salvaguarda da fisionomia da cidade, especialmente em torno dos monumentos propriamente ditos, assim como assegurar a preservação de certas perspectivas.

Por outro lado, a Carta de Atenas, que por 20 anos definiu amplamente o objeto da prática arquitetônica moderna, foi e continua sendo um dos manifestos mais contestados e míticos do movimento moderno. Mesmo Bernard Huet, no texto que escreve para a revista Lótus, em 1984, sobre a Carta de Atenas, observa que

enquanto a cidade histórica é totalmente percorrida por uma rede de hierarquias simbólicas nas quais o contexto e elementos emergentes, habitação e monumentos se confrontam, se contrapõem ou se associam para produzir significados e diferenças, o modelo proposto pela Carta, ao suprimir esta dialética da habitação, torna-se monumento. Não um instrumento de monumentalidade destinado a exaltar determinados valores coletivos, mas um monumento em si, tipo Unidade de Habitação de Marselha.

Observa-se, então, que as primeiras manifestações arquitetônicas do Movimento Moderno se limitavam a isolar os fenômenos e miravam uma

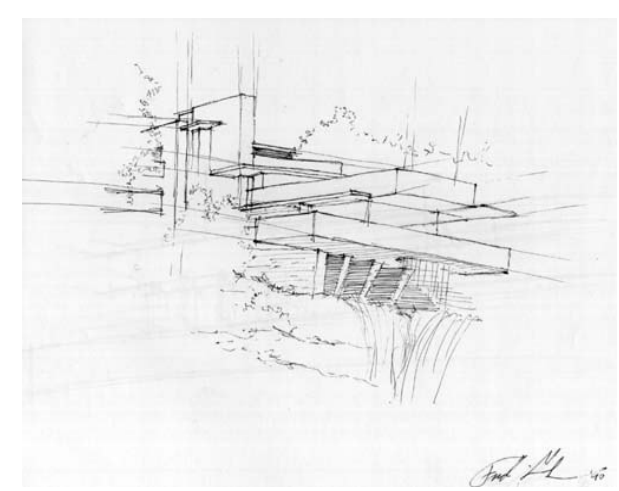

Fig.10 - F.L. Wright, Casa da Cascata objetividade de expressão que representasse cada produto artístico por si próprio, nos limites autônomos de sua existência individual. Até F. L. Wright e Le Corbusier, apesar de sensibilizados às sugestões do "ambiente natural" (o primeiro tentando confundir-se nele de acordo o gosto romântico; o outro, opondo-se, segundo uma concepção clássica), não tiveram por muito tempo nem ocasião, nem desejo, portanto nem consciência, de possíveis relações com um "ambiente 
cultural". "Os próprios desenhos urbanísticos, mesmo estendendo a espacialidade das áreas de influência, resultaram em visões autóctones de respeito à realidade histórica precedente, indiferentes e até mesmo adversas a ela" (ROGERS, 1958, p. 306).

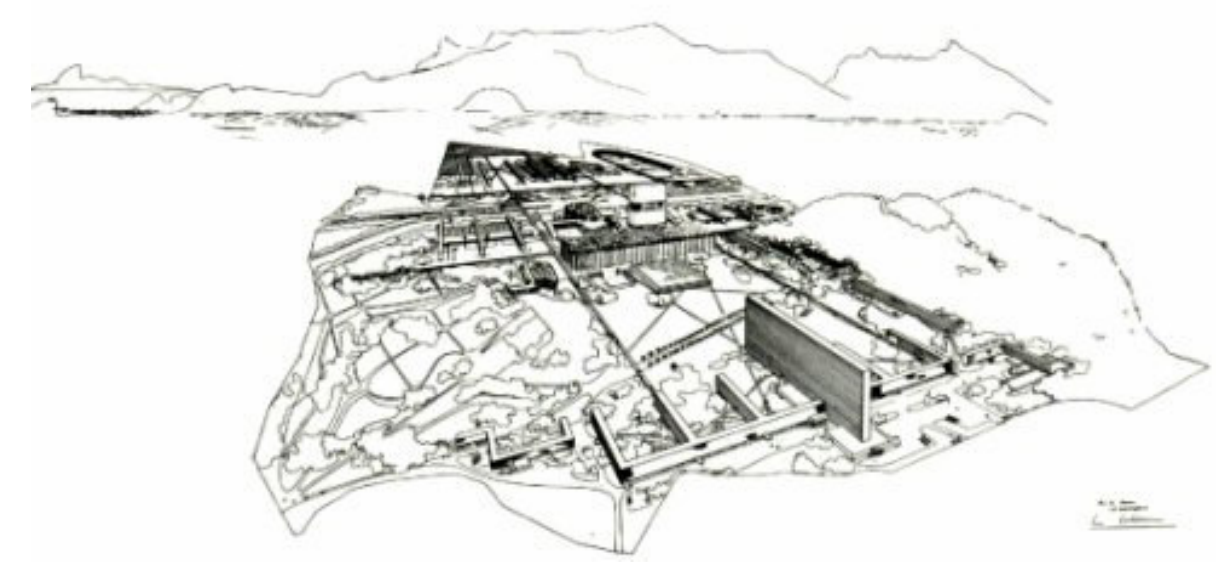

Fig. 11 - Proposta de Le Corbusier para a Universidade do Brasil, no Rio de Janeiro, 1937.

Ser moderno significa simplesmente sentir a história contemporânea como uma continuidade cuja própria colaboração aumenta e enriquece as atuais possíveis combinações formais de relações universais. Ernesto $\mathrm{N}$. Rogers, em 1945 dizia que construir um edifício em um ambiente já caracterizado pelas obras de outros artistas impõe a obrigação de respeitar essas presenças, levando a própria energia como um novo alimento para a perpetuação do pré-existente.

A construção de uma nova obra só pode se realizar com um ato criativo, mas este ato não pode ser insensato. "É preciso lembrar que os primeiros mestres do Movimento Moderno se consideravam precursores" (ROGERS, 1958 , p. 308), mas sabemos agora que existiam outras vanguardas. 
ser completo se não tiver uma interpretação pessoal dos dados objetivos" (ROGERS, 1958, p. 308).

E. N. Rogers afirmava que recopiar formas tradicionais era impossível, mas, somente o desenho de uma arquitetura, que resultasse apenas satisfatório ao nosso gosto e às condições da técnica contemporânea, não poderia ser suficiente se o caráter e as necessidades práticas não fossem interpretadas.

De acordo com todas essas definições, alguns dos temas aqui discutidos, principalmente aqueles relativos à história, ao centro histórico, à função e à permanência, devem ser considerados como bastante significativos. Embora esses temas mereçam um desenvolvimento particular, pretende-se aqui apenas delinear o esquema da história na arquitetura da cidade, abordando algumas implicações nas relações entre os indivíduos.

É provável que o valor da história como memória coletiva, entendida portanto como relação da coletividade com o lugar e com a idéia desse lugar, nos ajude a compreender o significado da estrutura urbana, de sua individualidade e da arquitetura da cidade que é a forma dessa individualidade.

Por pouco importante que tenha sido o pós-modernismo, algumas idéias desenvolvidas tanto por seus seguidores ou por seus críticos, deixaram indiretamente marcas significativas na continuidade do pensamento urbano e arquitetônico contemporâneo.

David Harvey, em seu livro Condição Pós-Moderna cita Krier como sendo um dos pós-modernistas europeus que busca - entre outras direções cultivadas pelos pós-modernistas, 
a restauração e a recriação ativas dos valores urbanos 'clássicos' tradicionais. O que significa a restauração de um tecido urbano mais antigo e a sua reabilitação para novos usos e a criação de novos espaços que exprimam as visões tradicionais com todo o avanço que as tecnologias e materiais modernos permitam (HARVEY, 1989, p. 70).

É importante não confundir esta postura nostálgica de citações históricas, pós-modernista, com a postura historicista que reivindica um papel crítico e interpretativo da história. Os pós-modernistas apenas acenam para a legitimidade histórica por meio de uma "extensa e muitas vezes eclética citação de estilos passados" (HARVEY, 1989, p. 85). O pós-modernista, de acordo com a definição de Harvey (1989, p. 69), "cultiva um conceito do tecido urbano como algo necessariamente fragmentado, um 'palimpsesto' de formas passadas, superpostas, e uma 'colagem' de usos correntes, muitos dos quais podem ser efêmeros".

Os pós-modernistas, além de atender a "impulsos nostálgicos", mantêm concepções radicalmente diferentes sobre o espaço enquanto os modernistas o vêem como algo a ser moldado para propósitos sociais e, portanto, sempre subserviente à construção de um projeto social. Já os pós-modernistas vêem o espaço como coisa independente e autônoma a ser moldada segundo objetivos e princípios estéticos sem necessariamente nenhuma relação com algum objetivo social abrangente, salvo talvez, a atemporalidade e a beleza "desinteressada" como fins em si mesmas.

A cidade contemporânea, ao contrário da cidade antiga e mesmo da moderna, está sujeita a mudanças múltiplas, rápidas e mesmo transitórias, portanto não permite propor modelos cuja referência seja estável, a não ser 
como fragmentos de cidade e fragmentos de um projeto arquitetônico. "Lugar da diversificação de atividades e mescla de pessoas, a cidade contemporânea é, por natureza, instável; sede de mudanças contínuas que provocam formação de situações críticas e soluções transitórias dos problemas: casas que viram fábricas, fábricas que viram teatros, escolas que viram casas, jardins que viram parques, ruas tranqüilas que viram eixos de tráfego intenso". (SECCHI, 2000, p. 80).

Mesmo hoje, ao projetar a cidade contemporânea, não se pode deixar de introduzir múltiplas funções, pensando da mesma maneira os elementos tipicamente urbanos e elementos arquitetônicos, a tal ponto que, mesmo as infra-estruturas possam ser imaginadas como espaços "habitáveis" e não mono-funcionais (grandes e complexas avenidas, viadutos, pontes). A residência permanece sempre o elemento capaz de exprimir e resumir, também do ponto de vista simbólico, os caracteres fundamentais da cultura de um povo.

Aldo Rossi (1966) afirma que uma parte da cidade constituir uma outra cidade no seu interior, não significa contestar um outro aspecto da teoria funcionalista, aquele do "zoneamento". Em contraposição, para Secchi, ao expressar-se sobre a cidade contemporânea, adverte sobre a dissolução e interpretação de alguns conceitos. Ou seja, dissolve-se o conceito de função na diversidade de atividades e sujeitos que caracterizam a cidade contemporânea; com o multiplicar de situações diversas, dissolve-se o conceito de zoneamento e hierarquia, de densidade e proximidade. 
$\mathrm{Na}$ visão moderna, decorrente da cidade industrial européia, o espaço público reduz sua intensidade de participação na medida em que a cidade amplia seu território. Aqui coincide com a trama das ruas e praças da cidade.

A cidade contemporânea, porém, substituiu os lugares tradicionais da sociabilidade por outros lugares ainda em via de progressiva definição funcional e formal.

\begin{abstract}
A fábrica ou o escritório onde os trabalhadores passam a maior parte da jornada, se torna, para a grande maioria da sociedade industrial, o verdadeiro lugar da integração social. Substitui a rua, o mercado e os lugares da sociabilidade tradicional (SECCHI, 2000, p. 91).
\end{abstract}

A rua tornou-se um espaço da sociedade contemporânea, que concentra edifícios ao invés de se configurar como espaço de convivência coletiva quotidiana. Todos os edifícios, contemporâneos e/ou vernaculares, têm uma fachada pública com uma função positiva ou negativa sobre o espaço público, capaz de enriquecê-lo ou empobrecê-lo. O conceito de interior privado do edifício se manifesta, em geral, na soleira que separa e une o interior com o exterior e confere à rua, a sua particular presença. Segundo Luis Khan, a rua é uma sala de espera... "[a] rua é dedicada à cidade por todo proprietário de uma casa..." (KHAN, 1974, p. 280).

Em Prima lezione di urbanistica (Primeira Lição de Urbanismo), Secchi escreve que na cidade moderna os principais equipamentos urbanos se tornaram lugares cada vez mais especializados e exclusivos: hospitais, escolas de todas as categorias e graus, teatros, ginásios esportivos, estádios, igrejas. Os equipamentos coletivos tornaram-se ilhas separadas do contexto urbano. 
Em muitos casos, mesmo em grandes pólos de atração de públicos específicos, não são mais lugares centrais como o foram nas cidades antigas, lugares de sua própria sociabilidade. "O que ainda hoje chamamos, graças à inércia da linguagem, de equipamento coletivo, antes era verdadeiramente espaço do público. Um espaço que se prolongava para o exterior do edifício, no átrio, na praça e no bairro".

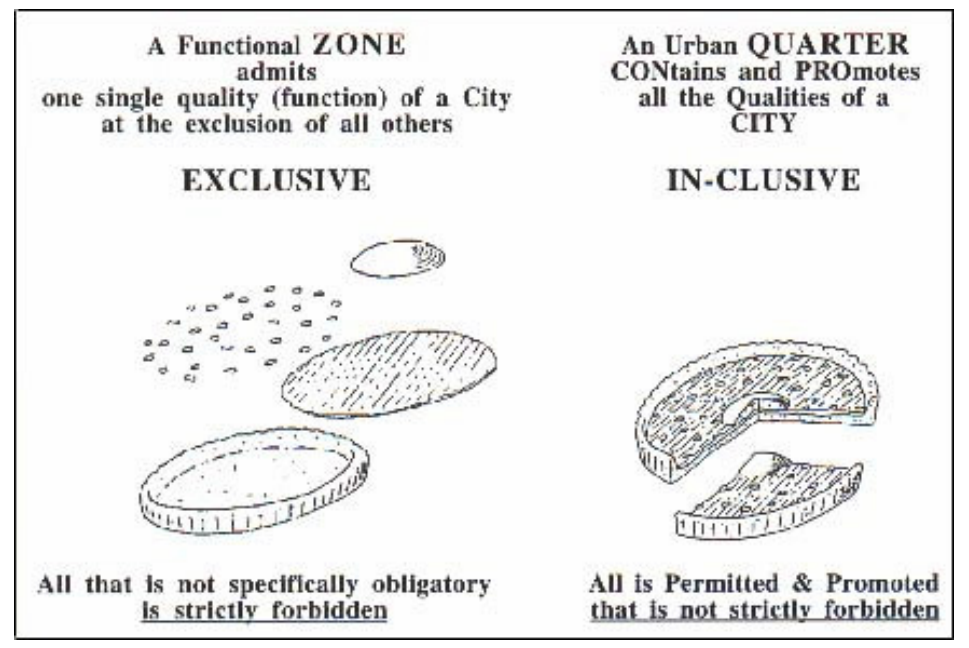

Fig. 12 - Léon Krier - carta para reconstrução da cidade européia.

Na Carta para a reconstrução da cidade européia, elaborada em 1985, Léon Krier afirma que uma cidade se articula em espaços públicos e espaços privados, monumentos e construções urbanas, arquitetura e edificações "exatamente nesta ordem". No entanto, somente uma grande complexidade funcional pode levar a uma articulação dos espaços, dos bairros urbanos e da cidade como sendo um conjunto legível, claro, satisfatório no tempo e bonito.

\section{Demarcações Territoriais: os Novos Conceitos de Espaço Público e Privado}

Os conceitos de "público" e "privado" podem ser interpretados como a 
tradução em termos espaciais de "coletivo" e "individual". (HERTZBERGER, 1996). Podemos dizer que "público" é a área acessível a todos, a qualquer momento; a responsabilidade por sua manutenção é assumida coletivamente. "Privado" é a área cujo acesso é determinado por um pequeno grupo ou por uma pessoa, que tem a responsabilidade de mantê-la.

Ao longo do tempo existiram diferentes conceitos de espaço público urbano. Jeff Weintraub ${ }^{2}$ define duas versões de espaço público na Europa: uma versão clássica de origem greco-romana uma visão moderna ligada à experiência secular e à pratica social na cidade multifuncional e compacta. $\mathrm{Na}$ concepção clássica, o espaço público de uma comunidade política está baseado na cidadania, na participação coletiva da tomada de decisões. Sua representação física e social é a pólis (autônoma, deliberativa, democrática). A vida social pública se identifica com a ágora, um espaço de discussão e confronto. Na visão moderna, decorrente da cidade industrial européia, o espaço público reduz sua intensidade de participação na medida em que a cidade amplia seu território. Aqui coincide com a trama das ruas e praças da cidade.

David Harvey define o conceito de espaço como "multidimensional", na medida em que possui um significado diferente de acordo com a formação cultural, a capacidade de percepção e o escopo científico. Se aceitarmos esse propósito "multidimensional", perceberemos que ele pode ser explícito em várias e apropriadas geometrias.

A cidade moderna propõe temas e problemas que, em combinações diversas, são reencontradas em todo lugar e que, portanto, podem tornar-se

\footnotetext{
${ }^{2}$ citado em LOPEZ DE LUCIO, 2000
} 
objeto de reflexões gerais enquanto não se encontram características idênticas nas cidades contemporâneas do mundo ocidental.

Mas, se faz necessário um breve esclarecimento sobre o que nos referimos quando falamos da cidade moderna e o que nos referimos quando falamos de cidade contemporânea, o que mudou e o que se conservou. A passagem de uma época para outra não é improvisada; cada forma desenvolvida contém, dentro de si mesma, resquícios da forma precedente e isto se verifica - em maior ou menor grau - em todas as épocas históricas.

Os arquitetos do Movimento Moderno preconizaram um novo modelo de cidade onde o espaço público deveria ser maior. Ele não se limitaria às ruas, avenidas e praças. Englobaria os edifícios residenciais, que não se fechariam em habitações, mas estariam inseridos em uma paisagem ilimitada e verde: é uma nova utopia de cidade integrada à natureza. Mas, o "fluir" contínuo de espaço, que mal distingue o interior do exterior, não pode se adaptar em uma situação urbana. De certa maneira, pode-se dizer que a ocupação urbana moderna é concebida como uma casa ampliada ao invés de lugar urbano. Na cidade, é fundamental uma clara distinção entre domínio público e domínio privado, o espaço não pode fluir sem essa diferença. A relação interno-externo, aspecto primário do espaço concreto, subentende que o espaço possui uma variedade de extensão e fechamento. Ou seja, ocupação e paisagem têm uma relação de figura e fundo. Segundo T. Hall (1968, p. 61), em La dimensione nascosta ${ }^{3}$ (A Dimensão Oculta), "a percepção espacial não compreende somente tudo o que é percebido mas também aquilo que é excluído".

\footnotetext{
${ }^{3}$ HALL, E. T.The Hidden Dimension. Garden City, N.Y.: Doubleday, 1966, edição original em ingles.
} 
Além do que, o estilo internacional estava atrelado às questões do homem-tipo (biologicamente idêntico independentemente de seus valores sociais e culturais) e, conseqüentemente, à habitação como "máquina de morar". Admitindo um modelo de homem universal, reduziu-se a vida urbana àquelas quatro funções básicas - habitação, lazer, trabalho e circulação - e ignoraram-se as condições específicas do local tanto em termos físicoambientais quanto sócio-culturais. Surgiram concepções de cidades baseadas em princípios formais e funcionais, com tendência a uma maior homogeneização dos espaços urbanos.

Segundo Gregotti, a complexidade funcional, isto é, a mistura de usos e atividades, é condição básica para que ocorra viabilidade de um espaço público urbano. Na cidade clássica, a sobreposição de habitação, comércio, serviços de base, equipamentos públicos e privados médios, pequenos escritórios, criam as condições corretas da complexidade funcional. As técnicas de zoneamento asseguram a uniformização funcional e social, reduzindo a complexidade urbana.

A cidade contemporânea parece, para muitos, um confuso amálgama de fragmentos heterogêneos, no qual não é possível reconhecer nenhuma ordem, nenhum princípio de racionalidade que a faça inteligível.

Por isso, tanto

a cidade contemporânea, como a antiga, é lugar privilegiado da miscigenação e da simultaneidade - de casas e oficinas, de escritórios e lojas, de equipamentos públicos e privados, de linguagens arquitetônicas, de culturas, figuras sociais, técnicas produtivas, produtos. Partes da cidade, materiais urbanos e formas espaciais pertencentes a diversos períodos da história mesclam-se a outros materiais, formas, figuras e técnicas que anunciam aspectos do futuro e da modernidade. Sede de mudanças contínuas que provocam formação de situações críticas e soluções transitórias dos 
problemas, a cidade contemporânea é por natureza instável: casas viram fábricas, fábricas viram teatros, escolas viram casas, jardins viram parques, ruas tranqüilas viram eixos de tráfego intenso (SECCHI, 2000, p. 80).

Entretanto, muitas dessas mudanças da cidade contemporânea têm suas raízes profundamente incrustadas na modernidade, ou, pelo menos, na sua última fase industrial.

Na cidade contemporânea, caracterizada cada vez mais pela economia e pelo consumismo, ocorre uma transformação radical dos modos como se produz espaço urbano e espaços públicos.

O espaço público e seu domínio, sua qualidade estética e o seu poder de socialização nunca foram o resultado de um acontecimento casual, mas de uma percepção e de uma vontade civil. Pois o espaço público urbano é o lugar privilegiado do exercício da cidadania e da expressão dos direitos civis: uma cidade que funciona exclusivamente com o automóvel, organizada em centros especializados e fechados, não facilita o progresso da cidadania tendendo à segmentação, individualismo e exclusão. De acordo com o pensamento de Marc Augé, o espaço descaracterizado, abstrato, que troca sua imobilidade por uma mobilidade virtual, passa a permitir que o corpo, graças a sua inerente mobilidade, o incorpore tornando-se uma estranha imagem onde seria figura e fundo de sua própria história. Alguns dos mais evidentes aspectos da cidade contemporânea - fragmentação, heterogeneidade e dispersão - têm sido muitas vezes atribuídos às numerosas e sucessivas ondas de progresso técnico ocorridas no campo das comunicações e do transporte. 
mesmo século, relaciona-se ao pleno desenvolvimento das redes ferroviárias e do telégrafo; o terceiro, na primeira metade do século $\mathrm{XX}$, liga-se ao desenvolvimento rodoviário e ao rádio; o quarto, na segunda metade do século passado, ao desenvolvimento da eletrônica e da telemática; e o quinto, que provavelmente se inicia agora, baseia-se na convergência desses desenvolvimentos tecnológicos, em complexas redes telemáticas e mecânicas (HALL, 1997 apud SECCHI, 2000, p. 83).

Ao mesmo tempo, a moderna revolução cibernética mudou definitivamente alguns dos parâmetros clássicos de socialização. Surgem os "não-lugares" repetidamente descritos por Augé em seu livro "Não-Lugares": as estradas de rodagem, os aeroportos, os grandes centros comerciais, compartilhados por milhões de pessoas, são exemplos mais evidentes, além de cinemas, estádios, aeroportos, discotecas, ginásios de esportes, parques de diversão. Lugares onde muito freqüentemente se sente certa nostalgia pelo passado, como no espaço para pedestres e climatizado do shopping center, organizado como o centro antigo de uma pequena cidade européia (AUGÉ, 1993).

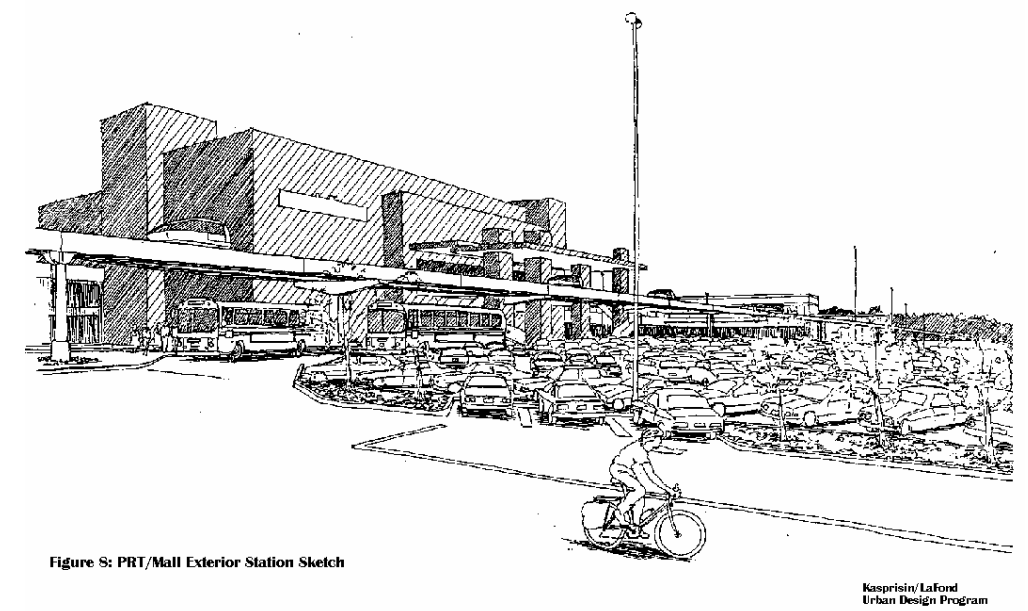

Fig. 13 - Desenho de um Shopping Center ou um "não-lugar"

Diferentemente destes "pseudo-espaços públicos", a utilização do espaço público convencional não está submetida a outras regras nem códigos 
de comportamento além daqueles de direito civil geral. As atividades lúdicas e políticas são permitidas (dentro de certos limites), sem que sejam submetidas aos imperativos do consumismo.

Esses novos equipamentos urbanos, em geral, não encontraram espaço dentro da cidade existente e de seu sistema de compatibilidade e incompatibilidade.

Graças à mobilidade permitida pelo automóvel e pelas novas técnicas de transporte coletivo embora não por sua causa, os novos equipamentos, compostos por hotéis, salas de congresso, ginásios e equipamentos esportivos - à semelhança da miscigenação e articulação da cidade antiga - acabam dispersos em um território imaginado cada vez mais como um grande campus, um parque de objetos e fragmentos da cidade, isolados e livremente dispostos no verde (SORKIN, 1992 apud SECCHI, 2000, p. 93).

Nesse sentido, como já observou o urbanista espanhol López de Lucio (2000), a falta de continuidade espacial do tecido urbano, provocada pela formação de áreas autônomas, segregadas entre si por estradas ou vazios, pode gerar uma sociedade desestruturada. Quando as escalas se tornam grandes demais ou a conservação e a administração de uma área comunitária não podem mais ser entregues àqueles que estão diretamente envolvidos nelas, tornando necessária uma organização especial, não é possível formar espaço público.

No mundo todo encontramos graduações de demarcação do território, acompanhadas pela sensação de acesso. Às vezes, o grau de acesso

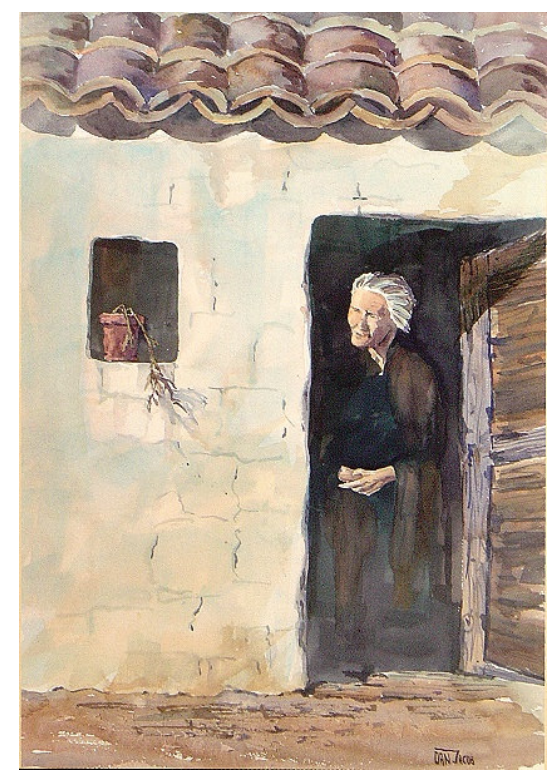

Fig. 14 - A soleira da porta 
é uma questão de legislação, mas em geral é exclusivamente uma convenção respeitada por todos. O conceito de intervalo é a chave para eliminar a divisão rígida entre áreas com diferentes demarcações territoriais.

Nos espaços intermediários, onde os moradores sentem-se mais inclinados a expandir sua esfera de influência em direção à área pública, a qualidade deste espaço será consideravelmente aprimorada no interesse comum. A soleira é tão importante para o contato social quanto as paredes grossas para a privacidade, lugar de encontro entre os vizinhos e de reconciliação entre a rua e o espaço privado (HERTZBERGER, 1996).

Por outro lado, é importante criar níveis mínimos de integração e coesão social entre a população. Não importa a magnificência dos projetos urbanos criados; se não existe coesão, não se pode assegurar a vitalidade do espaço público. A alternativa é a retração na privacidade, o ócio ou o consumo oferecidos pelo setor privado.

Sobre este aspecto, são interessantes os estudos do antropólogo americano Edward T. Hall sobre a proxêmica, que pode ser explicada como sendo uma técnica de leitura da espacialidade, como canal de comunicação.

A comunicação proxêmica constitui-se no jogo de distâncias e proximidades que se entrelaçam entre as pessoas e o espaço. Traduz

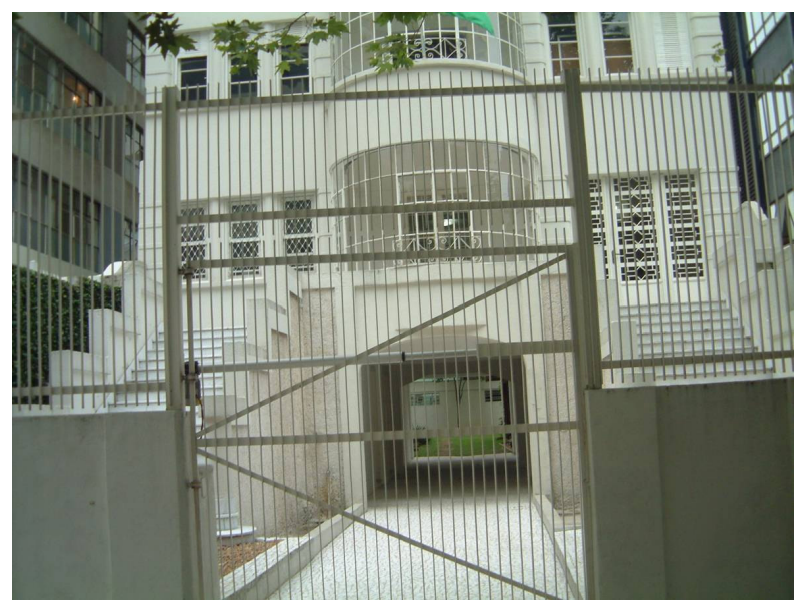

Fig. 15 - Espaço "público /semi-privado" de um edifício na rua Maranhão em S.P. as formas como nos colocamos e movemos uns em relação aos outros, como gerimos e ocupamos o nosso espaço envolvente. A relação que os 
comunicantes estabelecem entre si, a distância espacial entre eles, a orientação do corpo e do rosto, a forma como se tocam ou se evitam, o modo como dispõem e se posicionam entre os objetos e os espaços, permite-nos captar mensagens latentes.

A proxêmica nos ajuda a entender 0 significado de espaço. Não nos diz o quê, nos espaços abertos é necessário conservar ou destruir. Mas nos lembra que hoje, neste setor, estamos conservando ou

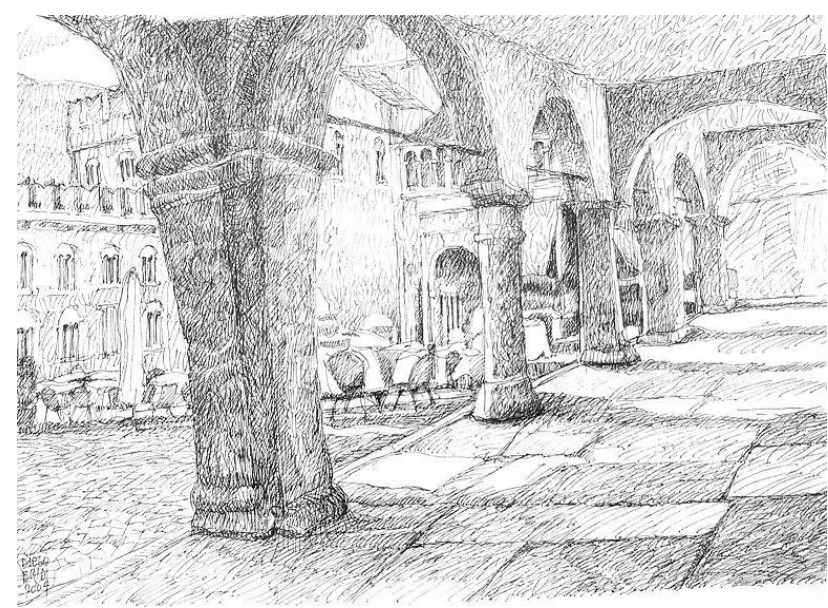
Fig. 16 - Espaço "intermediário": Pórticos na Itália destruindo, indiscriminadamente, algo que não conhecemos, algo que freqüentemente ignoramos o peso ou mesmo a existência. Como toda ciência, portanto nos oferece os argumentos para uma conscientização mais clara de nossa situação ${ }^{4}$.

Em última instância, o espaço público se reduz à habitação familiar, como afirma Javier Echevarria. Passear pelas ruas e praças da cidade não é mais necessário. O indivíduo se conecta na internet e participa virtualmente do mundo. Ou seja, a perspectiva do espaço público pós-moderno apresenta dois aspectos: na sua contração virtual dentro do âmbito de uma privacidade ligada à TV e ao PC, até uma concepção instrumental vazia de conteúdos sociais e degradada à redução dos "não-lugares". (ECHEVARRIA citado em LOPEZ DE LUCIO, 2000).

\footnotetext{
${ }^{4}$ V. o prefácio de Umberto Eco à tradução do livro The Hidden Dimension de E.T. Hall, para o italiano
} 
Para Marc Augé, se um lugar pode se definir como identificador, relacional e histórico - um espaço que não pode se caracterizar como possuidor de uma identidade, nem como relacional, nem como histórico, definirá um não-lugar.

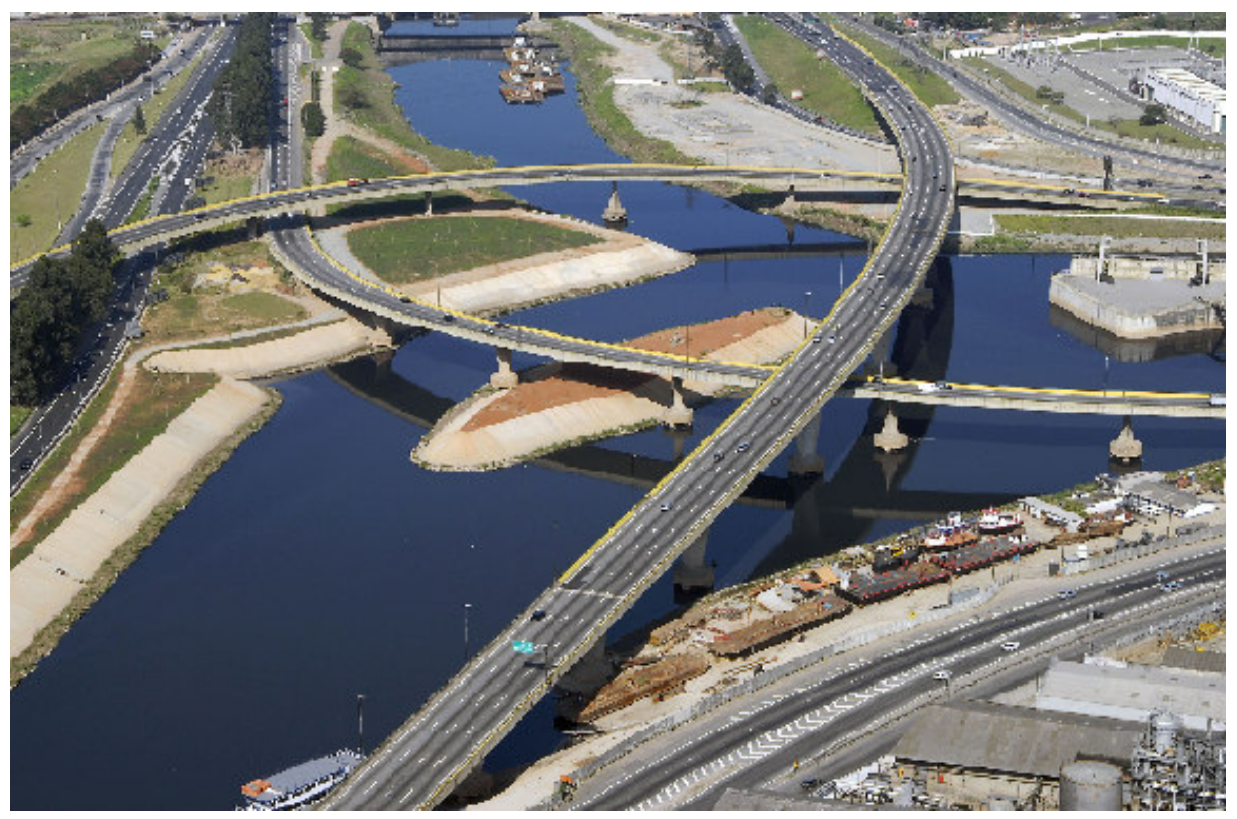

Fig. 17 - Um não-lugar: o Cebolão da Marginal Pinheiros /Marginal Tietê - SP

O espaço do não-lugar não gera nem identidade individual nem relação, mas sim solidão e similitude. Porém, os códigos e regras de comportamento nos não-lugares são iguais e isto oferece sensação de segurança ao indivíduo.

"O não-lugar é o contrário da utopia: ele existe e não abriga nenhuma sociedade orgânica" (AUGÉ, 1992, p. 101).

\section{As Relações Existentes entre o Edifício Construído e a Cidade}

Como foi visto, ao estudar uma determinada realidade em um contexto específico, como um edifício, um espaço vazio, uma área verde, tentou-se 
analisar não somente suas componentes presentes e visíveis, mas procuramos também individuar os vestígios, os sinais, as regras, as estratificações, as seqüências, as ações e retroações que são sobrepostas e entrecruzadas no espaço e no tempo. Ao interpretar e selecionar os diversos momentos, descobrimos articulações ocultas: interrupções ou potenciais solicitados que utilizamos como instrumentos e ocasiões para revelar a trama complexa dos signos e das relações entre as condições atuais e as suas origens mais distantes. Operando nas periferias, deveríamos agir do mesmo modo, pesquisar a integridade dos fragmentos do território não ocupado, os vazios, as margens e os resíduos; interpretá-los como última fase de um longo processo de sedimentação e sinal da estrutura histórica e natural muito variada, freqüentemente relacionada à cidade, cuja fundação e construção não é somente a materialização física de um modelo teórico espacial e social, mas também, em muitos casos, a extensão das características morfológicas e naturais de um lugar, a priori, selecionado.

Que sentimento da cidade pode ter ou conservar o operário que vive em periferias? Ir ao centro é para ele uma façanha, como era outrora "ir à cidade" para os habitantes do vilarejo; e é no mínimo curioso que, cada vez que se fala em sociedade e em comunidade, se excluam os operários, relegando-o aos subúrbios periféricos, justamente aqueles que, além de "constituir a parte numericamente maior da população, são os protagonistas mais diretos da chamada 'função urbana'” (ARGAN, 1993, p. 230-231). "Distanciar e separar: 0 grande paradigma sobre o qual, a partir do século XVIII, se construiu a cidade moderna" (SECCHI, 2000, p. 80). 
$\mathrm{Na}$ cidade, todos os edifícios, sem exclusão, são representativos e com freqüência, identificam as malformações, as contradições, as vergonhas da comunidade.

É o caso da péssima qualidade arquitetônica que a especulação descontrolada acumulou nas cidades e a cujo respeito se diz com demasiada freqüência que não são arquitetura - mas são, e são arquiteturas representativas de uma infeliz realidade social e política (ARGAN, 1993, p. 243).

As condições físicas de um ambiente, praças, pátios, ruas, áreas verdes, favorecerem ou inibem o desenvolvimento de relações humanas. Ficou demonstrado que, quando o espaço resulta de baixa qualidade, ele acaba por receber somente atividades necessárias, indispensáveis ou obrigatórias, como caminhos, escola, trabalho, supermercados; pequenas atividades que prevêem percursos realizados a pé, que se desenvolvem durante $o$ ano inteiro e em qualquer condição física ou climática. Segundo Argan tudo o que não funciona na cidade, reflete, em ultima análise, os defeitos da cultura arquitetônica ou revela sua incapacidade de preencher suas funções institucionais. Quando, ao contrário, o ambiente se revela de alta qualidade, fornecendo uma ampla gama de oportunidades e estímulos, as atividades necessárias se desenvolvem com a mesma freqüência, mas logo surgem outras espontaneamente, se o lugar favorece: passear, praticar esportes, comprar, sentar, falar conversar, brincar, observar (ARGAN, 1993 p. 243).

O desenvolvimento da identidade individual e social é um processo lento que não se pode verificar em um ambiente em contínua mudança. Schulz acredita que a alienação hodierna seja devida, em grande parte, às escassas possibilidades de orientação e de identificação oferecidas pelo ambiente 
contemporâneo. As pesquisas de Piaget de fato demonstram que o mundo em movimento manteria o homem em um estágio egocêntrico de desenvolvimento, enquanto um mundo estável e estruturado liberaria suas faculdades mentais (NORBERG-SCHULZ, 2003).

Normalmente é na cidade onde a vontade inovadora e as tendências conservadoras se enfrentam. Quem defende história e tradição urbana e quem trata a cidade como um deserto para se colocar objetos de design se insere num debate que não ocorre só na Itália ou na Europa, onde o percurso da história é longo. É um debate em arquitetura. Mesmo com menor força, ele ocorre em todas as cidades contemporâneas. Como dizia Rossi (1978, p. 179), a ligação entre o passado e o futuro está para a cidade assim como a memória está para a vida de uma pessoa. Esta realidade permanece nos seus fatos históricos pontuais, nos seus monumentos, na idéia que temos deles; isto explica também por que a antiguidade tinha o mito como fundamento da cidade.

Assim, o objeto arquitetônico assumiu uma autonomia técnica e formal que antes era desconhecida; uma liberdade que destruiu gramáticas e sintaxes, hierarquias e ordens precedentes. O conflito entre quem invoca 0 respeito do genius loci, da cidade como tecido a ser respeitado, contra a arquitetura como imagem indiferente aos lugares, ou seja, a dos não-lugares.

Ao definir o conceito de "não-lugar", Marc Augé sustenta que o não lugar pode gerar temores e insegurança emocional, pois não existe possibilidade de identificação e a carência de estímulos induz a uma certa passividade, reduzindo a capacidade intelectual. Mas sem chegar a tanto, "a verdadeira crise da cidade manifesta-se não apenas em uma diminuição do seu nível 
cultural, mas também na perda do seu caráter original de organismo cultural" (ARGAN, 1993, p. 257).

A cidade contemporânea é o lugar de destruição de consolidados sistemas de valores simbólicos e monetários, de novos lugares de comércio, de lazer, da comunicação e interação social, de uma nova geografia de centralidades. Isso e outros valores, com a progressiva uniformização e democratização do espaço urbano, determinam, segundo Secchi (2000, p. 82),

\begin{abstract}
uma instabilidade na cidade contemporânea, pois dão origem a um contínuo deslocamento e reorganização das diversas atividades, a obsolescência, os fenômenos de degradação e filtering-down, cujas conseqüentes ações de reutilização, recuperação e o up-grading de partes limitadas e circunscritas da cidade se apresentam ao indivíduo como um sistema caótico.
\end{abstract}

Não se pode esquecer que as cidades são "bens culturais" em seu conjunto e que, portanto, é inútil sanear bairros antigos se não se procura, ao mesmo tempo, Ihes restituir uma função que não seja artificial. (ARGAN, 1993, p. 249).

A universalização da cultura, o difundir dos símbolos comuns, o progresso tecnológico e o acesso cada vez maior dos meios de transporte para grandes distâncias, torna hoje, no nosso modelo de cultura, os homens bem mais indiferentes ao ambiente urbano e territorial de origem ou atenua a relação entre ambiente físico e a cultura dos grupos sociais. (GREGOTTI, 1977, p. 68).

No reconhecimento - que se deve a Venturi - de a arquitetura ser o muro que divide o interior do exterior, pode-se afirmar que na cidade contemporânea, com o desaparecimento da estrutura urbana tradicional, os 
percursos e as praças urbanas são definidos por edifícios que incorporam os significados reunidos pela cidade (VENTURI, 1980).

O espaço urbano é um vazio, um vazio estruturado e estruturador. Ele tem uma hierarquia, dimensões e caráter, não pode ser simplesmente uma conseqüência casual do construir. Muitas vezes é um espaço desperdiçado, um falso luxo e, em pequenas quantidades, uma falsa economia.

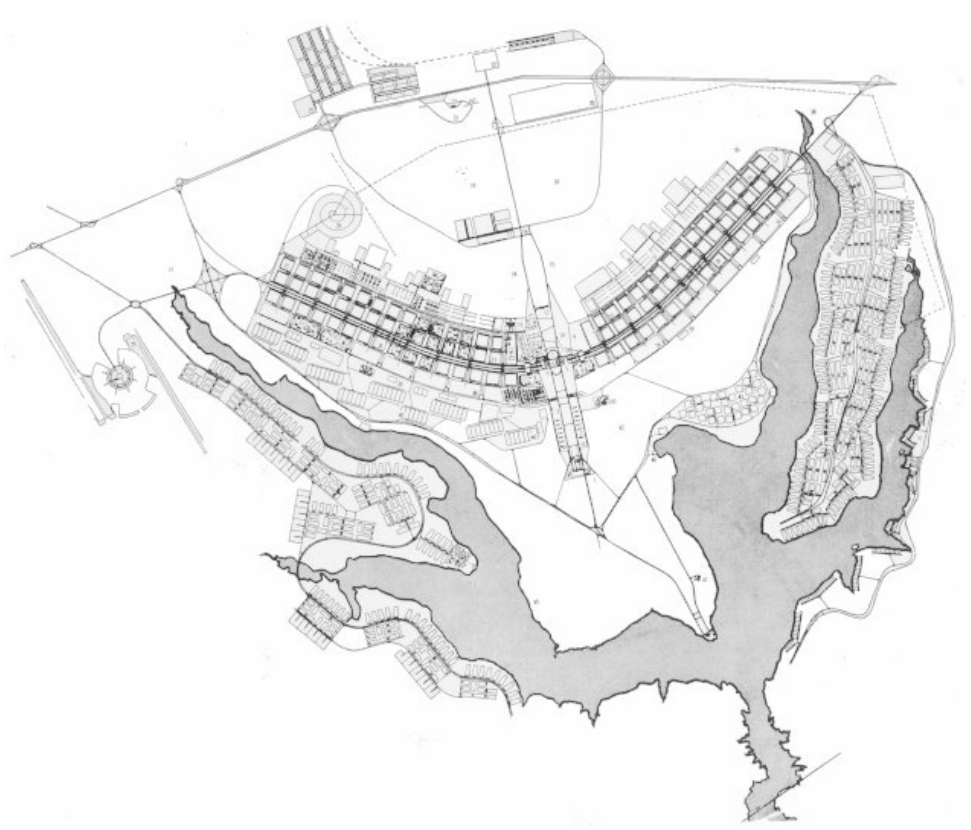

Fig. 18 - Brasília - Desenho do plano piloto.

Naturalmente, estamos conscientes de que

a realidade territorial é formada por uma série de estratos bem complexos e interagentes que se constituem em modelos espaciais diferenciados (geográficos, administrativos, demográficos, econômicos, etc). E devem ser organizadas entre si tendo um objetivo comum que se concretizará em uma nova forma do território. (Gregotti, 1977, p. 79). 


\title{
3. Arquitetura Vernacular e Espaço Metavernacular
}

\begin{abstract}
A cidade, como objeto humano por excelência, é constituída por sua arquitetura e por todas aquelas obras que constituem o real modo de transformação da natureza (ROSSI, 1978, p. 30).
\end{abstract}

A cidade contemporânea, e não só a européia, é composta de vários estratos, um palimpsesto, uma paisagem formada por edificações construídas em fases e tempos diferentes do crescimento urbano. Em cada época, cada sociedade se diversifica da que a precedeu, por meio de sua própria representação nos monumentos arquitetônicos, tentando o impossível - marcar aquele momento determinado - além das necessidades e dos motivos contingentes pelos quais os edifícios foram construídos. Além disso, cada indivíduo no decorrer do quotidiano deixa um sinal no próprio ambiente urbano e, dessa maneira, contribui na definição das características daquele espaço.

Nas relações entre as várias partes e a sua forma geral, a cidade é totalmente percorrida por uma rede de hierarquias simbólicas nas quais 0 contexto e os elementos emergentes como habitações e monumentos se confrontam, se contrapõem ou se associam para produzir significados e diferenças.

Em seu livro // significato delle città (O Significado das Cidades), Carlo Aymonino observa que o patrimônio edificado apresenta massa construída, configuração espacial, relação entre volume edificado e vazio, ritmo, cores e inserção na paisagem urbana ou natural. A individualidade e, portanto, 0 reconhecimento de cada elemento, se compõe para criar um conjunto cujos 
fundamentos estão exatamente na coerência das partes em relação ao todo. Dessa maneira, a história urbana se delineia imediatamente como história das construções, do espaço físico, uma história que aborda como as formas e os modos de vida se adaptaram, pois o espaço possui uma memória infinitesimal em que nada escapa.

Independente do motivo pelo qual certos edifícios ou monumentos arquitetônicos foram construídos, a cidade quer fixar, marcar aquele tempo determinado, que é sempre diferente daquele que o substituiu, tornando-se uma herança que testemunha aspirações pessoais ou coletivas. "A beleza de uma cidade, o seu poder de ser 'arte', é um dado próprio pela contradição existente entre o tema inicial (o motivo pelo qual surgiu o monumento) e a realidade continuamente mutável pelo uso que se faz de tal herança" (AYMONINO, 2000, p. 18).

Recuperar a dialética da unidade e do fragmento, do contínuo e do descontínuo, do idêntico e do diverso significa aceitar um espaço urbano carregado de valores simbólicos hierarquizados que dão um significado diferencial à arquitetura. Hoje, é necessário se adaptar a cada situação e reinventar soluções.

Aymonino ressalta não haver dúvidas de que a relação de diferenciação das várias partes constituintes de uma cidade - em relação a uma definição arquitetônica - tenha constituído ou constitua ainda o elemento dialético fundamental do desenvolvimento de uma cidade sob o aspecto da arquitetura. E que é exatamente a mudança das relações, seja como substituição, seja como sobreposição de mais épocas, que determina a individualização de uma cidade em relação à outra e sua possível aceitação como "obra de arte". 
A história não se manifesta apenas na materialidade da cidade e sim na sua imaterialidade: na cultura, na memória humana e em muitos outros modos não relacionados à conservação patrimonial.

Porém, como observou Aldo Rossi (1978), é costume transformar monumentos, edifícios e espaços particulares, tornando-os lugares da memória coletiva, símbolos imutáveis em um mundo mutável. No entanto, os modelos urbanos do passado não são capazes de abrigar todas as complexas relações contemporâneas. Muitas vezes, em nome do moderno e do progresso tende-se a um rompimento com o passado, com o antigo e com tudo aquilo que se identifica com ele.

Mas não é suficiente. Os urbanistas tentam dar forma, estrutura e coesão aos elementos urbanos; os arquitetos, por meio de obras de edificação, ultrapassam a marcação do tempo, enquanto a arquitetura vernacular, mais espontânea, revela e interliga sua historicidade à tradição, dando caráter ou genius loci à cidade. "A arquitetura não se constrói só com purezas, mas também com contaminações", admite o arquiteto e teórico italiano, contemporâneo, Daniele Vitale ${ }^{5}$, explicando o patrimônio vernacular e sua continuidade, tanto em relação aos significados que os traçados do passado assumem em relação às novas exigências, como às novas formas da vida urbana.

A arquitetura vernacular - entendida como arquitetura comum, anônima, construída sem interferência de arquitetos ou engenheiros - constitui a fisionomia da cidade, ou seja, é aquela que se exprime com linguagens e expressões que refletem o lugar e o ambiente onde foi formada. Uma cidade

\footnotetext{
${ }^{5}$ Em conferência proferida na Faculdade de Arquitetura e Urbanismo da USP em 2004.
} 
nunca é igual à outra; as cidades resultam de uma infinidade de diferenças geográficas ou da tradição. A arquitetura vernacular é uma das chaves para se poder entender o genius loci de uma cidade. Talvez por essa arquitetura geralmente se mostrar modesta, muitas vezes uma simples cabana, não consegue obter o valor necessário; todavia, apenas a sua grande diversidade poderia ser argumento interessante a ser aprofundado.

Isto reforça o conceito de que a arquitetura vernacular somente deve ser considerada dentro do seu contexto, como uma ponte entre a história e a arquitetura, como um sistema contínuo de referências para a transformação e tutela dos valores históricos e culturais e para a formação de uma consciência popular.

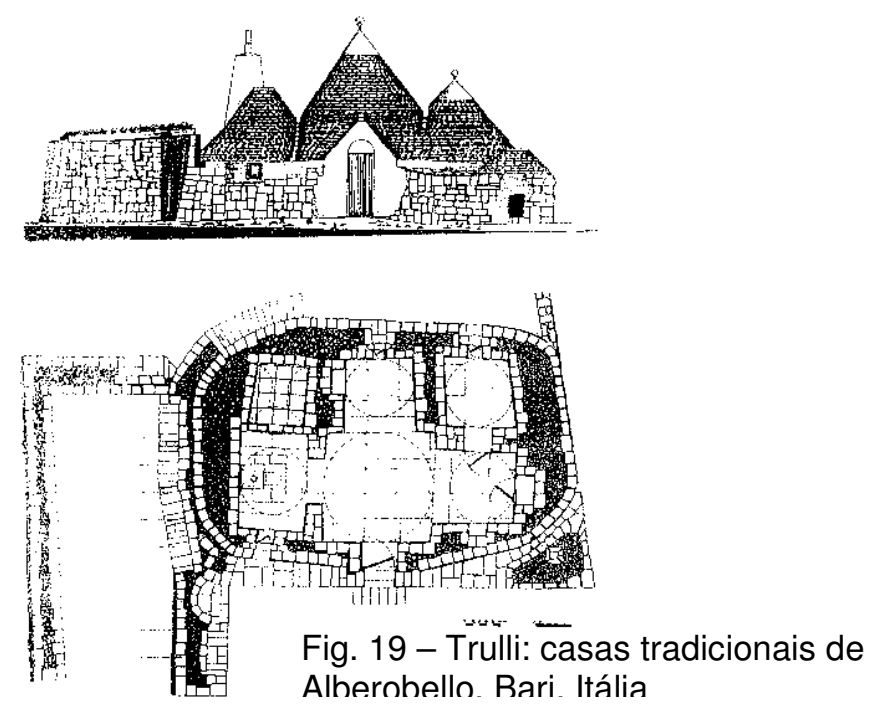

Visto que muitos edifícios sobrevivem à sua função, transformá-los é, e continuará a ser, uma ação importante. O monumento, testemunho sóciocultural de um determinado período histórico, explica a sua função de memória e ensinamento histórico somente se pertence à comunidade. Qualquer obra de arte não accessível a todos perde seu valor histórico. Do mesmo modo como é importante transformá-los fisicamente, é importante analisar o conceito e 
aprofundar seu fundamento lógico. A sua longevidade deve-se a uma constante redistribuição de conhecimento duramente conquistado. Diferente das artes e da arquitetura dos monumentos, a vernacular nunca seguiu caprichos e modismos; evoluiu no tempo de maneira quase imperceptível, adaptando-se às dimensões e necessidades humanas sem grandes apetrechos ou elementos supérfluos.

Mas, a partir do momento que um "estilo" foi fixado, criando assim tradições na arte de construir habitações, mudar pelo simples fato de mudar é totalmente impensável e, em alguns lugares, a utilização exclusiva de materiais de construção locais garante o perdurar de métodos construtivos já experimentados ao longo do tempo. Quando são introduzidos materiais e métodos novos, as tradições locais se dissolvem, as novas tendências aparecem e o vernáculo se perde.

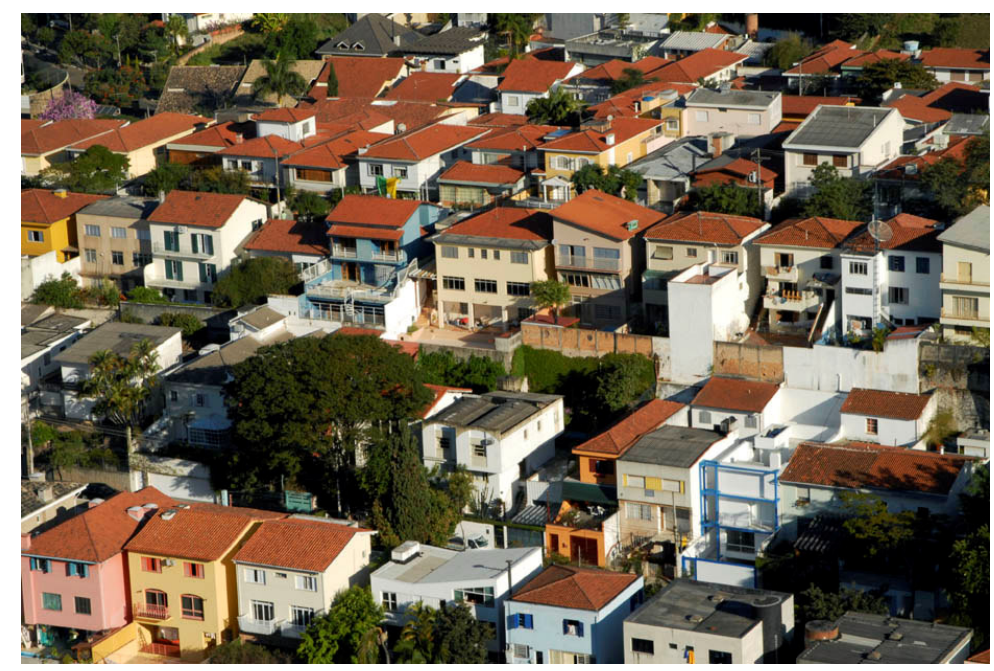

Fiq. 20 - Sobrados em Perdizes, São Paulo

$\mathrm{Na}$ arquitetura vernacular a inovação não é considerada uma virtude.

Nela, não são reconhecidos estilos, mas somente um único estilo que é fixo e imutável na sua essencialidade tipológica e morfológica, da mesma maneira como o são os objetos na natureza e, como na natureza, as realizações deste 
estilo são infinitamente variadas. Observa Aymonino (2000), que em todos os países a arte de fabricar regularmente nasceu de um germe preexistente. Reafirma que sempre é necessário um antecedente; em nenhum modelo, nunca nada vem do nada; isto se aplica a todas as invenções dos homens.

Tanto a cultura vernacular quanto a clássica se baseiam na repetição de alguns tipos construtivos e espaciais fundamentais, que são a expressão universal das atividades humanas, do trabalho e do prazer, coletivos e individuais. Porém, sob o ponto de vista filosófico, clássico e vernacular não estão fundamentados em uma distinção de classes, mas na distinção entre coletivo e individual, entre monumentos e edificações urbanas, entre edifícios públicos e habitações privadas.

"Não nos interessam os monumentos" (SAGGIO, 2006) afirmavam os arquitetos modernos, interpretando Frank Lloyd Wright, e tinham razão. De fato, a palavra monumento (do latim monere, ou seja "fazer lembrar", "avisar", "iluminar", "instruir" entre as duas Guerras, era usada para exprimir o poder do Estado, freqüentemente uma ditadura que pretendia exaltar a autoridade, 0 poder, a hierarquia.

Os arquitetos modernos, aqueles do CIAM, tinham problemas bem mais prementes a serem resolvidos: a casa para todos, a utilização de novos materiais e novas tecnologias construtivas, o urbanismo e os assentamentos.

Mas é na habitação que se realiza o estudo de caracteres específicos, tipologias e suas modalidades de agregação na cidade. O próprio Secchi, em La città del ventesimo siecolo, afirma que "em continuidade com o reformismo oitocentista a habitação e a política da habitação permanecem, por um longo 
período, no centro da reflexão de uma multiplicidade de estudiosos e de atores institucionais".

\section{Ruas, Praças, Traçados}

A necessidade de infra-estrutura varia no tempo e de acordo com as classes sociais e muitas vezes refere-se a valores, em parte necessários e em parte distorcidos (os tais consumos induzidos). Esse fato produziu na história recente e, provavelmente, produzirá no futuro na avaliação de Carlo Aymonino (2000), uma oscilação entre necessidades individuais e necessidades coletivas, nem sempre com a intenção de "promover" as individuais em benefícios coletivos. Quando essas necessidades alcançam um estágio de organização mais complexo e articulado, com uma conseqüente tendência de se tornarem definitivas, isto é, estáveis em relação a um determinado período de tempo, nasce a ulterior necessidade (e, portanto, diversa daquela inicial) de realizar uma estrutura apropriada capaz de confirmar e desenvolver, resolvendo aquelas necessidades por meio da própria presença arquitetônica. Só então poderemos falar de equipamentos urbanos como núcleo originário da moderna tipologia arquitetônica não residencial. Este tipo de arquitetura foi definido durante o século XVIII como arquitetura civil e é com esse conceito que Aymonino observa as mudanças que ocorreram e os novos papéis que se entende atribuir à arquitetura.

No seu livro O Significado das Cidades, Aymonino coloca, ainda, que a arquitetura civil contemporânea não é somente a "não religiosa" ou a "não militar"; as novas arquiteturas tendem a identificar-se com a cidade nova, constituída não somente por edifícios, mas por ruas, esgotos, tubulações hidráulicas, iluminação. Não só o centro histórico de uma cidade ou 
construções de caráter artístico, histórico ou cultural são fundamentais na memória pública; os elementos que compõem a cidade contemporânea tendem a construir e formar identidades difíceis ou precárias, que se contrapõem com o ambiente urbano formado por elementos absolutamente concretos. Cada espaço da cidade faz parte de diferentes narrativas históricas.

A infra-estrutura organiza principalmente o tempo quotidiano do habitar, como também o tempo dos ciclos produtivos. O conflito social gerado freqüentemente pelos projetos infra-estruturais revela uma distância entre os modos pelos quais cada pessoa usa e habita a cidade e o desejo coletivo por uma cidade melhor, com mais qualidade no ambiente urbano.

Infra-estruturas são aqueles elementos necessários para satisfazer as necessidades humanas em uma determinada sociedade; de acordo com Aymonino, são necessários dois adjetivos para definir o caráter de uma infraestrutura - público e privado - indicadores de uma referência jurídica em relação à propriedade e à gestão. Por coincidência, ele relaciona o primeiro com o conceito de coletivo e o segundo com o conceito de individual; coincidência superficial porque existe uma série de infra-estruturas privadas com caráter coletivo.

A relação entre infra-estrutura e cidade tem várias nuances; tanto pode ser pouco significativa, como muito significativa, acontecendo de diferentes maneiras ao longo do tempo. O lugar onde está o papel que desempenha e as influências que uma exerce sobre a outra mudou significativamente, seja no tempo, seja devido à expansão urbana.

Porém, nas relações entre infra-estrutura e construção do espaço quotidiano, como já foi visto no capítulo anterior, o conceito de intervalo sempre 
foi e ainda é a chave para eliminar a divisão rígida entre áreas com diferentes demarcações territoriais.

Além disso, para Jane Jacobs (2000), ruas e calçadas constituem os mais importantes lugares públicos de uma cidade e seus órgãos mais vitais. Porém, isoladas, as calçadas da cidade não significam nada além de uma abstração; têm significado somente em relação aos edifícios quando se situam ao longo deles ou de outras calçadas imediatamente próximas, e a outras construções existentes.

Ao analisar as relações entre os serviços urbanos e seus equipamentos, Aymonino (2000) também constata que, dentro de uma nova estrutura urbana parcial, mas resolvida, existem mutações interessantes; os percursos, organizando-se em ruas, tornam-se serviços públicos coletivos com mais funções presentes: para pedestres (calçadas), para automóveis (faixas), para infra-estrutura (esgotos e tubulações em geral), etc.

Porém, o aumento do tráfego motorizado, sua prioridade e organização sem critérios nas áreas de acesso às moradias desvalorizam a rua como espaço comunitário; à medida que aumenta a prosperidade, desaparecem as afinidades entre os moradores.

Ao empregar o termo "metavernacular", cria-se um neologismo que transcende o significado do termo vernacular, já que o prefixo meta exprime uma estrutura cujas ramificações, no caso, seriam as diferentes realidades de um lugar. Entende-se como lugar o espaço construído ou não da cidade contemporânea, caso das edificações vernaculares, áreas verdes, áreas de obsolescência industrial e os próprios vazios urbanos, espaços abertos ou 
fechados, individuais, coletivos e espaços intermediários que dividem o espaço privado da rua.

O vazio não é imediatamente visível nos espaços intersticiais, aqueles praticamente imperceptíveis, ocultos entre os edificados. Esses vazios, esses espaços em negativo podem se ampliar indefinidamente pela contaminação da obsolescência vizinha. Significa um crescimento contínuo do indiferenciado. Indicativos de baixa atividade imobiliária, estes espaços são reservados assim para uso futuro; quando inutilizados, só se tornam perceptíveis ao atingirem o ponto crítico, a amplitude de toda a área, inviabilizando sua re-inserção no mercado comercial.

Extremamente ligada à semântica do espaço "metavernacular" está a natureza do espaço aberto, das ruas, das calçadas, das praças, dos jardins, dos pátios, das galerias, dos pilotis, ou seja, espaços de interconexão que estabelecem com o edifício relações variáveis e complexas. Isto depende de como os edifícios se apóiam, elevam-se e se abrem no solo; é a soleira que separa e une o espaço interno do externo e relaciona a estrutura urbana à arquitetura.

Às vezes, a rua é vitrine, noutras, é palco, lugar de trabalho ou de convivência; tudo depende da rua que está sendo focada. Certamente não é a das vias expressas, não é o espaço de circulação, mas aquela enquanto lugar e suporte de sociabilidade.

É a rua que resgata a experiência da diversidade, possibilitando o encontro entre desconhecidos, a troca entre diferentes pessoas, a multiplicidade de usos em um espaço público regulado por normas da 
administração municipal. É o espaço que se opõe, em termos de estrutura, ao do domínio privado da casa e das relações familiares.

Mesmo um pequeno edifício demarca o espaço público e se relaciona com ele. Se ele se relaciona com uma rua, avenida, alameda, galeria, praça, largo, cada um desses artefatos urbanos pode sugerir articulações diferentes na forma, dimensão, função, densidade urbana, relações espaciais e modos de habitar.

$\mathrm{Na}$ reflexão sobre os elementos que compõem o espaço urbano, nas relações entre edifício e rua, entre espaço público e lote privado, entre o espaço dos automóveis e o de pedestres, entre os próprios espaços construídos - abertos e fechados, cheios e vazios - entre a rua e espaços abertos, perderam-se muitos dos aspectos que caracterizavam a cidade. Seja por motivos de segurança, seja por individualismo exacerbado, o espaço semiprivado desaparece deixando em seu lugar grades e muros psicologicamente intransponíveis. Interesses econômicos ou mesmo políticos impediram de se contrapor possíveis alternativas a este modelo de infra-estrutura.

Em uma análise sobre a cidade contemporânea, Pierluigi Nicolin (1987, p. 11) constata que a ausência de espaço público na cidade contemporânea é interligável à redução, na cultura técnica dos urbanistas, das convenções que se exprimem em determinadas formas e por uma linguagem específicé

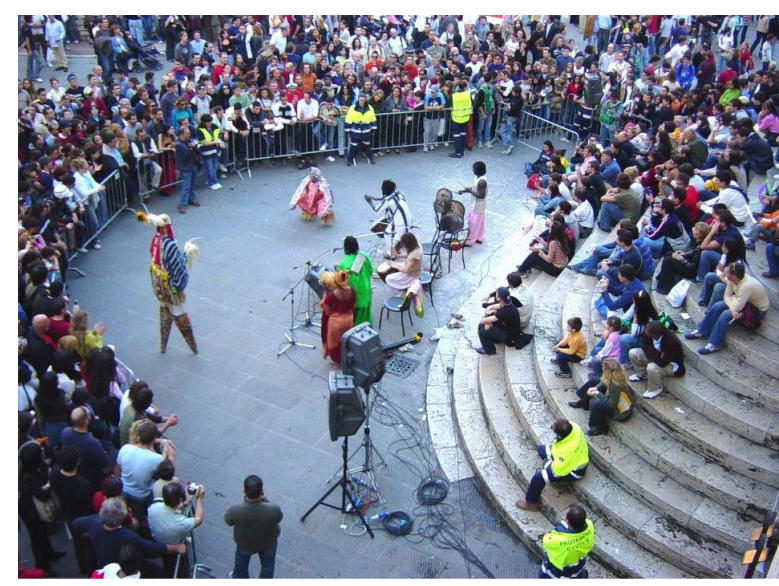

Fig. 21 - Concerto em uma praça em Peruqia, Itália socialmente aceita; os termos "rua", avenida", etc., têm conotações formais e 
espaciais bem precisas que compreendem milhares de ruas, avenidas e praças diferentes no tempo e no espaço. Na ausência dessas condições, tudo se confunde, o espaço da cidade se desagrega e a arquitetura, perdendo qualquer referência, cai na insignificância ou é conduzida a uma pura e simples redução do seu significado: o edifício se torna um sinal, uma imagem.

Jane Jacobs questiona, em diferentes momentos de seu livro Vida e Morte de Grandes Cidades, sobre as funções das calçadas e lugares públicos e o motivo pelo qual os lugares de reunião organizada não conseguem se desenvolver. Para ela, a grande questão é de que maneira a vida coletiva de tipo informal que se desenrola nas ruas pode ser apoio a uma vida pública mais formal e organizada.

O espaço público urbano significa um lugar privilegiado do exercício da cidadania e da expressão dos direitos civis; uma cidade que depende exclusivamente do automóvel e vive de edificações especializadas e fechadas não facilita o exercício da cidadania; uma cidade, onde automóveis e telecomunicações substituíram o contato humano, tende à segmentação, ao individualismo e à exclusão.

Diz Koolhaas em $S, M, L, X L$ (1994) que o espaço aberto da cidade não é mais um teatro coletivo onde "algo" acontece: não resta mais nenhum "algo" coletivo. A rua tornou-se um resíduo, uma engrenagem organizativa, um mero segmento do plano metropolitano contínuo no qual os vestígios do passado enfrentam as infra-estruturas do novo em uma inquieta situação de impasse. Mas a cidade não é feita só de grandes dimensões, observa ele, e não se pode fazer tábula rasa de uma cidade inteira, recomeçar das grandes dimensões e 
reinventar o coletivo. Ela coexiste com a cidade clássica mesmo sem estabelecer, conforme ressalta Koolhaas, relações diretas com ela.

Se a praça é lugar de encontro, descanso e ponto de observação, a rua convida ao movimento, estimula sensações mais ricas, desenvolve oportunidades de conhecimento de outras pessoas. É necessário apontar que as festas e a vida social que acontece nas ruas têm um caráter público e servem para reunir pessoas entre

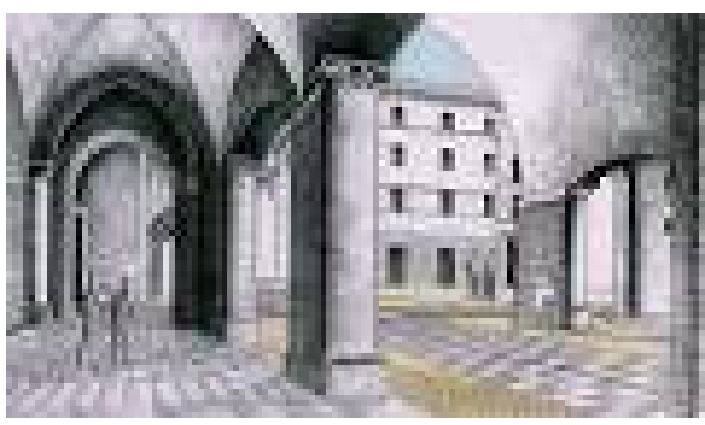

Fig. 22 - Pórticos em Imola, Itália as quais não existem conhecimentos íntimos ou particulares. Isto é, a dinâmica de interação entre as pessoas e os lugares públicos resulta em ações de pessoas que determinam a identidade de um espaço, ou seja, voltamos ao conceito de E. T. Hall (1966) sobre a proxêmica. O projeto de um espaço público pode propor visões que, mediante a reorganização das potencialidades e das energias, criam condições para estimular encontros e trocas.

Para Hertzberger (1996), o segredo é dar aos espaços públicos uma forma tal que a comunidade se sinta pessoalmente responsável por eles, fazendo com que cada membro da comunidade contribua à sua maneira para um ambiente com o qual possa se relacionar e se identificar. Em outras palavras, as partes da cidade, ricas em episódios, com suas variadas funções e momentos de atração, aumentam a sensação de "pertencer" nos cidadãos, que não terão mais necessidade de procura de novos modelos de espaço urbano.

Porém, ruas, praças e suas variantes são formas otimizadas para espaços coletivos. De fato, nenhuma empresa, pública ou privada, realiza 
espaços públicos espontaneamente, como livre expressão de suas atividades. O espaço público e seu domínio, sua qualidade estética e o seu poder de socialização nunca foram o resultado de um acontecimento casual, mas de uma percepção e de uma vontade civil.

O espaço privado torna-se cada vez mais restrito. Por outro lado, segundo Pierluigi Nicolin, (1987, p. 11) a privatização da cidade tem duas conseqüências contraditórias: por um lado, obriga o poder público a estender cada vez mais seu controle, por outro, impede a articulação do espaço com a criação de uma verdadeira arquitetura urbana. Porque a cidade, os lugares construídos, os espaços urbanos determinados pelas ruas e praças formam o grande e complexo universo de relações que permite a coexistência da "grande cidade pública" com as inúmeras "cidades privadas", as inúmeras situações de edificações produtivas, residenciais, serviços urbanos e comércio com as quais todo cidadão se relaciona a cada dia. A urbanização de um lugar se torna, hoje mais do que nunca, uma imagem importante da modernidade e do desenvolvimento.

A passagem da cidade moderna com lugares com referências centrais (equipamentos públicos como possíveis monumentos), ao sistema de percurso como modo de representação total das instalações urbanas, conforme nota Aymonino (2000) anula qualquer significado de homogeneização e globalização da cidade e de si própria, com as relativas percepções e imagens, dando às infra-estruturas o papel de elementos basilares da própria instalação. 


\section{O Genius Loci e o Não-Lugar}

É importante entender as relações entre arquitetura e o genius loci de uma cidade, como também o valor do monumento na cidade e suas relações com 0 ambiente, que se contrapõem ao conceito de monumento. $O$ monumento, além de sua existência ser historicamente determinada, possui uma realidade analisável. Construir monumentos pressupõe a existência de uma arquitetura, de um "estilo", e cada monumento possui uma individualidade. "São 'como datas'; sem elas, isto é, o antes e o depois, jamais poderemos entender a história." (ROSSI, 1978, p. 172).

Aquilo que era considerado monumento, elemento catalisador de paisagens, eventos, memórias, hoje significa a infra-estrutura para as periferias. Aquilo que era considerado monumento como lugar de agregação, hoje foi substituído pelo "percurso", ou seja, pelo lugar de passagem e, ao mesmo tempo, por novas formas de agregação. A ruptura, mais ou menos epistemológica no modo de viver, interpretar e transformar a periferia, deve necessariamente reconhecer esse processo. É nesse contexto que são situados os não-lugares contemporâneos.

Reitera Aymonino (2000), que as novas edificações possuem um novo papel ao se tornarem um ponto de referência dos percursos nos quais se organiza a nova estrutura urbana; assim, os limites entre "tipo" e "modelo" freqüentemente serão passageiros.

O século $X X$ é caracterizado pela formação de novos valores e referências, pela modificação contínua dos imaginários individuais e coletivos. Em relação ao espaço urbano, o século XX para Secchi (2000) é o da banalização, fragmentação e da progressiva burocratização. Ainda segundo 
ele, uma das principais características desse século é a autonomia do sujeito que emerge; cada vez fica mais evidente sua rejeição pelas instituições do poder e a resistência em desaparecer no anonimato de sua classe ou categoria; o individualismo mostra-se cada vez maior dando mais espaço aos aspectos privados da existência e aos valores de interesse puramente pessoal.

A atenção ao quotidiano caracteriza todo o século $X X$, evidentemente associada à crescente autonomia do indivíduo; depois de longo período de repressão ideológica, esse indivíduo atinge a abstração da cidade moderna, sua materialidade e suas diferenças. Cada indivíduo e grupos sociais inteiros conferem ao quotidiano uma importância tanto maior na medida em que se sentem menos representados pelas principais instituições políticas (SECCHI, 2005).

Os fatos que estão relacionados com a cidade e com o território são tão numerosos e nós estamos tão envolvidos que ainda é difícil fazer uma avaliação completa e convincente. O problema se agrava quando se impõe perguntar sobre o que se deve decidir, salvaguardar e desenvolver.

Podemos afirmar que nossos conceitos de função e fruição vão se diluindo numa continuidade de mutações de uso e significados e, por isso, a idéia de transformação e variação acaba coincidindo com a própria idéia de uso. O sentido da arquitetura está vinculado, cada vez mais intrinsecamente, à capacidade de compreender e solidificar o significado da mutação. 
Vimos que esta capacidade não está simplesmente ligada à definição tipológica, senão, mais genericamente, à forma do objeto arquitetônico. Não se pode obtê-la apenas mecanicamente por meio da transformação física do continente ou de sua indiferença funcional, mas também por um

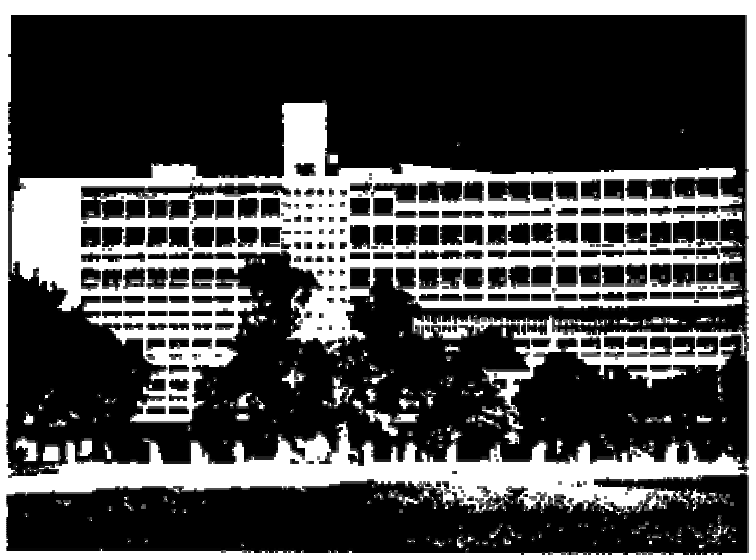
novo estudo de formas e de suas modificações, que institui por meio das qualidades do significado (qualidade densa em

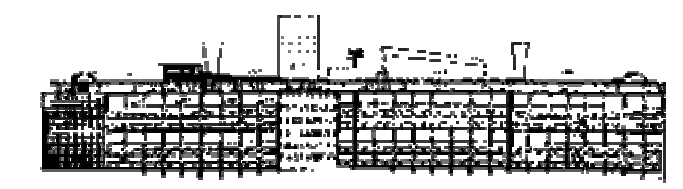
Fig. 23 - Unité d'Habitation de Marseille (Le Corbusier)

estratos e capaz de pôr em movimento contínuas e diversas decodificações), uma dialética com a multiplicidade de usos e uma rede de situações possíveis (GREGOTTI, 1977).

Invejamos as cidades européias sem perceber que no pequeno lapso de tempo determinado a partir de sua formação, e que demarca a história de nossas cidades, demolimos ao invés de tentar entender aquilo que é importante para preservar. Como ocorre com as pessoas, cuja formação depende de suas origens, antecedentes, educação e regras. Quando sua história não é lembrada, os indivíduos podem perder parte de si mesmos.

Nas cidades, cada construção, cada cheio ou vazio, faz parte de sua história. As relações que se estabeleceram e se conservaram no tempo entre o signo e seu significado, na forma da cidade e seu papel e as funções desenvolvidas por cada elemento que constitui o espaço urbano, fazem parte de sua história. 
O problema de diferenças sociais mais complexas da cidade, além daquelas históricas, pode acentuar a forma das diversas soluções arquitetônicas de caráter urbano. Forma que adquire caráter de necessidade enquanto oferece às próprias diferenças sociais a possibilidade de serem representadas, de existirem com uma linguagem arquitetônica própria (2000).

Qual o sentido em arquitetura, tanto em termos gerais quanto específicos, do termo coletivo, escreve Aymonino quando as instituições e seus correspondentes equipamentos arquitetônicos, ditos coletivos, hoje são compreendidos, construídos e, principalmente, usados como lugares nos quais, casualmente ou não, se somam apenas exigências individuais de maior número de pessoas. É importante lembrar a ilusão da sociologia norteamericana produzida pelos shopping centers como lugares sociais; a rápida difusão do esporte passivo, a crise das instituições como o cinema ou o teatro, etc. E o fato de as cidades antigas cada vez mais adquirirem papel comparável ao dos fenômenos naturais em relação ao turismo de massa.

Hoje, também assistimos à difusão virtualmente infinita dos não-lugares. Eles vivem não só como os da cidade consolidada, de sua presença física e identidade, mas também do efêmero tempo da percepção, do uso e consumo mais ou menos ocasional por um indivíduo anônimo. São lugares não habituais, não permanentes, mas, como quaisquer outros objetos de consumo, submetidos à lógica da moda, destinados a seguir as mudanças periódicas e improdutivas das tendências coletivas. 


\section{Extensão do Conceito de Preservação}

Quando se começou a considerar históricos não só os feitos dos grandes, mas também as do povo, o valor de historicidade da cidade estendeu-se a todo o tecido urbano. (ARGAN, 1993, p. 260).

A eternidade é o significado intrínseco da memória, alimentando nas ciências humanas uma idéia de progresso que - radicado no passado permite manter vivas e operantes as relações entre seus próprios valores. "Escrever para a eternidade" (RUSSO, 1998, p. 75) é uma metáfora, mas não há dúvida que a obra de arte não é superada do mesmo modo em que são superados objetos tecnológicos. Este ponto de vista esboça como o saber científico age no passado por meio de seleção e eliminação, enquanto as ciências humanas estão mais ligadas à seleção para a sua recuperação.

O trabalho seletivo, afirma Michelangelo Russo em seu livro Aree dismesse, adquire um valor progressivo no patrimônio da memória e do passado e informa uma posição teórica cuja conservação é guiada pela intenção de "atenuar o esquecimento", de afirmar uma memória coletiva como conjunto de valores ligados a uma tradição, instituições e idéias.

Conservar quer dizer, em primeira instância, individuar os valores implícitos nos bens culturais e nas relações existentes entre o patrimônio e a cidade; significa também individualizar estratégias para sua manutenção e sua continuidade em relação aos significados que os traçados do passado 
assumem em relação às novas exigências e às novas formas da vida associada.

\begin{abstract}
A ampliação do conceito de conservação está relacionada com a passagem de uma cultura integrada, cuja permanência dos valores na história está conectada à idéia de projeto. $\mathrm{O}$ ambiente urbano, o território, são, portanto, referências para criar ou modificar as relações entre os bens que são objeto de conservação e cuja importância vai além do aspecto físico e estético (RUSSO, 1998, p. 76).
\end{abstract}

Mas, em muitos casos, a preservação torna-se operação contraditória. A política de preservação, de fato, é dominada por uma intenção documental e pedagógica, muitas vezes não totalmente clara, que constrói escalas de valores, contradizendo freqüentemente a mesma história que se pretende testemunhar. O tema é bem conhecido: em vez de estudar o processo de alteração dos edifícios e dos espaços urbanos, o processo de seleção cumulativa responsável pelo extraordinário palimpsesto de toda cidade antiga procura se fixar, arbitrariamente, em um estatuto imutável. Ao invés de se estudar a história, o papel das técnicas construtivas e da articulação dos edifícios e dos espaços urbanos, modifica-se o comportamento estrutural de edifícios e de partes inteiras da complexidade urbana, com a inserção de materiais, técnicas e concepções estruturais a eles danosos; em vez de estudar as relações entre espaços, atividades e práticas dos centros antigos, impõem-se ao centro antigo e à cidade moderna papéis e funções que os submetem a um excesso de pressão ou de abandono. (SECCHI, 2000).

É importante que se estenda o conceito de conservação de monumentos arquitetônicos para a fisionomia da cidade como um todo, por meio de "revitalizações" ou mesmo "restauros", para melhor se compreender as 
intervenções urbanas. O tecido histórico - como trama do existente - deve ser considerado dentro do seu contexto, ou seja, como um sistema contínuo de referências para a transformação e tutela dos valores históricos e culturais. $O$ ambiente urbano e o território são, portanto, referências para criar ou modificar as relações entre os bens que constituem objetos de conservação e têm uma importância histórica que vai além dos aspectos arquitetônicos físicos e estéticos.

$\mathrm{Na}$ Europa, e de modo particular na Itália, um novo conceito de "herança histórica" amplia a opinião tradicional de relação monumento/documento, ou seja, o conceito de patrimônio não se limita aos monumentos, mas se estende progressivamente à herança do passado, da mais distante à mais próxima, por características de ordem cultural. A prioridade, dirigida somente à conservação de obras relevantes, começa a abranger edificações sem importância arquitetônica significativa, prevalecendo o valor da história sobre a estética. Hoje, após décadas de reflexão, alguns historiadores ainda insistem em diferenciar a arquitetura, como menor, maior ou monumental.

A idéia seria ampliar a preservação aos tecidos urbanos menores, áreas e imóveis industriais obsoletos ou abandonados, arquitetura rural e vernacular, formas de paisagem alterada pelo homem. "Desta maneira, a questão do patrimônio se tornaria o resultado de um processo complexo de seleção crítica agregada a um valor memorial" (RUSSO, 1998, p. 12).

Todo discurso de preservação da memória, da história e da identidade é questionado pela forma, tipo e modo de apropriação desses espaços. A reutilização de um bem é a maneira mais eficaz para garantir sua preservação, pois um monumento sem uso se deteriora rapidamente. Os poderes econômico 
e comercial se apropriam do valor cultural; para ser usufruído pela cultura predominante, acabam por desvinculá-lo de toda a sua rede de relações anteriores.

Uma dinâmica que engendra permanente proliferação entrópica, o acúmulo de construções abandonadas, fábricas vazias e áreas de demolição convertidas em estacionamentos, centros de culto ou depósitos, são espaços à espera de valorização. É o momento de conciliar a re-interpretação da multiplicidade e densidade da cidade histórica com as exigências do presente, ocupando o "vazio" com edifícios e espaços bem definidos.

Sem nunca ter realmente deixado de existir, persiste o desejo mercadológico e financeiro, em substituição ao aspecto quase metafísico que a cidade tinha no passado. Com uma preocupação de agregação de valor econômico ao patrimônio, a escolha de um tipo de uso não compatível com o edifício, imposta por interesses puramente econômicos e sem uma atenta avaliação do impacto que pode produzir no próprio edifício e seu entorno, seja ele um monumento, uma indústria obsoleta ou uma arquitetura vernacular, pode resultar em danos comparáveis àqueles determinados por um abandono.

Observa o sociólogo francês Henri-Pierre Jeudy que a revitalização dos centros históricos provoca a sua morte, transformando-os em "museus". Segundo ele, esta transformação tem como origem uma estratégia de marketing para atrair turistas e que se soma ao temor da população de perder sua identidade cultural. Contraditoriamente, diz ele, o resultado são cidades mais homogêneas e menos interessantes. O sociólogo acredita também que essa preservação está ligada ao medo de se perder a identidade cultural; uma contradição, no seu entender, porque acredita que a cidade sempre possui 
identidade, mesmo que não seja bonita. Cita como exemplo São Paulo, cidade "considerada muito feia, mas cuja feiúra é de uma estética fantástica; pode-se amar também o que há de feio na cidade, a ponto de esses territórios passarem a ser considerados tão bonitos quanto o centro de Salvador", observa Jeudy (2005).

A beleza de uma cidade, porém, não depende de seu aspecto morfológico. O mais apropriado seria enfocar o genius loci, ou seja, o espírito do lugar, aquela matéria abstrata cujo espaço físico pode criar, segundo Heiddeger, uma relação existencial entre o homem e o ambiente (NORBERGSCHULZ, 1979), que sobrevive às contínuas modificações das estruturas urbanas e confere um caráter indestrutível à cidade e à paisagem. Já diziam os povos antigos que um lugar com genius loci era um lugar ligado ao cosmo.

Para alguns autores, como Augé, a metrópole vive e cresce ignorando e destruindo a natureza peculiar dos lugares, apagando diferenças e complexidades, cobrindo o território de funções e de não-lugares, ou seja, de espaços sem identidade, relações e história.

A verdadeira vitória do mercado e de suas mais aberrantes formas especulativas sobre o projeto civil hoje, afirma Secchi, é totalmente representado, tanto em termos práticos quanto teóricos,

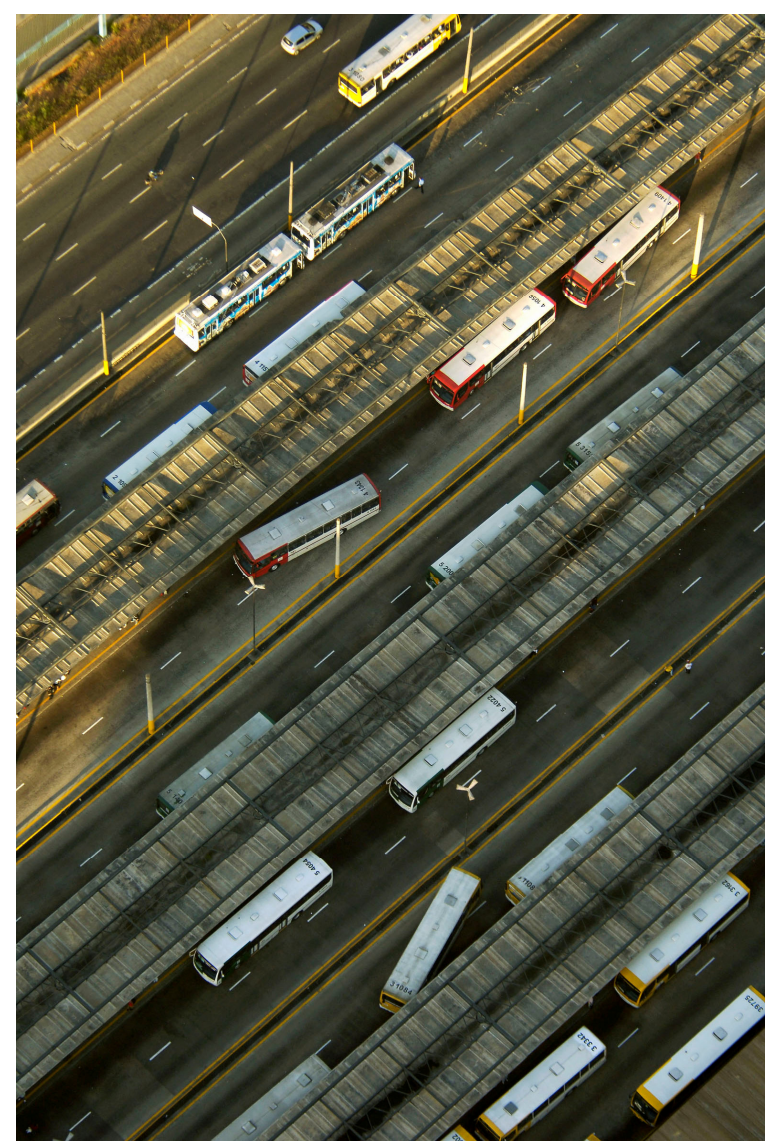

Fig. 24 - Terminal de onibus Dom Pedro II - SP 
no urbanismo quantitativo, na tentativa de reduzir de maneira homogênea os valores que governam as construções e transformações da cidade, segundo valores financeiros (SECCHI, 2000).

A cidade antiga é uma estratificação de traçados e de memórias, cujas relações de proximidade e vizinhança são o resultado de cada época que representou no próprio projeto de cidade sua idéia de espaço; traçados e memória que agiram no imaginário e no comportamento coletivo, seja na cidade medieval, renascentista, colonial ou mesmo industrial. Ignorar a importância dessas imagens e os processos pelos quais elas se tornaram imagens em que sociedades inteiras se reconheceram, pode ser um erro; muitos projetos contemporâneos procuram recuperar na cidade uma certa compostura, sem com isso levá-la a assemelhar-se à cidade do passado.

O centro antigo, porém, não deve ser pensado como museu, como realidade a ser considerada externa de um ciclo vital de transformação; ao contrário, deve existir uma relação entre o que se constrói e o que se recupera na cidade.

Assim sendo, escreve o urbanista napolitano Michelangelo Russo (1998, p. 76):

\begin{abstract}
a extensão do conceito de conservação está relacionada com a abertura de uma cultura setorial (essencialmente ligada ao valor histórico, de um patrimônio arquitetônico visto essencialmente como monumento) direcionando-se para uma cultura integrada, na qual a sobrevivência dos valores da história conecta-se à idéia de projeto. $\mathrm{O}$ ambiente urbano e o território são referências para se criar ou modificar as relações entre os bens que são objetos de conservação, cuja importância vai além da dimensão física e estética.
\end{abstract}

$\mathrm{Na}$ declaração final do Congresso sobre o Patrimônio Arquitetônico Europeu de Amsterdã, em 1975, foi afirmada a validade dos princípios de 
"proteção global" e "conservação integrada", subentendendo-se "integrar os valores da conservação do patrimônio cultural com as formas complexas da cidade, entendida como conjunto de funções, relações e práticas sociais" (RUSSO, 1998, p. 76). Tal complexidade requer uma visão intersetorial e interdisciplinar dos problemas urbanos, com condições de equilibrar as ações de conservação e modificação, mas também de assegurar a continuidade e desfrutar os valores da história. Ambos os princípios - proteção global e conservação integrada - afirma Michelangelo Russo (1998, p. 76), "fundam seu reconhecimento na validade dos dois elementos essenciais para a vida associada: o significado do patrimônio arquitetônico e a legitimação de sua conservação".

A sensação de pertencer a um lugar por parte dos indivíduos que o habitam, nasce e é alimentada com elementos da história pessoal ou familiar, relacionados com os próprios lugares; lugares se tornam códigos de memórias coletivas nos quais os cidadãos se reconhecem. Com isso se quer dizer que a memória não é simples lembrança do passado, mas subjetividade do presente, fonte de identidade; historicamente, materializa-se e é representada de maneiras diversas. Exprime-se por meio de formas artísticas, pintura, escultura, arquitetura e literatura. Pode ser organizada em arquivos, imagens, audiovisuais e enriquecida por sujeitos coletivos como família e associações ou instituições como escolas e organizações estatais.

A sociedade habita a cidade e nela organiza seus espaços e ambientes, elabora suas relações, celebra e demole legendas, mitos, ideais e ideologias, manifesta suas inerentes ou novas diversidades. Portanto, história social e 
história urbana avançam para uma interação complexa, onde guerra e paz deixam sinais e signos dos tempos, sedimentando riquezas e tragédias.

A preservação, nesta sua concepção mais recente, constitui o modo sempre mais decisivo, uma base de fundo para práticas artísticas, projetuais e criativas em geral; isto é, para aqueles que usam como instrumento de conhecimento a imaginação e a memória. A conservação se torna assim um percurso privilegiado em direção à lembrança do passado, como seleção crítica daquilo que tem valor coletivo: uma postura preservadora se afirma no contemporâneo em contraposição a uma idéia de modernização "que tudo destrói e esquece" (RUSSO, 1998, p. 75). As noções de memória e esquecimento constituem aquela membrana semipermeável que, na interpretação de Paolo Rossi (citado em RUSSO, 1998), distingue as ciências naturais das ciências humanas: a dialética entre eternidade e transitoriedade indica o modo diferente de conceber o passado como material sobre o qual construir o futuro.

A transitoriedade é o valor que prende a ciência ao seu progresso; o esquecimento, como estatuto do transitório, leva o saber precedente à superação das teorias, coincidindo com o avançar dos percursos da pesquisa científica.

Para Jeudy (2005), na Europa, no entanto, persiste o dever de cultivar a memória. A conservação patrimonial visa proteger os rituais, manter uma lembrança simbólica do espaço. "Na Europa, as pessoas sentem culpa quando esquecem algum fato histórico, o que também resulta das guerras, pelas quais passaram" (JEUDY, 2005). 
A forma da urbs é a realidade na qual a civitas se reconhece e se identifica e é composta pela consistência de seus tecidos, pela representatividade de seus edifícios coletivos, pela permanência de sua história; assim, a representação da identidade coletiva torna-se um estratagema para caracterizar e re-qualificar o espaço urbano. É bom lembrar que na língua latina urbs significava o espaço físico e civitas o social (RUSSO, 1998).

A identidade da metrópole atualmente é aquela de figuras parciais, de fragmentos emblemáticos e de uma perda de valores básicos de urbanidade e de vida coletiva; por essa razão, o centro histórico deve estar cada vez mais integrado às exigências da cidade contemporânea, estabelecendo porém relações significativas nas suas diferenças com os conceitos de cidade e memória.

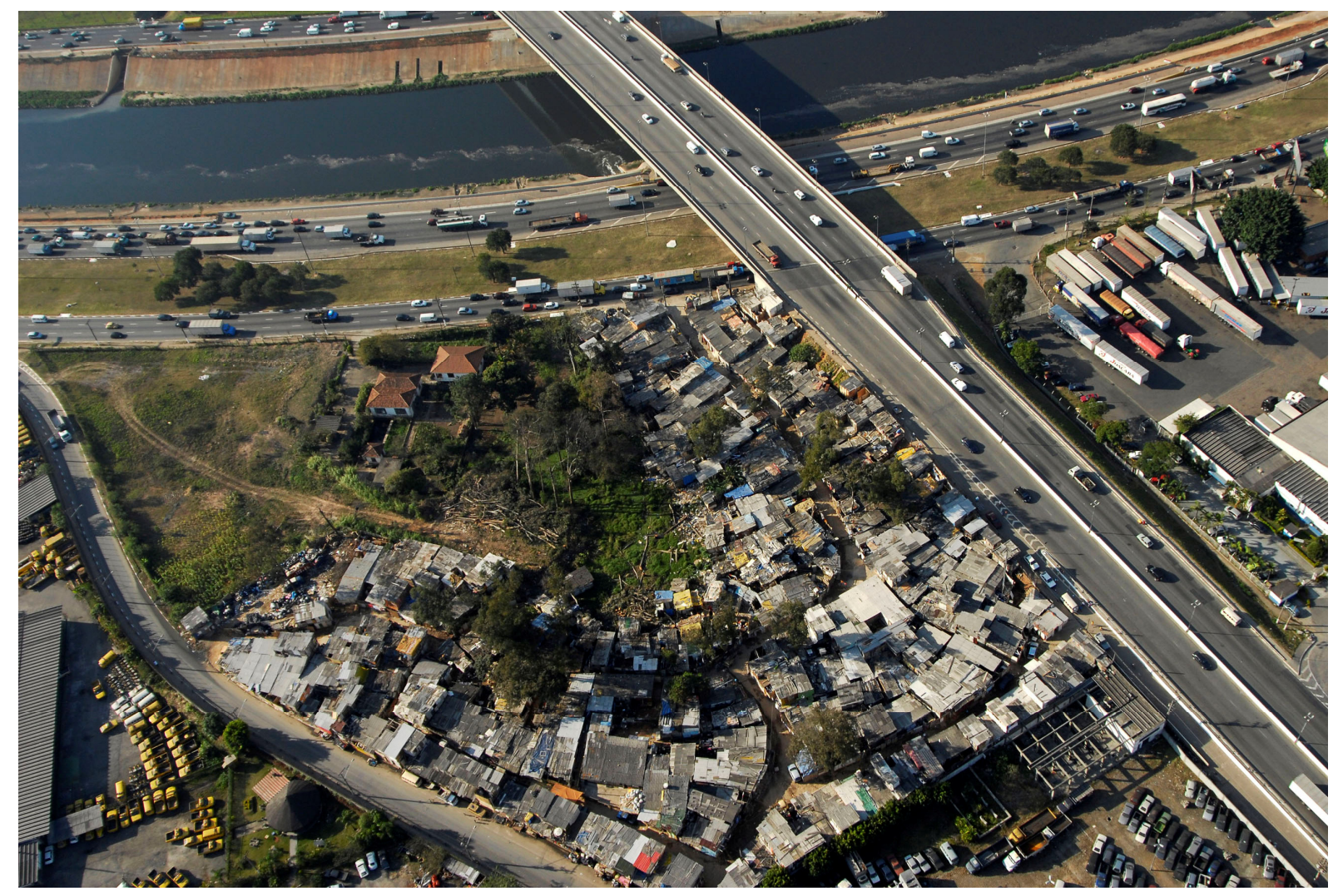

Figura 25 - Favela Marginal Tietê / Ponte de J. Mesquita Neto - SP 
A evolução do conceito de conservação constitui o resultado de um processo teórico obtido através da idéia de conjunto urbano, de paisagem e ambiente, compreendidos como finalidades gerais para orientar qualquer tipo de política. Isto ocorre segundo Russo, a partir de uma noção de bem cultural e de memória ligados essencialmente a um edifício, a um monumento ou a uma criação artística, cuja dimensão e importância histórica podem ser mais ou menos expressivas.

$\mathrm{Na}$ Europa, a partir do século XV, muita gente começou a reler os clássicos gregos e latinos, a visitar e dar importância às arquiteturas daquele período, a procurar imitá-las na tentativa de reconstruir, em oposição à "maneira gótica", um mundo tal qual se imaginava que fosse o da Antiguidade Clássica. Mas o que se produziu foi algo muito diferente e novo, uma esplêndida re-elaboração do passado à qual damos o nome de Renascimento, e que consideramos o início da modernidade (SECCHI, 2000).

A operação de demolição, como a própria história ensina, é parte integrante do processo de construção e regeneração da cidade, provocado em geral por mudança de cânones estéticos, funcionais, militares ou sociais que induzem julgar anacrônica e obsoleta a produção arquitetônica vernacular de um determinado período.

A defesa do antigo e a intensificação da produção arquitetônica e artística contemporânea são dois lados de uma mesma moeda: são ações paralelas que devem coexistir e sobrepor-se com a firme intenção de melhorar a qualidade do espaço urbano.

Conforme Michelangelo Russo, o passado não é uma realidade a ser fossilizada ou re-proposta; ao contrário, o passado deve ser decomposto e 
analisado por regras e referências estruturais precisas. E, como já notavam Karl Marx no 18 do Brumário de Louis Bonaparte, e mesmo os conceitos de base de Sigmund Freud, sem um profundo conhecimento e análise do passado não há perspectivas para se corrigir o presente.

Em História da Arte como História da Cidade, Argan (1993) já afirmava que

\begin{abstract}
a lembrança do passado é instrumento de conhecimento que vai além da memória. Se a conservação pode inibir a criação, a falta de zelo para com o patrimônio histórico pode levar à perda dos fundamentos históricos do conhecimento, indispensáveis a toda criação contemporânea e mesmo à inovação.
\end{abstract}

Técnicas de expansão foram substituídas por práticas de recuperação e remodelação fundamentadas na história, por meio de significados coletivos, intrínsecos e estratificados, ou seja, baseados nas tradições regionais e pertencentes à cultura popular. Esta se manifesta de modo muito diferente em cada região em função de suas raízes, costumes e identidade. A recuperação deveria considerar os efeitos do re-equilíbrio e da transformação em escala urbana e territorial, levando em conta a ampla estratégia de valores.

Em resumo, pode-se dizer que a construção da cidade se desenvolve em um processo contínuo de modificações, demolições ou reconstruções que acompanham ou contrastam com as transformações sociais da história.

\title{
A Obsolescência Industrial
}

A obsolescência e a desativação industrial também pertencem à história da cidade, seja como fenômeno contínuo de substituição, seja como abandono 
repentino que inesperadamente muda a geografia urbana. Grande parte da cidade medieval foi construída sobre lugares entre edifícios e dentro de espaços obsoletos e desativados da antiga cidade clássica, recuperando os materiais, contaminando-os com novas práticas sociais. A obsolescência e a desativação não implicam apenas uma mudança da distribuição das atividades dentro do espaço urbano. Indicadoras de uma impossibilidade, a obsolescência e desativação freqüentemente implicam mudança de escalas e de relações espaciais (BENEVOLO, 1993; SECCHI, 2000). O objeto de reestruturação e expansão, no Brasil, não é a cidade medieval, mas sim a cidade colonial.

As habitações construídas a partir de 1950 em diante, também sofrem um ritmo acelerado de obsolescência. Entretanto, a intervenção em edifícios contemporâneos exige maior atenção crítica e a discussão sobre preservação em certas mega-estruturas de habitaçao popular com perfil degradante, deve ser bem avaliada.

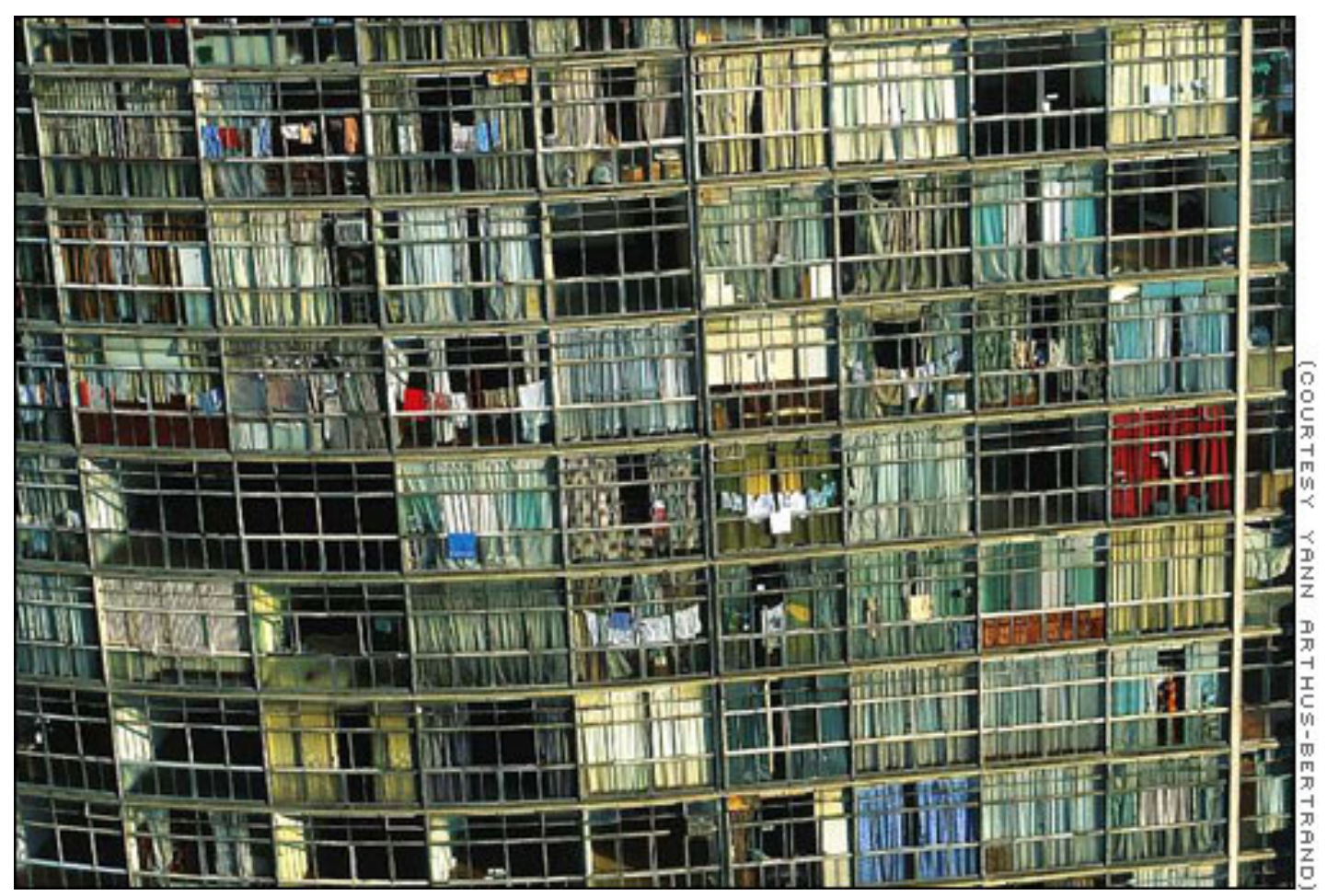

Figura 26 - Edifício São Vito - SP 
O fenômeno da obsolescência industrial e da descentralização desse setor ocorre pelo menos há 30 anos na Europa. É possível, assim, traçar um roteiro das mudanças através do reconhecimento das diferenças de cada caso, de suas origens, condições e valores estratégicos. Muitas dessas áreas já desocupadas ou em fase de abandono são extensas, outras menos expressivas, podendo mesmo se tratar de edifícios isolados, mas o contexto urbano e as carências subjacentes serão fundamentais.

Uma reflexão sobre o princípio da conservação, que leva a considerar sua "proveniência" e sua progressiva extinção durante a história, feita por Michelangelo Russo, pode levar à afirmação de que a cidade industrial e seus múltiplos significados, sub espécie de extintas áreas industriais, constituam parte integrante do patrimônio urbano.

É indispensável definir a condição pós-industrial da cidade a partir de fenômenos de declínio urbano, da crise dos modelos e das lógicas de produção conseqüentes das crises energéticas, revolução da informática, até transformações de mercados e assim por diante. (RUSSO, 1998)

Vez ou outra, em razão das novas técnicas de comunicação, a atividade desterritorializa-se, dissolve-se como uma nuvem, dispersando-se em uma miríade de lugares e de terminais que utilizam infra-estruturas em grande parte imateriais; em outras ocasiões, a atividade desloca-se para diversas partes do mundo, deixando para trás uma classe operária velha e desmotivada, da qual apenas uma parte consegue inserir-se em outros setores produtivos. Em algumas circunstâncias, no entanto, a atividade apenas se transfere para outros edifícios localizados na mesma cidade, modificando a geografia 
funcional ou simbólica e, sobretudo, transformando-a na "cidade difusa" (SECCHI, 2000).

Essa descentralização industrial não está ligada somente à transferência das áreas de produção, mas à modernização de serviços e infra-estruturas. Ela cria a perspectiva de uma melhora do equilíbrio demográfico e do preenchimento das carências de serviços em determinadas áreas da cidade, prevalecendo o conceito de construir no já construído.

Mas nem tudo que caracterizou a cidade industrial - fábricas, áreas de produção, equipamentos superados - pode ser considerado como patrimônio, como objeto a ser conservado e tutelado. Isso exige uma revisão analítica e crítica desses valores, isto é, quais valores manter, como mantê-los e que relações devem estabelecer com a cidade.

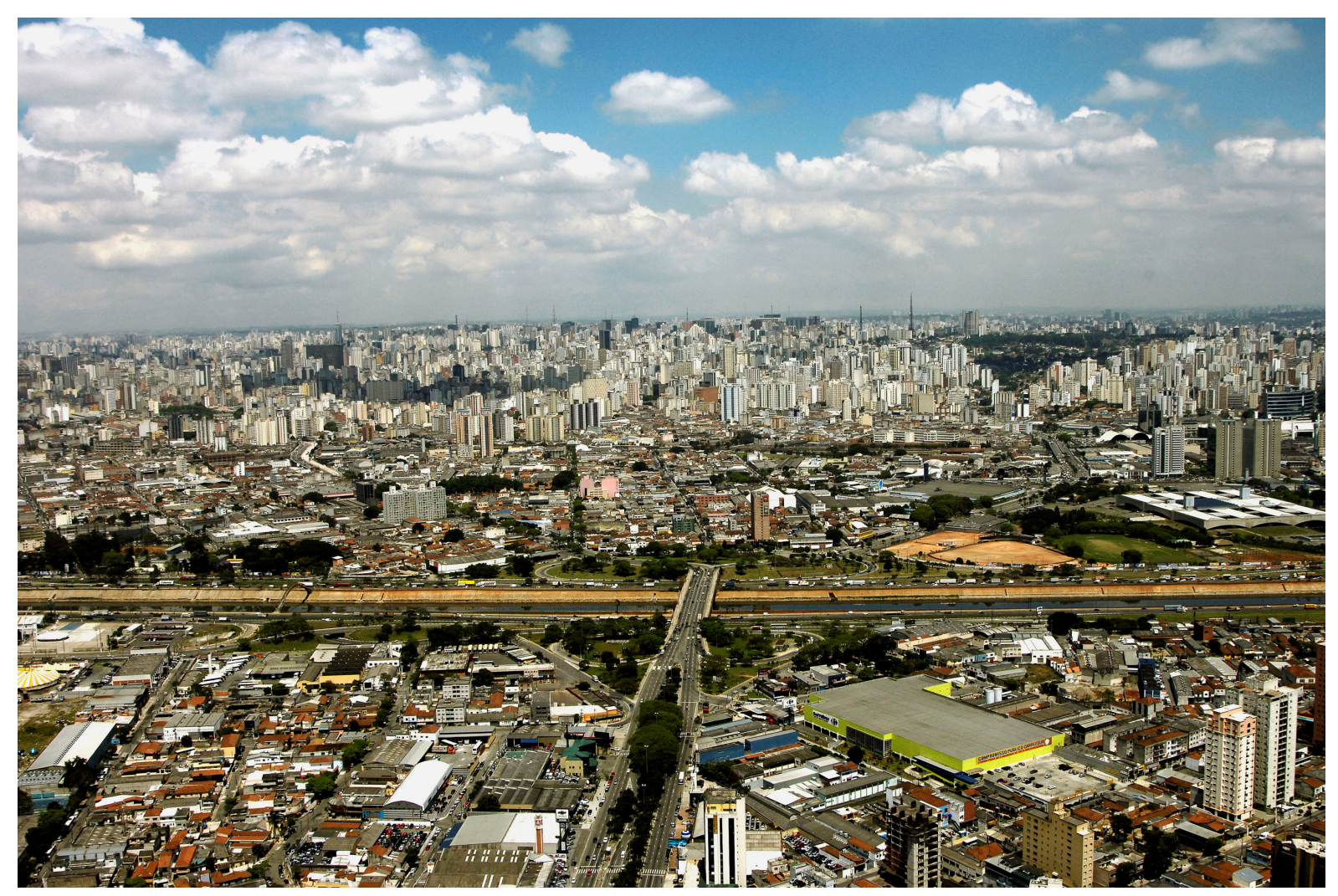

Figura 27 - Marginal Tietê / Ponte do Pacaembú - SP 
Essas fábricas, armazéns e galpões, antes em regiões relativamente afastadas dos centros das cidades, hoje, engolfados pelo crescimento urbano, ganham nova centralidade. A obsolescência industrial gera estratagemas, pois torna disponíveis para novos "tipos" de usos, áreas e partes do território ou imóveis com uma posição central e estratégica no contexto urbano, e um grau de infra-estruturas e relações de diferentes intensidades, mas já existentes.

A reutilização destas áreas e edifícios é geralmente caracterizada por novos usos e funções de caráter coletivo e público, com tendência ao saneamento ambiental. E, com a mesma lógica de marketing para conservação de monumentos, os investimentos privados têm grande interesse neste tipo intervenção.

\section{Do Restauro Romântico ao Restauro Crítico}

É importante reconstruir um percurso que, a partir do fim do século XIX, mostre como o conceito de preservação se transformou. Se antes a preservação era uma finalidade ligada ao significado de monumento e de patrimônio histórico-artístico e à tutela de seus valores simbólicos, por meio de técnicas e práticas específicas, hoje, a ampliação da disciplina do restauro faz com que a conservação assuma progressivamente a dimensão de "método" em relação a regras e abordagens que integram diversos saberes e diferentes disciplinas.

É no Renascimento que se inicia o interesse por edificações do passado, principalmente aquelas da Antiguidade Clássica. Alberti teve papel de grande relevância com seu tratado De re aedificatoria, escrito em 1452, 
baseado no estudo de autores latinos e gregos, em particular dos dez livros $D e$ architectura, de Vitruvius. Mas, a noção de historicidade como entendida hoje, começou a se estruturar somente a partir do século XVIII, com o nascimento da arqueologia e da antropologia, ciências incentivadas pela descoberta, em 1740, das cidades romanas de Herculano e Pompéia. Com o lluminismo despontava um sentimento de proteção em relação a um passado arquitetônico, a edifícios notáveis e a ambientes urbanos ameaçados de perda irremediável devido às incessantes transformações. Entretanto, os pesquisadores estavam mais interessados nos vestígios de civilizações antigas, egípcias, gregas e romanas.

A primeira metade do século $\mathrm{XIX}$ até as primeiras décadas do século $\mathrm{XX}$ constituem um período dominado por um pensamento elaborado por dois teóricos com tendências opostas, em relação ao restauro, o arquiteto francês Eugéne Viollet-Le-Duc (1814-1879) e o pensador e escritor inglês John Ruskin (1819-1900). Suas teorias foram consagradas pela historiografia da preservação de monumentos históricos, pela grande influência que exerceram em sua época e resultaram em atuações e posturas de capital importância.

Viollet-Le-Duc formula o restauro estilístico, em que o restaurador deve penetrar na mentalidade do arquiteto que realizou a obra a ser restaurada. Ele desenvolve extensamente suas idéias em 1858, reproduzidas no seu Dictionnaire raisonné d'architecture, no qual acreditava que restaurar um edifício não queria dizer apenas conservar, reparar ou reconstruir, mas aperfeiçoá-lo a uma condição de plenitude como ele jamais esteve. A partir destes princípios, numerosas obras foram restauradas com uma metodologia arbitrária e manipulados sem muitos escrúpulos, pois complementações e substituições destruíram características específicas do objeto em questão. 
John Ruskin, por sua vez, testemunha o desenvolvimento da Inglaterra e as transformações ocorridas na Europa com a Revolução Industrial; ele acreditava no artesanato como expressão da criatividade humana, da sua individualidade e de seu equilíbrio com a natureza e com Deus e se opunha à produção industrial enquanto causa de alienação e despersonalização. Através dessa ótica, Ruskin afirmava que o monumento devia permanecer assim como estava, conservado apenas, sem intervenções, modificação ou falsificação. Segundo ele, o monumento quando está em ruínas deixa de ter uma imagem de acabado e adquire uma dimensão infinita que se confunde com a natureza, este tipo de intervenção foi mais tarde denominado restauro romântico. Para Ruskin, mesmo a simples substituição das antigas pedras destruiria 0 monumento e como resultado se obteria somente um modelo do velho edifício.

John Ruskin e o artista inglês William Morris (1834-1896), um dos principais fundadores do movimento britânico Arts and Crafts, mais tarde prefiguram um sentido de conservação como distinção entre o espaço do conhecimento e da interpretação e o espaço criativo. Pensam a conservação da cidade como estrutura carregada de relações com o antigo, cujo tecido deveria ser considerado patrimônio intocável, e cuja salvaguarda assumiria caráter de uma prática que bloqueia os efeitos devastadores do tempo.

Depois de quase meio século de predomínio do método estilístico na Itália, durante as décadas de 1880/1890, amadurecem novas posturas em relação às posições extremas de Viollet-le-Duc e Ruskin - o restauro histórico e o restauro moderno - associadas respectivamente às figuras dos arquitetos Luca Beltrami (1854-1933) e Camillo Boito (1836-1914). 
O restauro histórico se fundamenta na filologia e na convicção de que todos os monumentos são distintos e finalizados por si mesmos; o monumento é considerado essencialmente como um documento. As intervenções deveriam ser realizadas baseando-se em dados de arquivos, livros, gravuras e na análise da própria construção, portanto, em provas fornecidas pela pesquisa histórica e pelo próprio objeto de estudos.

Em relação ao restauro moderno, Boito já em 1883 concebia os monumentos como documentos da história da civilização, apoiando radicais demolições na Itália sem sensibilidade ao contexto ambiental. Ele acreditava, basicamente, que os monumentos são documentos da história dos povos; neles deviam ser evitados acréscimos e renovações, embora as alterações ocorridas em outras épocas pudessem ser consideradas como partes dos mesmos.

O arquiteto e historiador vienense Camillo Sitte (1843-1903), sugere que o espaço urbano torne-se o espaço em negativo da arquitetura. Considera o espaço entre edifícios com vida própria, como se se tratasse de um monumento. Em seu livro L'arte di costruire le città (A Arte de Construir as Cidades, 1981), até hoje uma referência para os arquitetos, ele observa que a cidade antiga constituía uma figura histórica, um modelo evolutivo cujo último estágio coincide com a civilização industrial. Posiciona-se contra a rigidez e simetria dos projetos urbanísticos contemporâneos, criticando o isolamento dos monumentos, preocupando-se com a estética das cidades. Defende a preservação e perpetuação dos tecidos urbanos tradicionais, onde as pessoas se sentiam bem. Ele afirma que a decadência da qualidade estética da cidade moderna ocorre devido à falta total de princípios de composição que controlem 
a escala dos projetos e as técnicas de construção. Com referência à forma da cidade antiga e seu estudo morfológico, seu método de refletir sobre a história e sobre a conservação, torna-se instrumento de conhecimento do projeto para se obter aspectos formativos e estruturais.

A obra de Alois Riegel (1858-1905), arquiteto e historiador de arte austríaco, reformula as bases teóricas para a definição do conceito de monumento. Seu raciocínio para um conceito moderno de patrimônio urbano fundamenta-se em uma codificação de valores que estão além do caráter puramente estético e semântico. Para ele, o valor do antigo é totalmente independente dos valores que se encontram no material, na tradição das técnicas de execução e no significado histórico-artístico. Na realidade, o valor manifesta-se pela deterioração lenta, que não cessa nunca. $O$ valor da antiguidade representa a memória, isto é, reaparece nos sinais do tempo que permanecem.

Entretanto, antes de continuar este breve, mas indispensável excursus histórico, é fundamental registrar o pensamento do filósofo alemão Nietzsche que, de certo modo, influenciou a intelectualidade da época. Nietzsche (18441900) exaltava a necessidade da história para a vida e a ação. Voltando-se contra a "história decorativa", escreve: "Queremos servir à história somente na medida em que ela sirva à vida".

A cultura moderna, para ele, parece tomada por uma "hipertrofia" do saber histórico - a doença histórica. Para descrever e tentar curar esta doença nociva, Nietzsche escreve "Sobre a Utilidade e Danos da História para a Vida". O esquecimento, segundo ele, é necessário para a vida; para se poder viver no presente, é necessário esquecer o passado, para que ele não nos domine, nem 
paralise. Esse pensamento não significa que a história, fundada na memória do passado, seja inevitavelmente perniciosa; o importante é a lembrança do momento certo e na medida adequada. "A história deve ser colocada a serviço da vida" e não o contrário (NIETZSCHE,1978, p.60).

Ainda, segundo Nietzsche, perdeu-se a relação que deveria subsistir entre a história e a vida. A história tornou-se ciência objetiva e sem interesse que impede suas relações com a vida; sua palavra de ordem tornou-se fiat veritas, pereat vita (seja revelada a verdade, morra a vida). Mas a vida para Nietzsche deve dominar a ciência, porque um conhecimento que destrói a vida destrói a si mesmo.

Os conceitos de conservação com tendência, baseados na memória e na história, foram superados graças às teorias do italiano Gustavo Giovannoni (1873-1947). Ele era um intelectual polêmico em relação aos cânones acadêmicos da época; situando-se entre a análise histórica e o projeto de restauro, impôs uma visão muito ampla do "estudo dos monumentos", que se estende para a totalidade do ambiente urbano circundante. Seu conceito de planejamento urbano estava, de certa forma, em continuidade com 0 pensamento de Riegel, desenvolvendo-se em direção à integração dos saberes e competências diversas do arquiteto e aos diferentes aspectos da cidade que a compõem.

Ele retoma as regras de Sitte sobre a formação do espaço público da cidade observando que ao longo dos séculos os tecidos antigos se adensaram e causaram uma ruptura do equilíbrio da densidade física e social. Porém, Giovannoni critica as teorias de Haussmann acreditando que é necessário ter um certo cuidado em relação aos tecidos pré-existentes para não criar cortes 
no tecido urbano, mas sim percursos que mantêm sua fisionomia e impedem danos causados aos elementos urbanos pelas retificações que freqüentemente provocam $\mathrm{o}$ isolamento dos monumentos e rompem a harmonia urbana herdada da antiguidade.

A partir de 1935, começam a aparecer em revistas especializadas artigos sobre arquiteturas menores. O conceito de arquitetura menor ou vernacular nasce de uma das ramificações do regionalismo e serve para atrair a atenção de estudiosos como Pagano sobre uma série de áreas e de centros abandonados.

O pensamento de Gustavo Giovannoni influenciou, com sua visão italiana, toda a primeira metade do século XX, a ponto de ser adotado na Carta de Atenas de 1933 que também questionou a proteção aos monumentos históricos, embora a questão da preservação das cidades não estivesse ainda em discussão.

Foi somente com Cesare Brandi, nos anos 40 do século XX, que a dialética entre história e estética no restauro seria formulada abertamente. Teórico e crítico italiano de história da arte, Cesare Brandi (1906-1988) criou a teoria da restauração, editada em 1963, distinguindo a restauração de produtos industrializados daquela realizada em obras de arte. A primeira refere-se à recuperação da funcionalidade dos objetos e a segunda tem o objetivo de restaurar a autenticidade material da obra. Leva em consideração seus aspectos estéticos, correspondentes ao senso artístico, e históricos relacionados a uma produção humana de um determinado tempo e lugar, priorizando a estética em caso de conflito. 
No período do pós-guerra, a Europa teve que enfrentar as conseqüências das destruições; na Itália, é adotado o restauro crítico, segundo o qual o monumento deve ter inegável qualidade artística.

Em julho de 1951, a área central, definida como Coração da Cidade, foi tema do $8^{\circ}$ CIAM (Congresso Internacional de Arquitetura Moderna), na pequena cidade de Hoddesdon, próxima a Londres. Naquele encontro, se vislumbraria um processo de diferenciação mais profundo do movimento moderno e as idéias centraram-se na retificação da Carta de Atenas. Citaramse cidades americanas e seus subúrbios, a criação de zonas centrais para pedestres nas cidades inglesas, suecas e holandesas, ressaltando a importância dos centros históricos das cidades italianas. O congresso se propôs individuar maneiras para "humanizar a vida urbana", como nova missão social dos CIAM do pós-guerra. As principais intervenções foram de Sigfried Giedion, com "As Raízes Históricas do Coração"; José Luis Sert e "A Necessidade do Coração"; Le Corbusier, em "O Aspecto Humano do Coração"; Walter Gropius: "A Educação do Arquiteto". O centro urbano passava a ser o elemento caracterizador de uma comunidade, voltado aos seus habitantes (Sert), o repositório da memória da coletividade (Gropius), e o local que possibilitava entender o aspecto comunitário da vida humana (Jacob B. Bakema) ${ }^{6}$.

Entretanto, conforme escreve Michelangelo Russo, foi na Convenção Internacional de Veneza, em 1964, que se marca uma passagem importante para ampliação dos princípios de conservação. Na Carta de Veneza, o documento é essencialmente baseado numa extensão da noção de

\footnotetext{
${ }^{6}$ Os atos do Congresso podem ser encontrados no livro ROGERS, E.N.; TYRWHITT, J.; SERT J.L. Il cuore della città. Milano: Hoepli, 1952.
} 
monumento para a de ambiente, evidenciando o valor das estratificações culturais, que incluíam também obras modestas.

Já a Carta de Amsterdã (1975) estabelece a conservação integrada, isto é, associa os dois conceitos de conservação/restauro e suas atribuições a um uso apropriado. O monumento deve ter uma função compatível com sua natureza e que não comporte modificações violentas ou indiscriminadas. A história nos demonstra como a sobrevivência da arquitetura antiga está diretamente ligada ao seu uso.

O patrimônio histórico passou a ser considerado não apenas como testemunho de gerações passadas que nos transmitem seus valores culturais e de uso, mas também começou a respeitar ou assimilou os valores sociais e econômicos da atualidade.

Deste excursus percebe-se como não somente o conceito de restauro sofreu fortes transformações no tempo sob o influxo das modas, filosofias, acontecimentos políticos e do próprio conceito de arte e de arquitetura, mas também como o profissional denominado restaurador mudou sua postura.

Entre intervalos de admiração, nostalgia e qualquer outro tipo de culto pelas obras do passado, sucederam-se diversos momentos marcados por forte aversão pelos símbolos e monumentos de uma cultura sócio-religiosa precedente, concomitantes a revoluções ideológicas drásticas.

Com a Revolução Industrial, com os novos meios de transporte e, principalmente pelo grande respeito que a ciência suscita no mundo contemporâneo, mesmo a conservação de monumentos percorre caminhos totalmente novos, sem precedentes em épocas passadas. 
Como Jane Jacobs (2000) nota, as cidades são um imenso laboratório experimental, teatro dos falimentos e dos sucessos da construção e da arquitetura urbana.

Podemos assim concluir que o nascimento e a evolução da idéia de patrimônio urbano têm origem na passagem cultural que transforma a cidade material em objeto de saber histórico; tal conversão, pode-se dizer, já aconteceu no fim do Oitocentos, em seguida às transformações da cidade industrial e aos inevitáveis efeitos sobre o espaço urbano devido à desorganização do ambiente tradicional. A cidade antiga, mesmo a colonial, é uma cidade de proximidade e vizinhança, enquanto a contemporânea é feita de intervenções fragmentárias, de subtrações e acréscimos cumulativos que, embora ajam pontualmente e localmente, conseguem dar um novo sentido a todo o complexo urbano.

\section{Mescla de Pessoas e Diversificação de Atividades}

Todo discurso de preservação da memória, da história e da identidade que atravessa o século é posto em xeque pelo tipo, forma e modo de apropriação desses espaços. A reutilização de um bem é a forma mais eficaz para garantir sua preservação, pois um monumento sem uso se deteriora rapidamente. Os poderes econômico e comercial se apropriam do valor cultural; para ser usufruído pela cultura predominante, acabam por desvinculálo de toda a sua rede de relações anteriores.

Segundo Michelangelo Russo (1998), conservar, em primeira instância, significa especificar os valores implícitos nos bens culturais e nas relações 
existentes entre o patrimônio e a cidade, mas significa também individualizar estratégias para a sua manutenção e sua continuidade.

A preservação da cidade deve manter os modos de vida a ela vinculados. A arquitetura vernacular necessita ser considerada dentro do seu contexto, como uma ponte entre a história e a arquitetura, como um sistema contínuo de referências para a transformação e tutela dos valores históricos e culturais e para a formação de uma consciência popular. Visto que muitos edifícios sobrevivem a si mesmos e à sua função, transformá-los é e continuará a ser uma ação importante. Do mesmo modo como é importante transformá-los fisicamente, é importante analisar o conceito e aprofundar seu fundamento lógico.

A recuperação deve considerar os efeitos do re-equilíbrio e transformação em escala urbana e territorial, em conexão com uma ampla estratégia de valores, entre os quais uma mescla bem complexa de usos que requer uma variedade enorme de ingredientes para conferir à cidade a segurança das ruas, os contatos entre os habitantes.

As intricadas misturas de usos diversos nas cidades não são uma forma de caos; ao contrário, elas representam uma complexa e altamente evoluída ordem. De qualquer maneira, fica evidente que as intricadas mesclas de edifícios, usos e visuais são necessárias para a vitalidade dos bairros urbanos. É verdade que as diversidades trazem consigo inconvenientes - que Ihes são atribuídos pela doutrina e literatura urbanísticas - como feiúra, conflito entre os vários usos, e congestionamentos, conforme previsto por Jane Jacobs, entre outros urbanistas. 
Escreve David Harvey (1992), que, atualmente, é norma procurar estratégias pluralistas e orgânicas para a abordagem do desenvolvimento urbano, como uma colagem de espaços altamente diferenciados, ao invés de perseguir planos baseados no zoneamento funcional de atividades diferentes. A cidade-colagem é agora o tema explorado, e a "revitalização urbana" substitui a "renovação urbana" como a palavra-chave do léxico dos planejadores. Em qualquer espaço de território urbano são imprescindíveis serviços diversificados com importância territorial que permitam os intercâmbios com as outras partes da cidade.

A esse respeito, Jane Jacobs escreve que as cidades têm necessidade de usos complexos e diversificados independentes entre si, tanto sob o aspecto econômico quanto social. As zonas doentes são exatamente aquelas nas quais falta esta espécie de complexa inter-independência.

Os centros urbanos nasceram para ter funções. Hoje, é necessário reforçar aquelas funções e aqueles valores, recuperar a ordem natural que mescla os diversos setores: comercial, residencial, laboratórios, escritórios, lojas, equipamentos públicos e privados, também porque esses setores estão ligados a uma dimensão da identidade histórica extremamente diversificada. $\mathrm{O}$ bairro, ou melhor ainda - o maior número possível de zonas que o compõem continua Jane Jacobs, deve servir para muitas funções primárias possíveis, de preferência mais de duas. Estas funções têm de assegurar a presença de pessoas que povoem as ruas em horários diferentes e que, apesar de freqüentarem a região por motivos diferentes, mantenham o mesmo modo de uso de seus equipamentos. 
As ruas sempre asseguraram às cidades uma continuidade sem a qual qualquer bairro poderia pertencer a qualquer cidade. Sempre tiveram grande importância na estrutura e formação das cidades brasileiras como também nas inter-relações entre os cidadãos.

Da mesma maneira, a mistura de usos aos quais são destinados os edifícios reflete-se diretamente em uma variedade de "usuários que entram e saem em horários diferentes, em função de seus trabalhos; o ambiente urbano torna-se uma complexa seqüência de usos e utilizadores" (JACOBS, 2000, p. 88).

Jeudy alerta para o fato de que ao tentar recuperar os centros históricos pode-se fazer uma tábula rasa da região; expulsar a população, mudar a configuração do lugar para atrair um público mais rico, instalar restaurantes etc. Diz ele que poderiam ser feitas as mesmas coisas com a colaboração da população, sem removê-la; com a participação das instituições que ali atuam e com ajuda do governo. A prática hoje consiste em expulsar antes para depois restaurar tudo, embelezando para habitantes mais ricos que aí irão residir (Jeudy, 2001).

Portanto, a extensão do conceito de preservação pode efetivar-se somente a partir da re-interpretação da mescla de atividades, multiplicidade e densidade do ambiente urbano. E esse é o caminho para se efetuar um novo equilíbrio ao desenvolvimento desordenado da cidade e à falta de serviços adequados no plano metropolitano, urbano e local.

Quanto mais uma cidade conseguir misturar em suas ruas, quotidianamente, uma variedade de usos e utilizadores, tanto melhor. Em outras palavras, escreve Jane Jacobs "quanto mais, os habitantes puderem 
animar e manter vivos os parques, de forma espontânea e econômica, melhor será para a cidade" (JACOBS, 1961, p. 103). Os parques, por sua vez, poderão conferir aos seus bairros amenidade e prazer, ao invés de desolação.

A vida coletiva de tipo informal, que se desenrola nas ruas, pode dar apoio a uma vida pública mais formal e organizada. Gastam-se fortunas com a segurança urbana, mas a cidade somente é segura quando se pode encontrar pessoas nas ruas, a qualquer hora.

Resumindo o pensamento de Jane Jacobs, nas nossas cidades temos necessidade de todas as formas de diversidade misturadas entre si de modo que uma mantenha a outra, que a vida urbana possa acontecer de maneira decorosa e construtiva e que seus habitantes possam manter vivas suas diversidades e desenvolver melhor ainda esse particular tipo de sociedade e civilização. Porém, a diversidade urbana nasce na maioria das vezes das atividades de inúmeros indivíduos e organismos privados diversos, animados por idéias e finalidades variadas, que programam e operam fora do quadro formal da intervenção pública. Para se tornarem econômica e socialmente aptos à formação da diversidade e de seu desenvolvimento otimizado, os bairros urbanos deverão possuir eficazes misturas de usos primários, edifícios de idades diferentes e um elevado número de população. "O ambiente urbano é feito de coisas absolutamente concretas", escreve Jacobs (1961, p. 88).

Por se tratar de lugar de mistura e diversificação, a cidade contemporânea é por natureza instável. É a sede de mudanças contínuas que provoca a formação de situações críticas e soluções transitórias dos problemas: casas que viram fábricas, fábricas que se transformam em teatros, 
escolas que viram casas, jardins que se tornam parques, ruas tranqüilas que viram eixos de tráfego intenso.

O fim da modernidade, ressalta Secchi (2000), como já o foi para a cidade antiga, agora é simultaneamente obsolescência e desativação, transformação e reutilização de muitas de suas partes; como a desativação de fábricas, de escolas e quartéis, de molhes, de ginásios esportivos, de estações e pátios ferroviários por terem perdido sua função original. Mescla, diversificação e obsolescência, sucedendo-se, destroem valores posicionais ${ }^{7}$ e continuamente propõem novos problemas culturais, quer digam respeito aos graus de tolerância, compatibilidade e incompatibilidade em relação ao outro, a suas práticas, a seus usos e atividades, aos ruídos, aos odores, quer se refiram às temporalidades sobrepostas e entrecruzadas.

\footnotetext{
${ }^{7}$ Roy Harrod, um importante economista inglês, para indicar, em termos mais neutros, que o valor de um bem ou de um serviço pode depender não só de sua raridade ou de seu custo de produção, quanto de sua posição na sociedade ou na cidade, fala de valores posicionais. Ver Secchi, B., 2000, p. 81.
} 


\section{Estudo de Casos}

Os casos propostos aqui apresentam elementos que têm forte relação com os temas tratados. Compreendem a importância da arquitetura vernacular para o genius loci da cidade e para reforçar a cidadania; a reconversão e recuperação de áreas de obsolescência industrial que interagem com a complexa estratégia de conservação urbana; a importância dos traçados históricos e do espaço metavernacular como memória coletiva; os tecidos mistos sob a ótica da mescla de pessoas e diversificação de atividades; a questão do espaço público e privado e como eles atuam no espaço semipúblico ou intermediário. 


\section{Milão}

A cidade de Milão contemporânea situa-se em um contexto onde convivem diferentes realidades, todas facilmente reconhecíveis e potencialmente expressivas, que partem da sua formação romana, com 0 centro medieval, os burgos lineares, os pequenos municípios anexados (mas não aniquilados), a malha viária do século $\mathrm{XIX}$, a cidade industrial até as periferias do século XX.

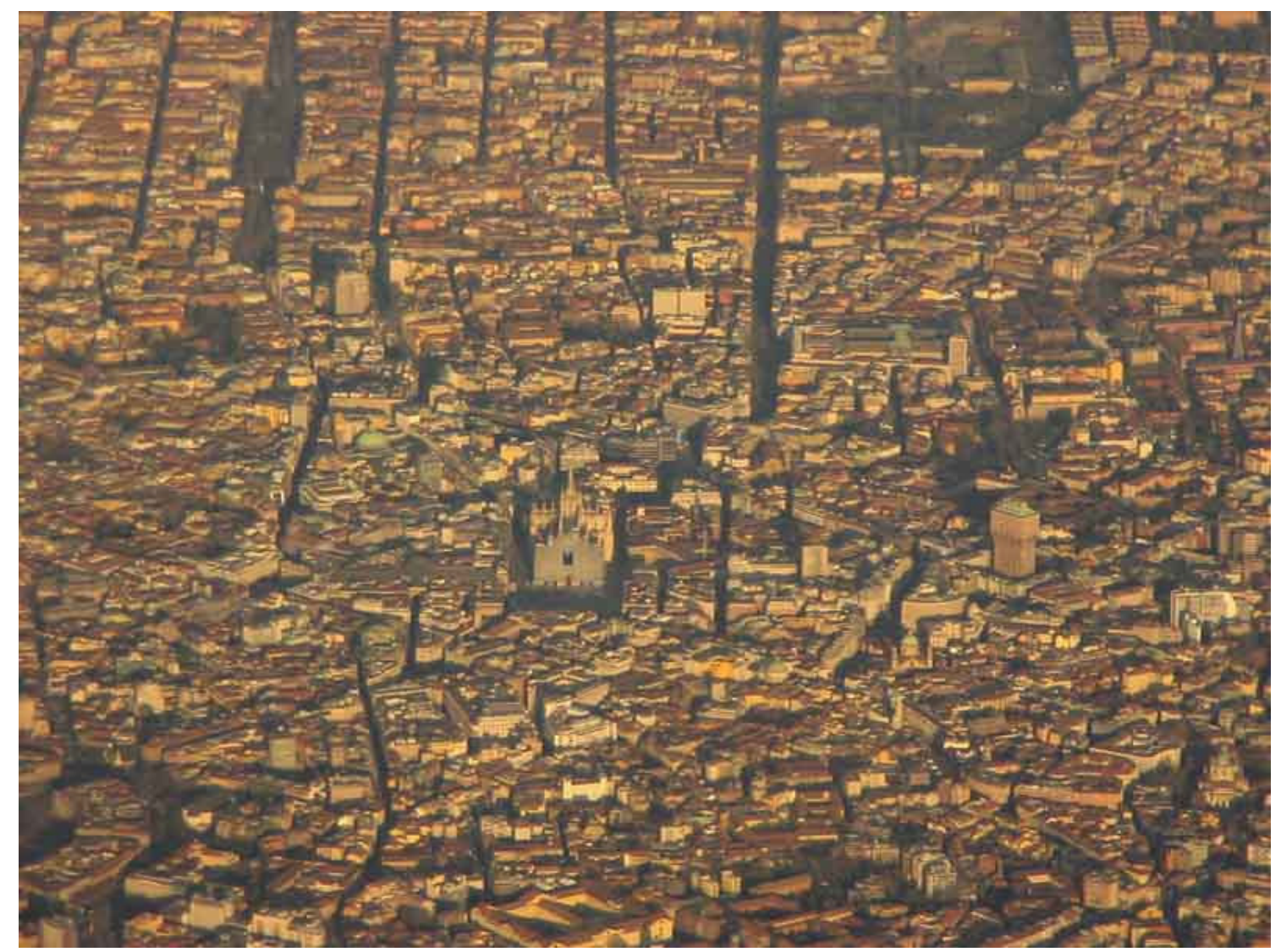

Fig. 28 - vista aérea do Duomo e do centro de Milão

Milão é a capital econômica da Itália pela riqueza e pelos benefícios que produziu para seus habitantes. É diferente em relação às outras cidades italianas, até mesmo de Roma, mais atrasadas econômica e socialmente, ainda 
provincianas e com resquícios da mentalidade camponesa, alimentada e reforçada durante o fascismo.

Milão, como São Paulo para o Brasil, é a cidade que conduz a Itália por ter se tornado o centro financeiro e por determinados aspectos culturais. Hoje, ela é a força motora do país.

Suas origens datam do IV e V século a.C. com a migração dos celtas e gálios. A localização estratégica na encruzilhada das vias de comunicações terrestres e fluviais, entre Veneza, Gália, Espanha e Roma, deu origem ao nome Mediolanum, do qual derivou Milano.

Em 194 aC, Milão, já então rica e potente, é conquistada pelos romanos; de suas primeiras muralhas, construídas em meados do século I a.C., origina-se a cidade concêntrica em redor da qual ela foi crescendo até

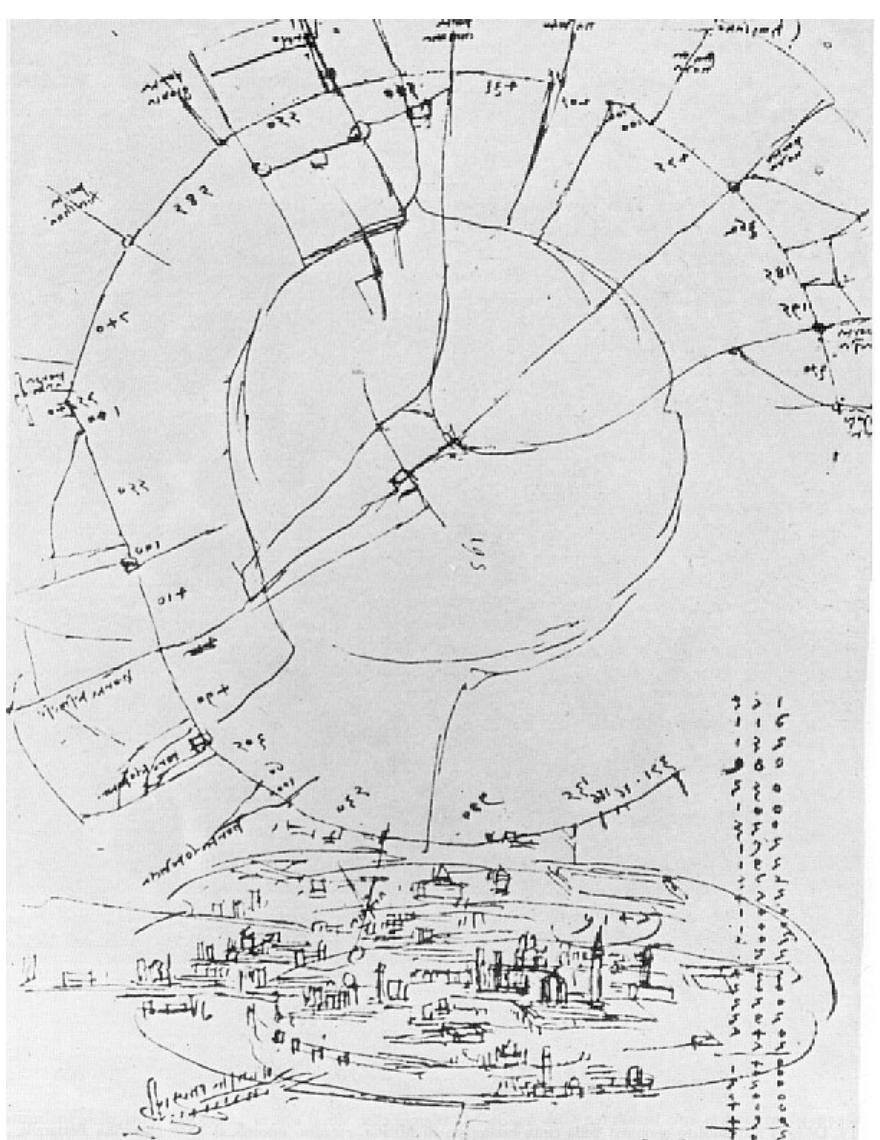

Fig. 29 - Desenho esquemático de Leonardo Da Vinci para Milão - 1497 nossos dias. No fim do século III, ela se posiciona como a segunda cidade em importância da Europa, atrás de Roma.

\section{No século $X V$, a} cidade se caracteriza pela ampliação dos canais e dos cursos de água, originados com a finalidade de defesa, para fornecer água e energia necessárias à vida da cidade e às atividades artesanais. Em 
meados do século $\mathrm{XV}$, desenvolve-se, com a colaboração de Leonardo da Vinci, um sistema inovador de represas e comportas para permitir a comunicação entre canais de níveis diferentes e de interligação da cidade com o lago de Como. Mais tarde, Napoleão III amplia essa rede de comunicação criando uma conexão indireta com o mar ao interligar entre vários rios e lagos do norte da Itália. Mas essa forma de transporte fluvial decai na segunda metade do séc. XIX devido à lentidão nas viagens e, principalmente, à concorrência da ferrovia. Mais tarde, a navegação se ressente principalmente com o progressivo aumento de automóveis; boa parte dos canais são cobertos entre 1929 e 1930, durante o período fascista.

A partir do século XVI, Milão é dominada por espanhóis austríacos e franceses. Cartografias de meados do século XVIII mostram uma cidade substancialmente igual à do século anterior: o tecido é mais denso de construções e localizado próximo às muralhas romanas (também chamadas de republicanas) enquanto que as "espanholas" - construções iniciadas em 1535, durante os 170 anos da ocupação espanhola - constituem um limite físico e administrativo da cidade. Esta área rarefeita será saturada somente em meados do século XIX (BELSKI; MONTRUCCOLI, 2002).

Em 1796, Napoleão Bonaparte invade Milão e expulsa os austríacos, dando início a uma série de infra-estruturas que permite à Itália uma comunicação direta com a França. Milão se afirma cada vez mais como um cruzamento de vias de ligação da Itália para a Europa.

A expulsão dos austríacos e a subseqüente proclamação da Unidade Nacional da Itália, em 1861 - a Itália não existia até aí como nação, ela era uma somatória de cidades - determina o desenvolvimento ferroviário da 
Região Lombarda, impedido antes pelos invasores. A realização da galeria Vittorio Emmanuele II e a organização da Praça do Duomo reforçam o monocentrismo da cidade, relegando a um segundo plano as relações com os territórios limites.

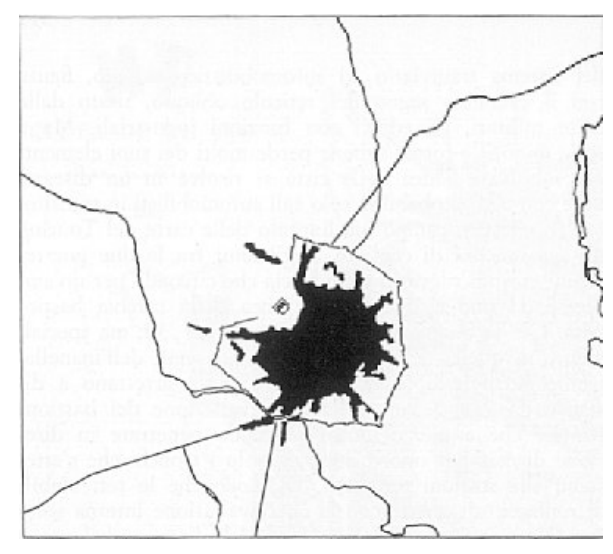

$1800-110$ mil habitantes dentro dns murns esnanholas

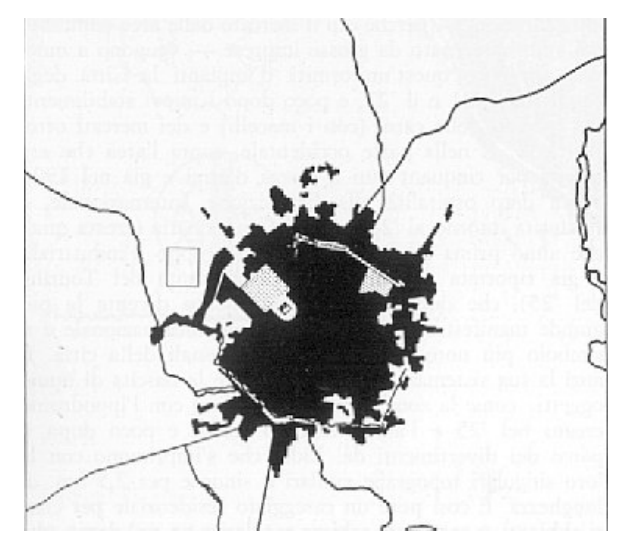

1900 - 490 mil habitantes

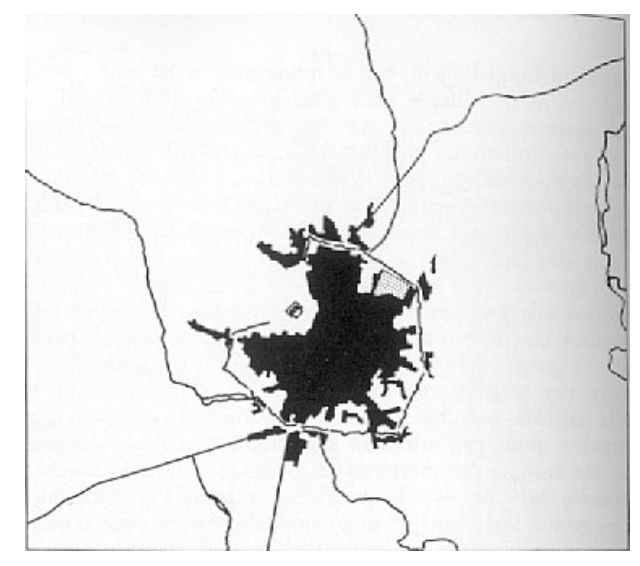

1860 - 185 mil habitantes incluindo sı ı́írhins

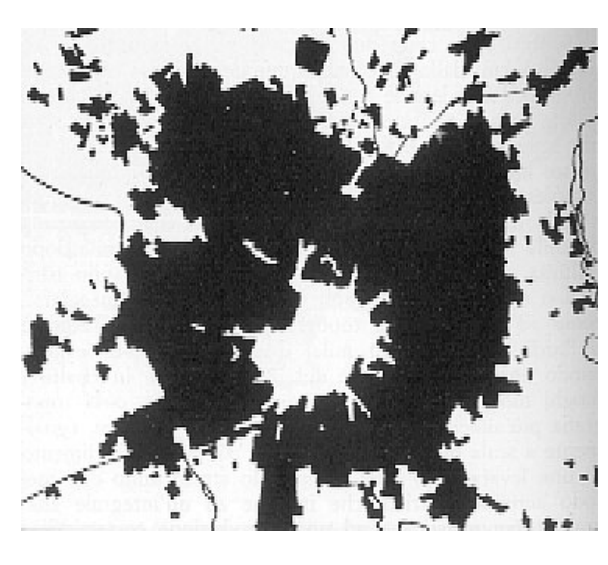

1940 - 1 milhão e 300 mil habitantes

Fig. 30 - Milão, seqüência da dilatação urbana 1800 - 1940

Em uma análise de planos e projetos para a cidade de Milão Moderna e Contemporânea, as arquitetas e pesquisadora M.P. Belski e S. Montruccoli em seu livro "Milano, da posta per cavalli a città regione" afirmam que, ao contrário de Paris com Haussmann (1853) e Barcelona com Cerda y Suňer (1859), em Milão não foi criado nenhum projeto de reurbanização e desenvolvimento. A estrutura existente se adaptou ao novo modo de vida da cidade industrial sem 
conflitos com o pré-existente, ao contrário, tenta-se fortificar a cidade histórica. Só em 1953 ocorre a aprovação de um plano regulador muito esquemático para resolver rapidamente as devastações da Segunda Guerra.

No início do século $X X$, a expansão industrial, em

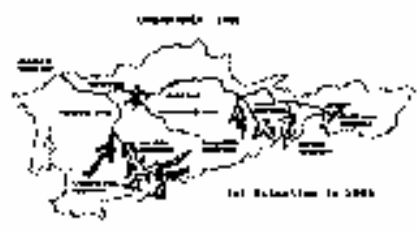
apenas dez anos, faz com que a população radicada junto às muralhas espanholas se reduza, mas fora delas 0 povoamento praticamente duplica,

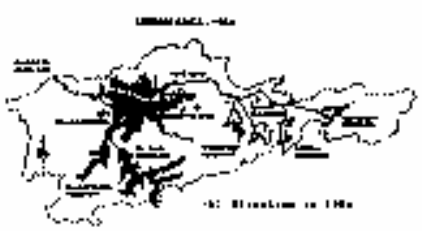
principalmente ao longo do eixo norte-sul de interligação com o resto da Europa.
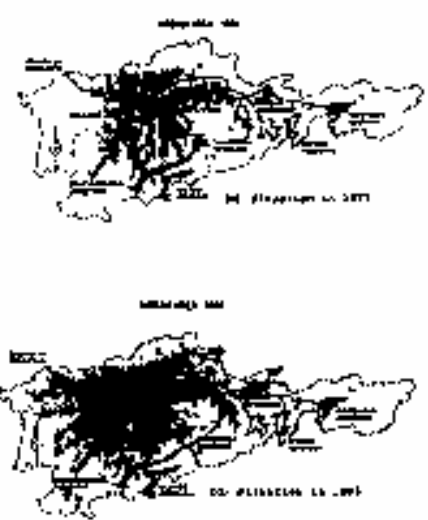

Entre 1921 e 1936, período fascista, foram Fig. 31- Expansão urbana de São Paulo 1905, 1930, 1954, 1985.

demolidos inteiros quarteirões milaneses para dar monumentalidade a certos edifícios ou para criar novas perspectivas. O centro torna-se desestruturado pela abertura de novas ruas e pelas construções do metrô; nos vazios resultantes são edificados prédios para o setor terciário. Além disso, aumentam-se diversos andares nos edifícios existentes dentro das muralhas republicanas, com a conseqüente alteração das relações dos telhados e do tipo de construção, embora o alinhamento dos edifícios com a rua e o formato do quarteirão se mantenham (BELSKI; MONTRUCCOLI, 2002).

Com a lei de Urbanismo Nacional de 1942 - a população então com cerca de 1,2 milhão de pessoas - criam-se as "zonas", que permanecem até hoje. Isto é, a cidade divide-se em áreas autônomas em relação à Prefeitura; nada mais do que uma forma de descentralização, cuja competência, entre 
outras, é a aprovação de todo e qualquer projeto, incluindo reformas internas nos edifícios a até unidades imobiliárias.

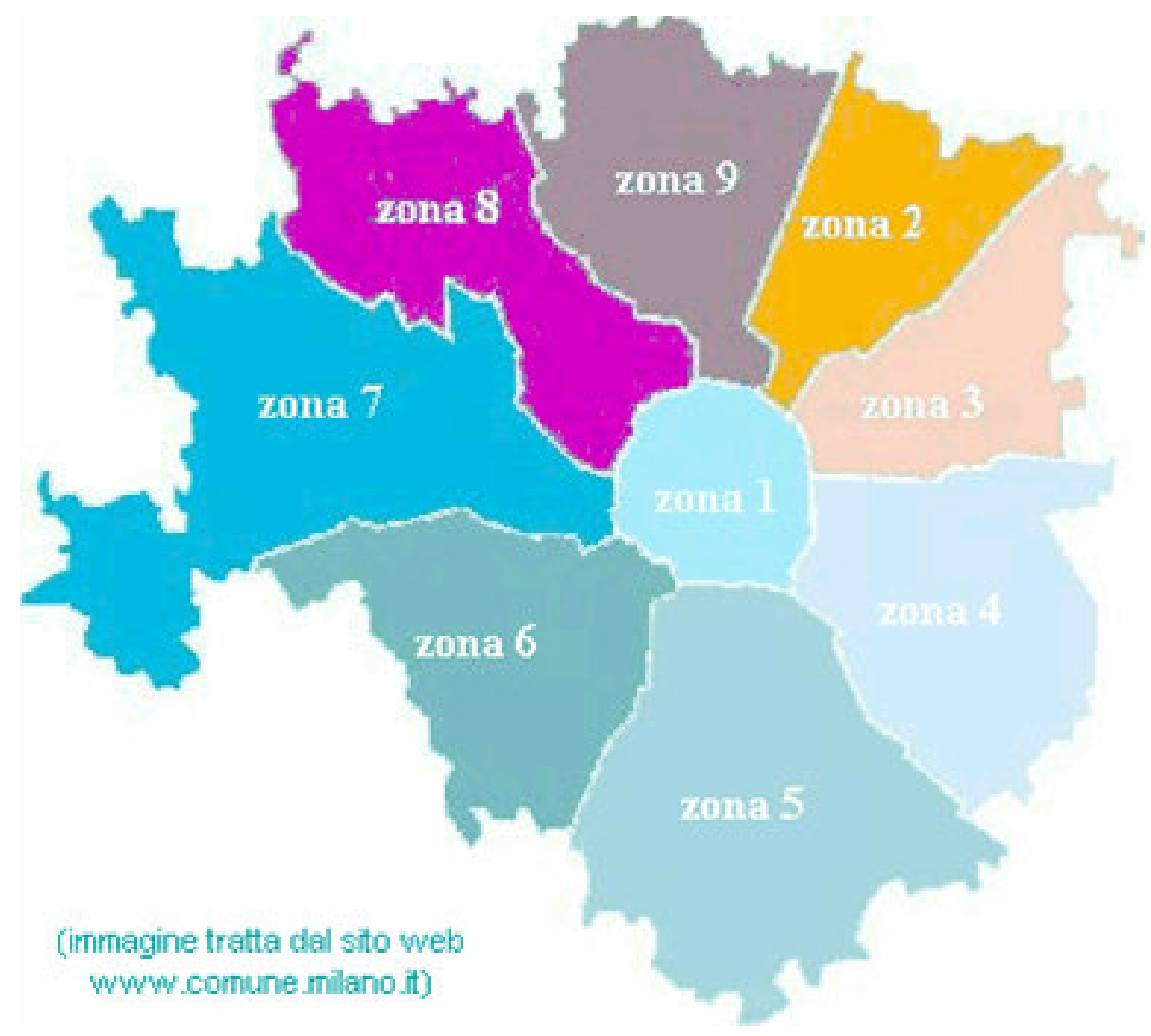

Fig. 32 - Divisão da cidade de Milão em zonas - 2000

Nos anos de 1960, aumenta a especulação urbana do "existente", isto é, torna-se comum demolir todo o interior de um edifício de caráter histórico e artístico mantendo só a fachada. Para frear os abusos, alguns anos depois, instituem-se os Conselhos de Zona, cuja participação direta dos moradores gera um controle de vizinhança, evitando assim obras abusivas "dentro" do edifício ou da própria unidade imobiliária. 


\title{
A Arquitetura Moderna na Itália
}

\begin{abstract}
À arquitetura italiana faltaram, na segunda metade do século passado, os impulsos sociais e econômicos que, nos países da Europa central e setentrional, abriram o caminho à renovação dos processos construtivos e colocaram as premissas do urbanismo e da edificação moderna (ARGAN, 2001, p. 175).
\end{abstract}

No que concerne à arquitetura milanesa, o único movimento de vanguarda de certa importância consiste no Futurismo, oficialmente nascido em Milão em 1910 com poeta italiano Filippo Tommaso Marinetti, e concretizado em 1914, pelo o "Manifesto da Arquitetura Futurista" de Antonio Sant'Elia, (Argan, 2001; Belski, 2002) que proclama a necessidade de uma profunda renovação formal, embora afirmasse que a arquitetura "devia permanecer a todo custo arte e beleza". (Argan, 2001, p.177)

Com a morte de Sant'Elia, em 1916, a atmosfera que se respira na Itália era a da academia, não só na arquitetura mas na pintura também com o retorno de um novo classicismo. Voltados para um enfoque Moderno se destacam os arquitetos Giuseppe

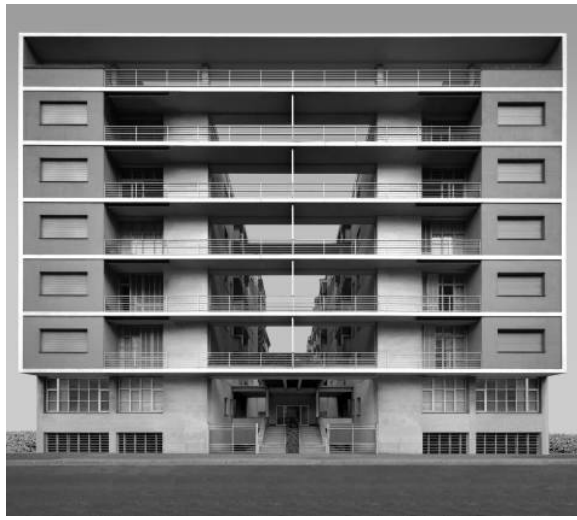

Fig. 33 - Terragni - Casa Rustici, Milão, 1935 Terragni e Giuseppe Pagano. O primeiro, ligado a uma sutil critica do racionalismo europeu; o segundo, por uma arquitetura humana, historicamente determinada pelos problemas vitais da sociedade moderna. Edoardo Persico, mestre de Pagano, contrário à arquitetura monumental oficial do fascismo que então se produz na Itália e, particularmente em Milão, "é o primeiro a compreender que a arquitetura moderna não nascia com o cubismo, ou teria morrido, engatinhando, com Le Corbusier. Mas no 'sulco do Impressionismo'; e 
Wright pode ser considerado o Cézanne da arquitetura nova“. (Argan, 2001, p.205). Segundo Giulio Carlo Argan esta é a única idéia válida expressa na Itália ou fora dela em torno da arquitetura moderna.

É somente depois da Segunda Guerra Mundial, que se determina na Itália um movimento concreto rumo à arquitetura moderna; entre 1950 e 1960, Milão apresentou uma das mais valorizadas arquiteturas da Europa, graças a profissionais como Giò Ponti, Caccia Dominioni, Giuseppe Teragni, Studio BBPR (Banfi, Belgioioso, Peressutti, Rogers), Luigi Figini, Gino Pollini, entre outros.

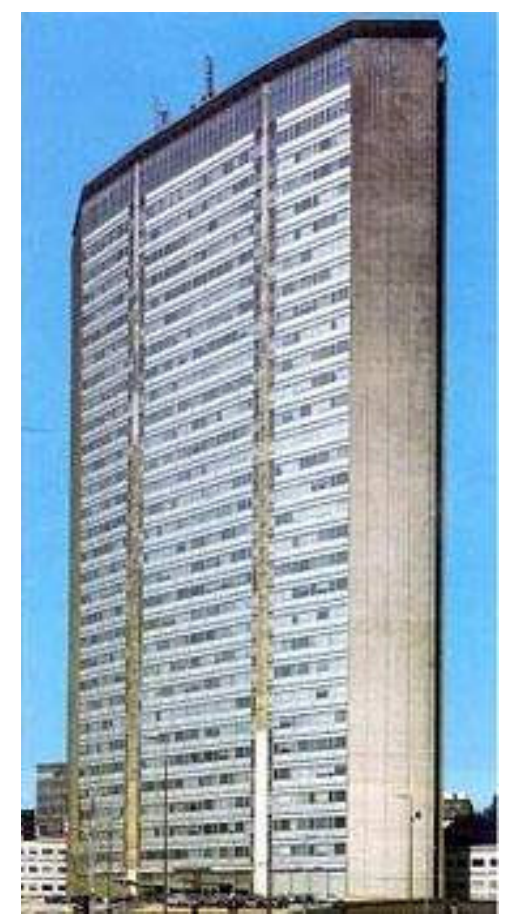

Fig. 34 - Edifício Pireli - arq. Giò Ponti $1955-1960$

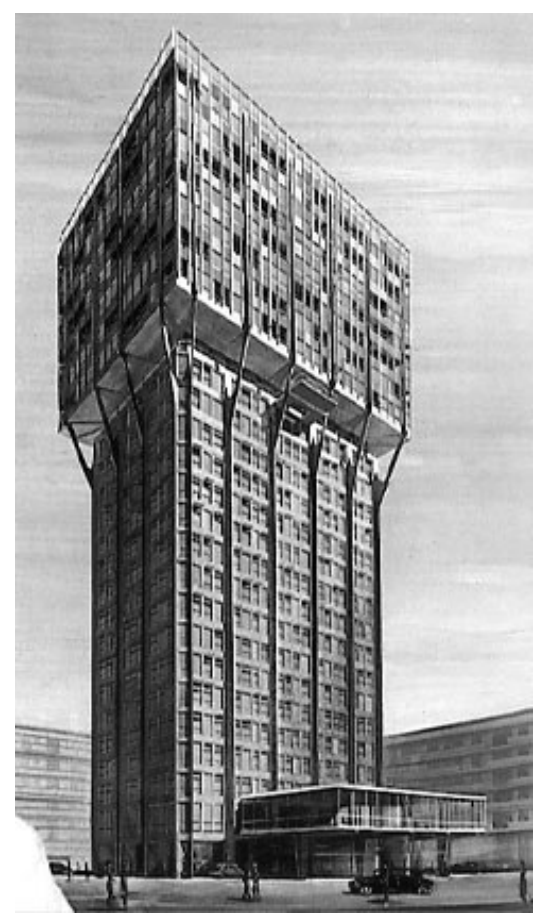

Fig. 35 - Torre Velasca projeto BBPR 1957/59

Nesse período, a arquitetura milanesa estava dividida entre a fidelidade ao movimento moderno internacional e a busca de novos ideais, em continuidade com a história, e que exprimissem os conceitos de consciência 
histórica, tradição e importância do sítio, expostos por Rogers na expressão preesistenze ambientali (pré-existência no ambiente) por ele criada.

Entretanto, entre os anos de 1970 e de 1990, a cidade passa por período obscuro em função de ideais políticos, principalmente da esquerda, abrindo mercado de trabalho para arquitetos "menores". O debate somente ocorria no âmbito da Universidade de Arquitetura, com Aldo Rossi, Gae Aulenti, Vittorio Gregotti, pouco apreciados na Itália em razão do forte tradicionalismo no país. 
Projeto de Recuperação Edifício de Via Bramante em Milão (1996-1999)

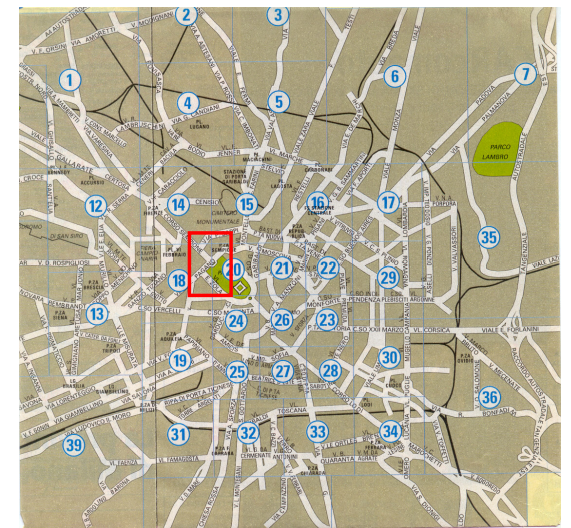

Fig. 36 - Milão, com localização da via Bramante, 2002

O edifício de via Bramante é uma típica estrutura arquitetônica vernacular da Lombardia, chamada na língua original de casa de ringhiera. Estas construções surgiram em meados do séc. XIX, reproduzindo modelo das

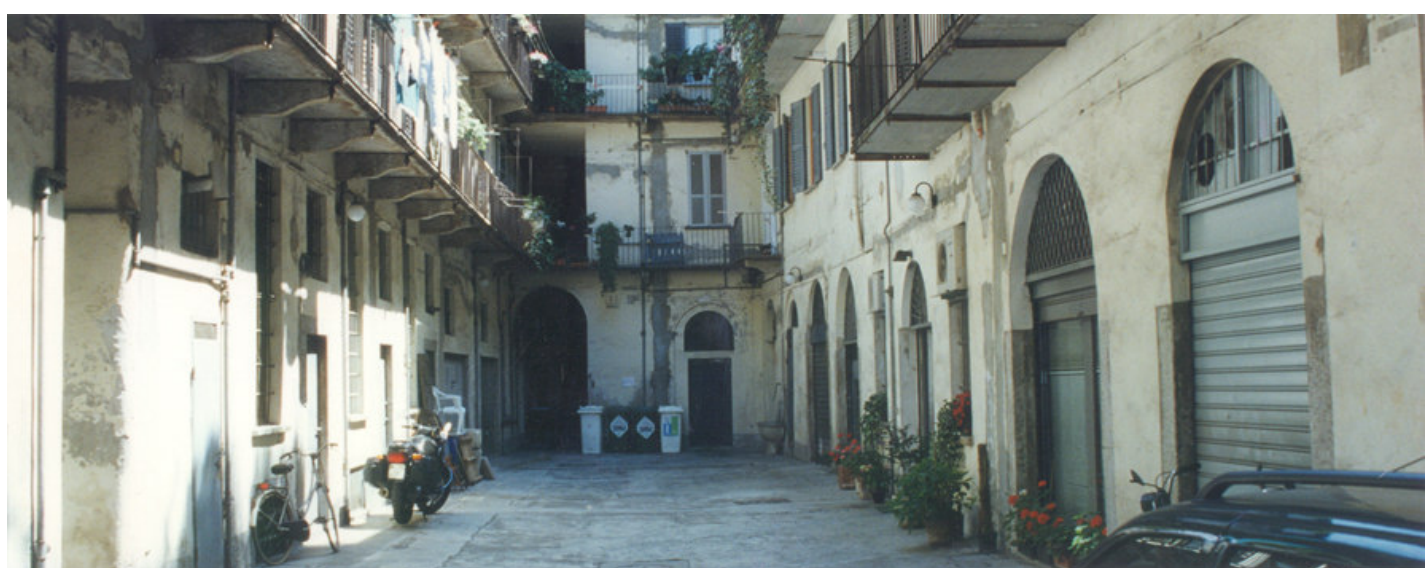

Fig. 37 - edifício da via Bramante pouco antes das obras de recuperação, 1996.

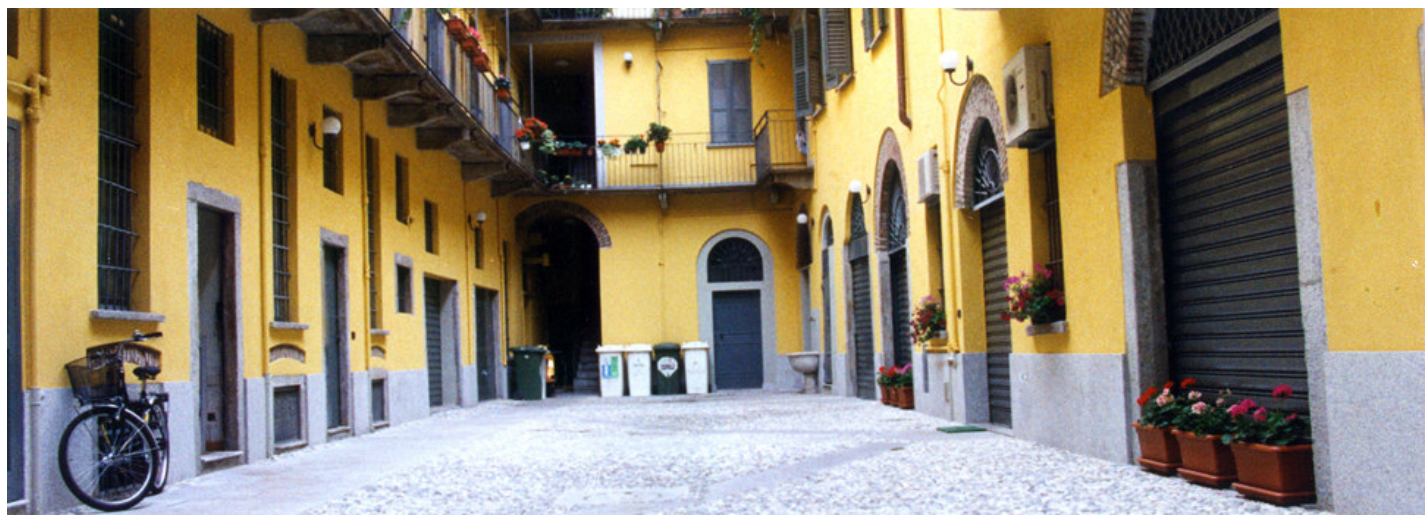

Fig. 38 - edifício da via Bramante após as obras de recuperação, 1999. 
casas rurais, principalmente junto às portas da cidade embora sejam também numerosas em áreas centrais, nas proximidades de pequenas industrias. Este tipo de habitação, construído como apartamentos de aluguel destinados à classe operária e a pequenos artesãos, constitui uma amostragem da vida popular de então.

A casa popular milanesa, a clássica casa de ringhiera, caracterizava-se não só pelo pátio interno e uma fonte central para lavagem de roupas, mas por ringhieras ou ballatoi, ou seja, terraços

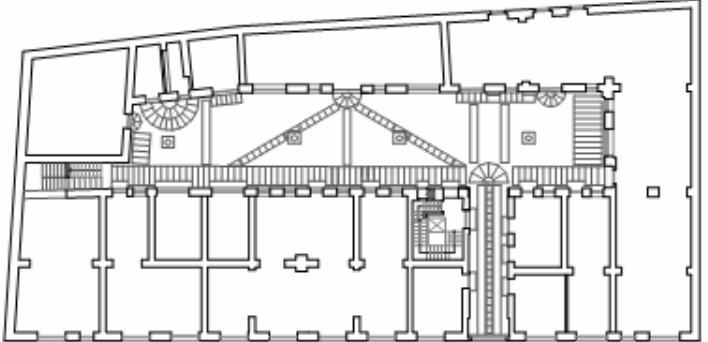

Fig. 39 - Ed. via Bramrante Planta térreo

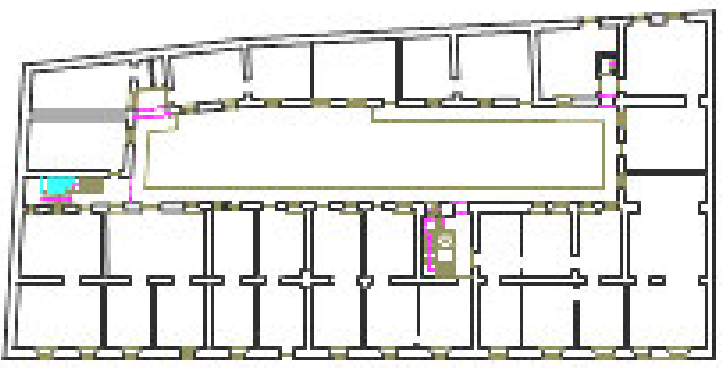

Fig. 40 - Ed. via Bramante Planta $1^{\circ}$ andar com um metro de largura no máximo, que percorriam todos os pavimentos ao redor do pátio e por onde se tinha acesso aos apartamentos. Essas habitações eram compostas por dois quartos, de $4,20 \times 4,20 \mathrm{~m}$ cada; um, voltado para o pátio interno, era a zona diurna, usada para cozinhar, comer, ler, ou conversar; o outro, com janela

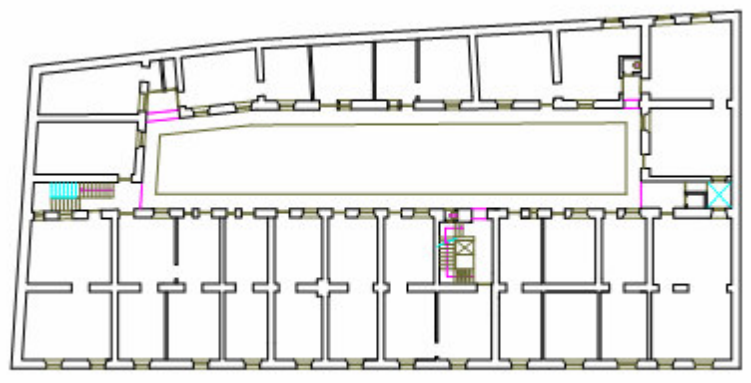

Fig. 41 - Ed. via Bramante Planta $2^{\circ}$ andar

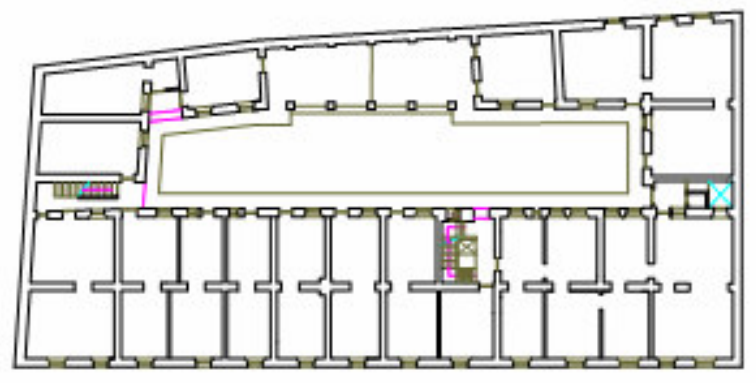

Fig. 42 - Ed. via Bramante Planta $3^{\circ}$ andar 


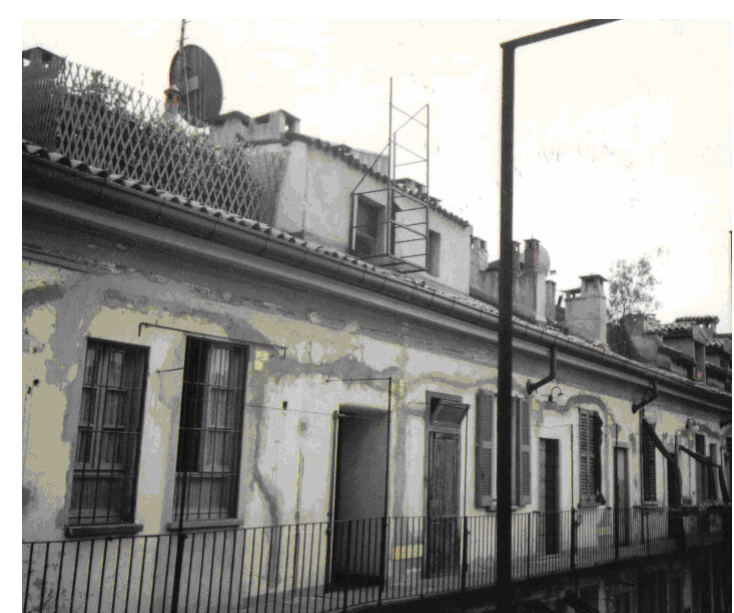

Fig. 43 - Ed. via Bramante pouco antes das obras de recuperação, $3^{\circ}$ andar.

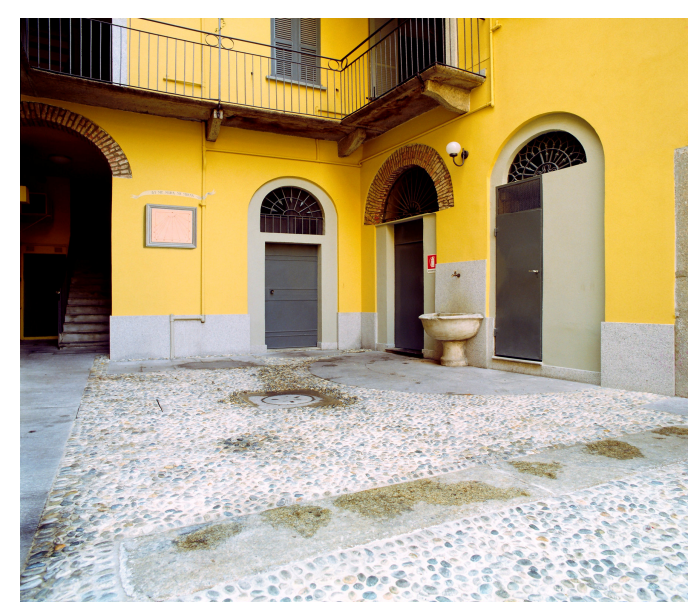

Fig. 44 - Ed. via Bramante após as obras de recuperação, local para lavagem de roupa.

para a rua, era destinado ao repouso. Em muitas dessas casas não existia água corrente. Os banheiros de uso comunitário estavam localizados no ballatoio e os apartamentos eram aquecidos com carvão. O espaço era um luxo e estes apartamentos eram ocupados por famílias de cinco a sete pessoas. $\mathrm{O}$ andar térreo, como as bodegas medievais, em geral era usado para oficinas, estrebarias, secagem de salames ou engarrafamento de vinhos. Somente os que tinham acesso direto à rua ficavam abertos ao público.

As casas de ringhiera revelam como se entrelaçavam os diferentes aspectos do quotidiano, visto que muitas ocupações se desenvolviam em público, principalmente no pátio que representava o centro de atividades das famílias residentes.

Com o passar dos anos e a chegada de novas tecnologias com máquinas de lavar roupa, fogão a gás, aquecimento centralizado, o desmembramento da propriedade de um único dono para vários, a subdivisão das unidades e sua transformação em condomínio, com o crescente aumento da renda 


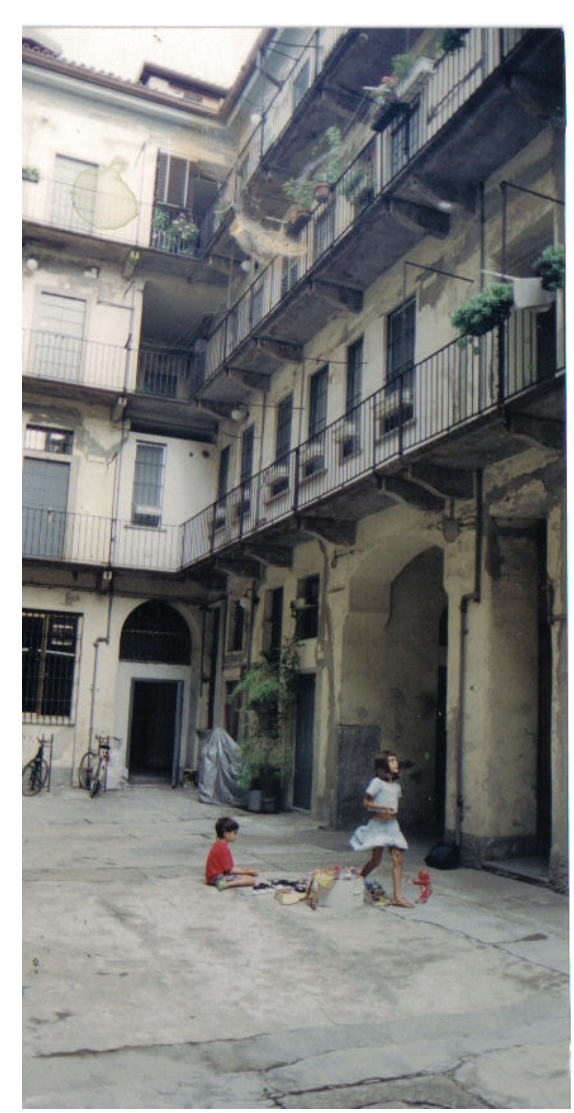

Fig. 45 - Ed. via Bramante pouco antes das obras de recuperação, 1996.

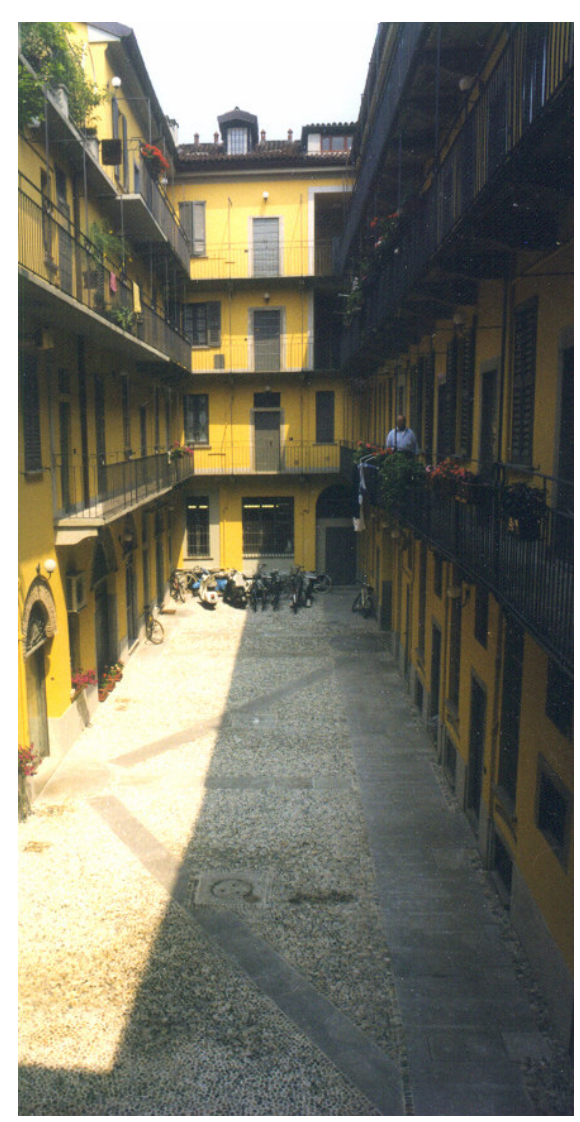

Fig. 46 - Ed. via Bramante após as obras de recuperação, 1999.

individual, provocaram sérias modificações nos apartamentos. As atividades comunitárias de então foram substituídas por outros aspectos da sociedade contemporânea, visto que o pátio de espaço privado torna-se semipúblico.

O edifício de via Bramante resulta de sucessivas edificações iniciadas em meados do séc. XIX, em função da pequena fábrica de tabaco localizada em suas proximidades. No início do século XX, a construção de outro edifício de ringhiera altera a conformação original do grande pátio quadrado, destinando metade desse espaço para cada um dos prédios. Não existem, porém, documentos precisos que identifiquem esse processo.

A obra em questão é apenas um exemplo entre centenas de outros edifícios vernaculares com as mesmas características que, como toda obra de 
importância estética ou simplesmente histórica, por força das circunstâncias torna-se objeto de transformação, de adaptações, de reconstruções.

Esta tipologia típica milanesa inspirou Aldo Rossi no projeto do Gallaratese, em que a construção toda se desenvolveu ao longo de uma galeria ou passagem a ballatoio. Constata-se, portanto, que o passado e

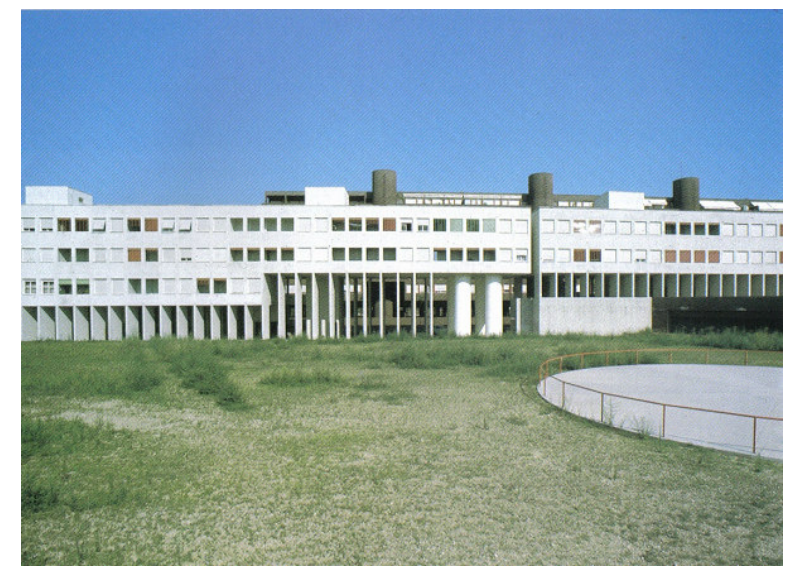

Fig. 47 - Edifício habitação popular Gallaratese (1967-1972) projeto arq. Aldo Rossi. o estilo local propõem as fórmulas da arquitetura moderna, e "a galeria se torna uma rua interna elevada". (ROSSI, 1984, p. 25) resultando em uma "construção que se realiza na manipulação consciente dos elementos da arquitetura" (MONEO, 2004, p. 50).

É evidente também a relação tipológica que Gregotti faz com as casas de habitação popular da Bicocca; ele respeita a planta interna com dois ambientes, modernizando-a com banheiros e cozinha, mas mantendo a dupla relação de janela/pátio, janela/rua; respeita o aspecto externo das casas de ringhiera mas não parece preocupado com a liberdade que utiliza os elementos caracterizantes, em que o ballatoio se torna privado, os pátios se abrem para 0 entorno, o tipo é reduzido à imagem. Na realidade, a identificação de um tipo, neste caso a ringhiera e o pátio - elementos familiares ao milanês - segundo Moneo (2004), pode ser a maneira com a qual o arquiteto pode estabelecer relações sólidas com a sociedade; 


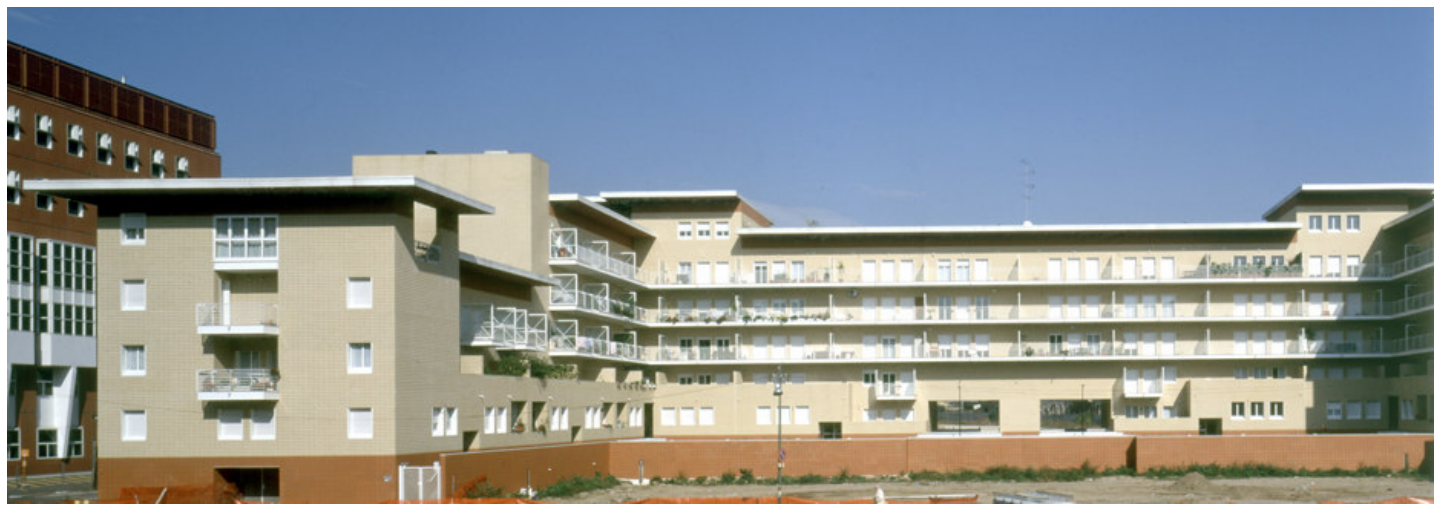

Fig. 48 - Edifício habitação popular na Bicocca (1999) projeto arq. Vittorio Gregotti.

A Via Bramante, hoje, encontra-se em bairro extremamente central, junto às primeiras muralhas (romanas ou republicanas); a estrutura econômica e social de seus ocupantes é diferente e varia, apesar de que, em 1999, época de sua recuperação, ainda existiam apartamentos com a mesma estrutura original e moradores que aí viviam nas mesmas condições de quando foi construído o edifício, sem banheiro ou aquecimento.

A população operária foi expulsa e substituída por uma classe média e média/alta, mas isso não ocorreu devido à re-qualificação do edifício. O processo vem de mais longe, da mudança da sociedade moderna em um primeiro momento e, depois, com a cidade contemporânea. O próprio centro histórico mudou como mudaram as condições de comércio e de economia também.

Hoje as casas de ringhiera são particularmente caracterizadas pela presença de diversos grupos sociais e etnias diferentes. O edifício adquire assim significado urbano, tal qual um pedaço de cidade pela presença de escritórios, lojas e atividades abertas ao público, localizados no térreo - tanto aqueles com acesso direto à rua, quanto os com acesso somente pelo pátio que substituíram oficinas ou estrebarias. 
Atualmente, no edifício de Via Bramante, poucos apartamentos mantiveram a estrutura original: foram reformados pelos proprietários que reuniram vários módulos, criando unidades de várias dimensões das 70 residências e 26 espaços comerciais, passaram respectivamente a 30 residenciais e 11 comerciais; foram acrescentados aquecimento, cozinhas e banheiros. Isto implicou em modificação nas instalações hidráulicas, elétricas, telefônicas, de esgoto, gás individual, sem nenhum planejamento na estrutura do prédio - dando ao edifício um aspecto extremamente degradado.

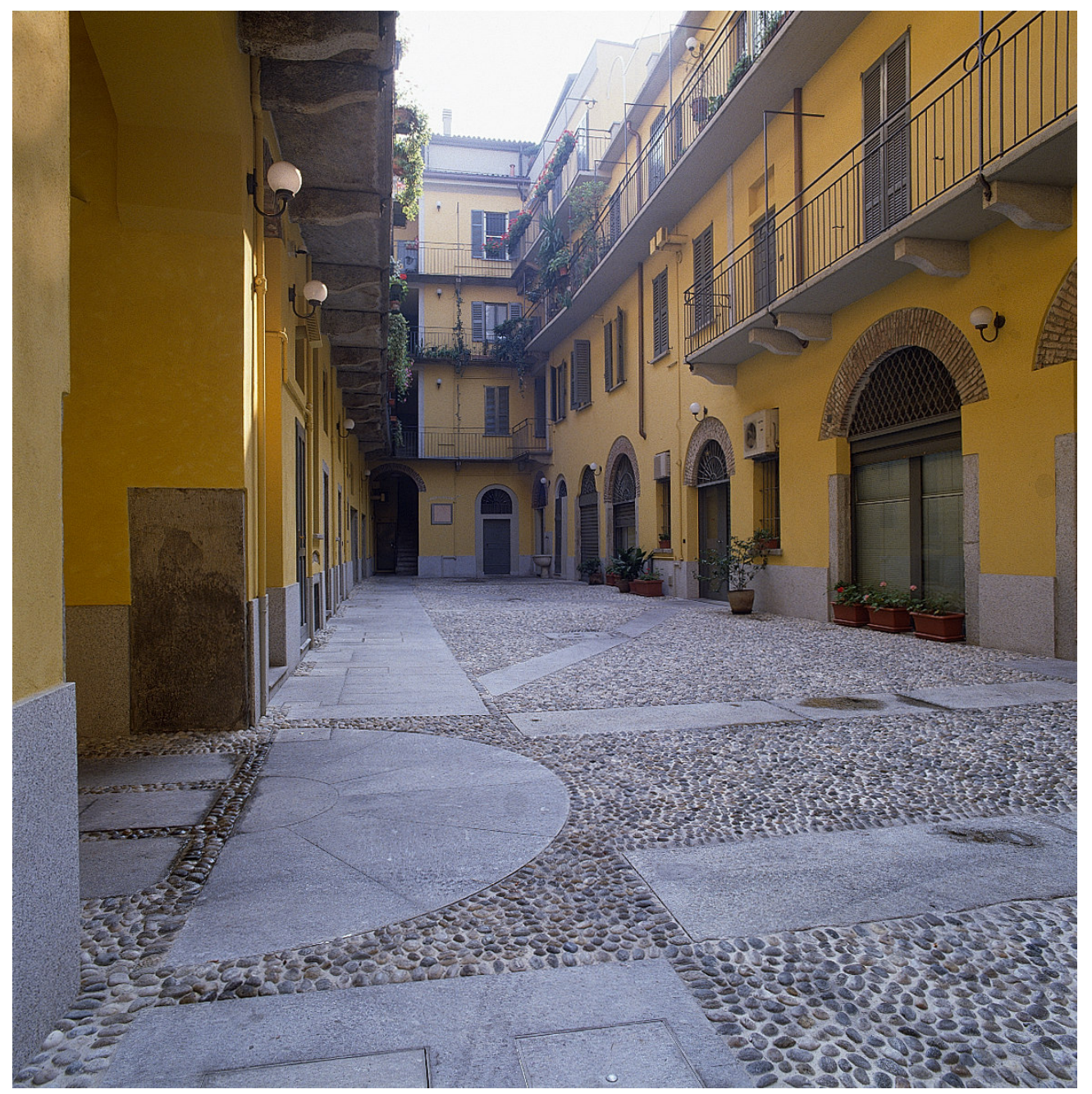

Fig. 49 - Vista do edifício de via Bramante apos as obras de recuperação.

Em Milão e na Itália em geral, os edifícios não são tombados um a um seguindo critérios de valor arquitetônico que podem ser facilmente 
contestados. A cidade é considerada como um todo, com a sua formação histórica e arquitetônica que caracterizam seu genius loci. Todos os edifícios considerados "históricos" mesmo sem importância arquitetônica significativa, não podem ser demolidos a não ser que atinjam níveis de degradação com um risco estrutural grave. E existem normas da prefeitura muito rígidas para a restauração destas construções.

O Via Bramante, é considerado um edifício com vínculo histórico ao qual a população atribui um valor particularmente elevado; para sua recuperação respeitaram-se as normas da prefeitura e mantidas as características das Casas de ringhiera Vecchia Milano com a cor, estrutura e simplicidade dos elementos componentes e decorativos: deu-se porém uma nova imagem ao edifico com particular atenção aos detalhes que introduziram uma relação de continuidade entre os diversos tipos e elementos. 


\section{Area Pirelli - Bicocca (1984 - 2006)}

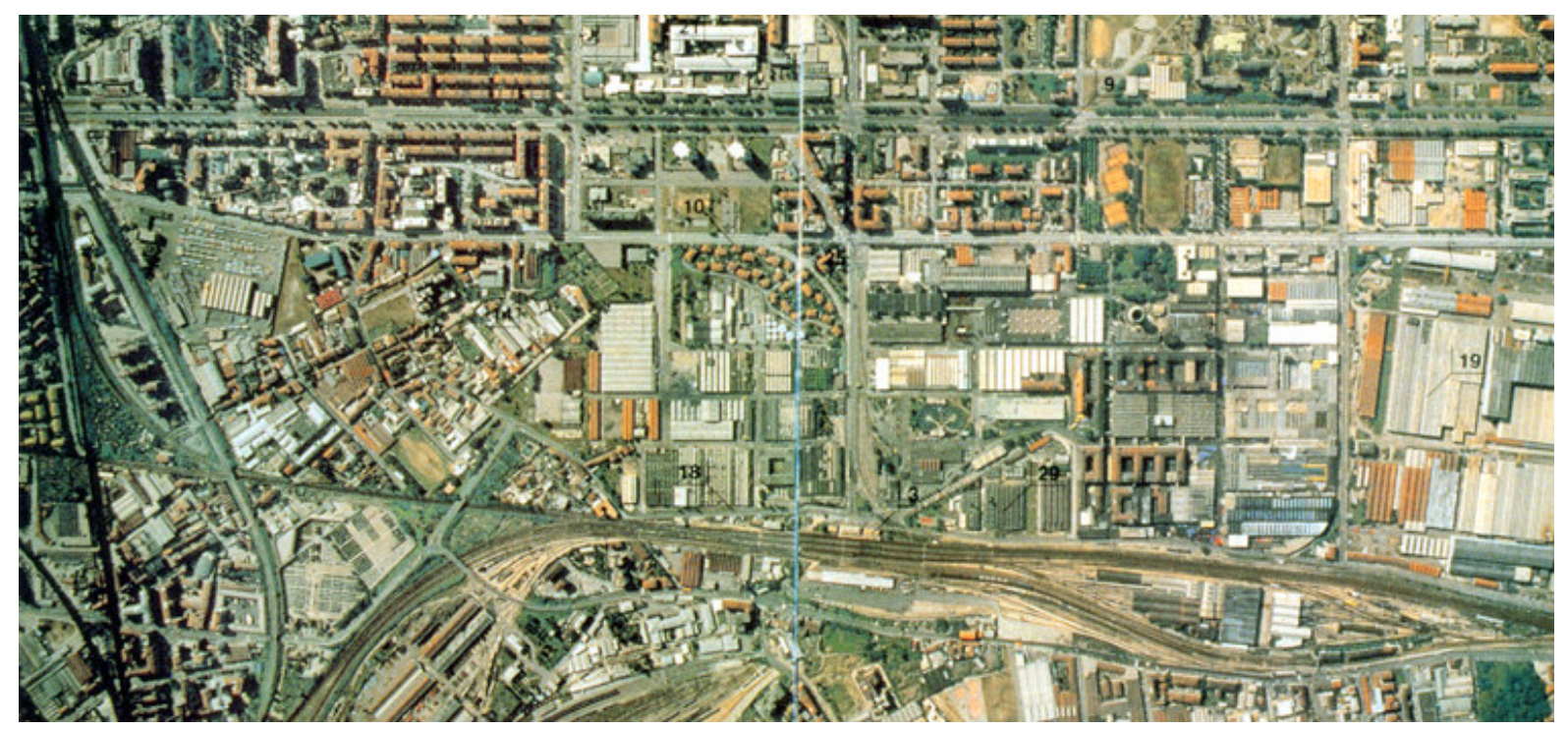

Fig. 50 - Foto área da área Bicocca antes das obras, 1984.

O projeto de intervenção em Bicocca, antiga área industrial da Pirelli, constitui uma das intervenções urbanas mais amplas e significativas realizadas
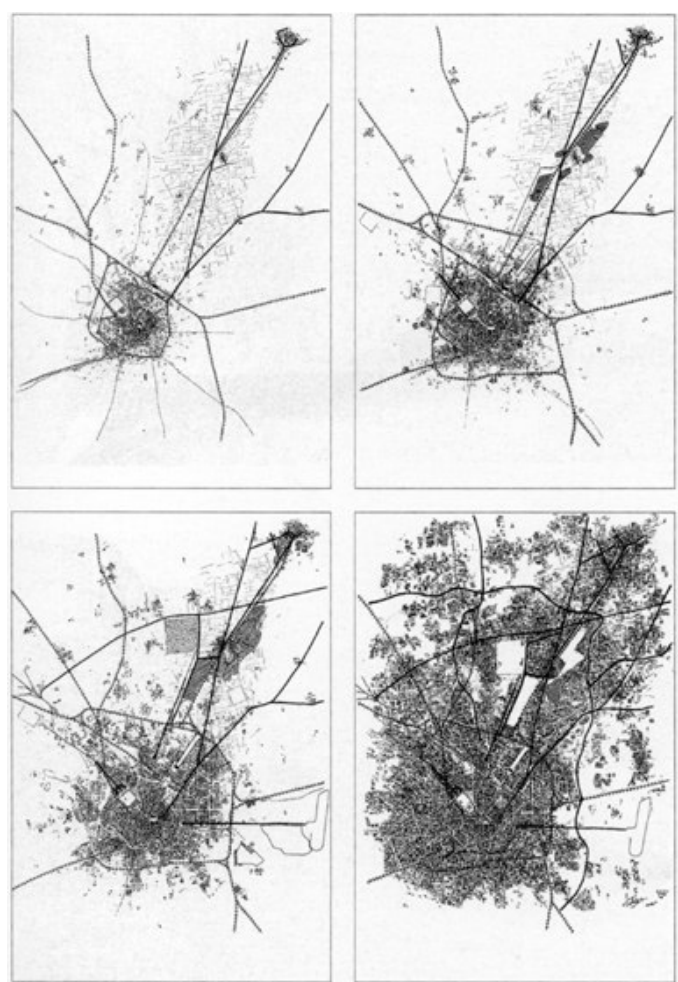

Fig. 51 - Quatro plantas de Milão e Monza e suas áreas edificadas, 1908, 1914, 1944, 1984. em Milão. Aborda uma complexidade de temas que compreendem a requalificação e recuperação de uma área da periferia historicamente consolidada pela estratificação de valores sociais, industriais e urbanos, com traçados históricos bem definidos e imagens formais consolidadas que pertencem ao contexto da periferia industrial.

A área da Bicocca é muito particular, faz parte de uma periferia 
localizada ao norte de Milão, a cerca de dez quilômetros do centro, onde foram implantadas as grandes indústrias pesadas do início do século passado. Ainda permanecem nela muitas indústrias pequenas e sua população é bastante densa.

O nome de Bicocca (casa abandonada) dado ao bairro, deriva da localização na área de uma casa de campo do século XVI que pertencia a uma família nobre milanesa, os Arcimboldi; hoje restaurado, o imóvel é sede de reuniões da direção da Pirelli. Com o tempo, o nome de Bicocca degli Arcimboldi foi simplificado para Bicocca.

As indústrias Pirelli já haviam se transferido, há alguns anos, para um subúrbio mais adequado, visto que a área onde funcionava a sede desde 1900, então zona rural, hoje faz parte do hinterland de Milão. Esse caso espelha a crise da cidade

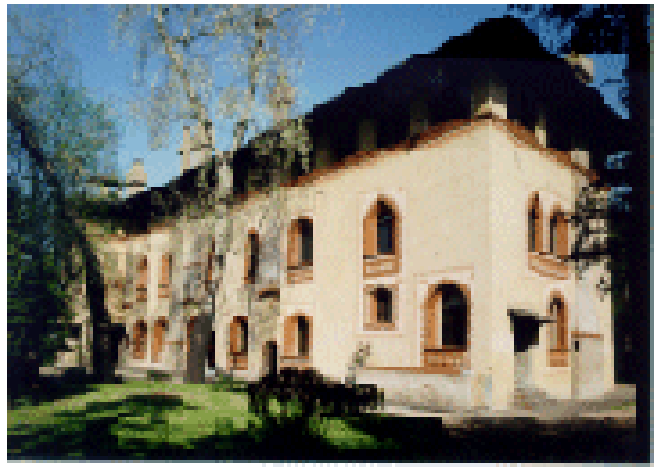

Fig. 52 - A "Bicocca degli Arcimboldi" sés. XVI

contemporânea e da perda de uma cultura do habitar em razão dos vazios deixados pelos complexos industriais que refletem também um problema comum em várias metrópoles.

Com uma superfície total de aproximadamente 680 mil metros quadrados de superfície e cerca de vinte novas edificações, o projeto foi totalmente realizado pelo arquiteto italiano Vittorio Gregotti, vencedor de um concurso fechado a alguns arquitetos, realizado em 1985. 


\section{O Concurso}

Organizado em duas fases pela própria Pirelli, o concurso contou com a participação, na primeira etapa, de dezenove arquitetos de renome internacional, entre os quais o brasileiro Joaquim Guedes. O objetivo seria ocupar os terrenos da Bicocca com um centro tecnológico polifuncional, agrupando laboratórios, centros de pesquisa e desenvolvimento, atividades industriais de tecnologia de ponta, centros de informática e telemática, institutos de formação profissional e universitária, e ainda espaços de encontros e serviços para atender às necessidades dos usuários.

A segunda fase teve a participação dos arquitetos Gino Valli, Roberto Gabetti, Aimaro Isola e Vittorio Gregotti. O projeto vencedor, de Gregotti, foi aprovado pela prefeitura somente em 1988, depois de muitas discussões e

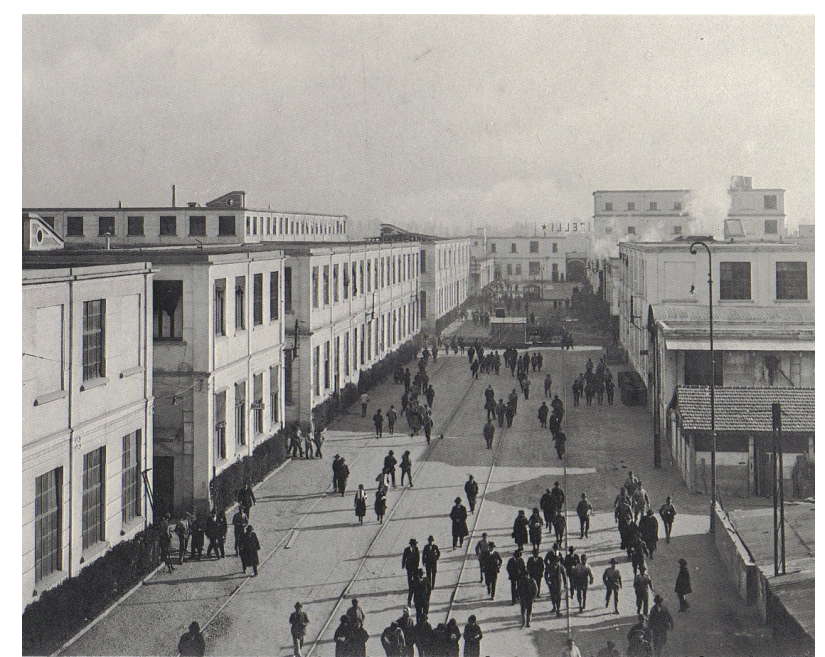

Fig. 53 - A avenida dos depósitos das Indústrias Pirelli - Bicocca, em 1922 mudanças de objetivos solicitadas pelos vários órgãos municipais.

A Pirelli e a prefeitura estipularam acordos econômicos básicos, com a colaboração entre iniciativa privada e pública, determinando quais edificações responderiam às necessidades da cidade. Para isso, utilizaram basicamente o critério de contrapartida e o pagamento de emolumentos à prefeitura para obter concessões de construção, por meio de lei aprovada em Milão, em 1977. Foi feito um macro-acordo entre grupos políticos para definir diretrizes estratégicas de desenvolvimento e de 
potencialização da cidade. O problema centrava-se sempre na avaliação de novos e possíveis usos do território.

$\mathrm{Na}$ Bicocca, questionou-se o aproveitamento desta específica área de localização estratégica, próxima à rodovia de ligação com o norte da Europa; as hipóteses variavam entre um imenso bairro residencial ou a fragmentação da área de maneira que ocorresse sua expansão natural.

\section{Conceitos do Projeto}

O projeto original sofreu grandes modificações; vários requisitos da prefeitura condicionaram sua aprovação. Um projeto de uma área tão relevante para a cidade como para todo o território deveria analisar a qualidade do espaço aberto e de uso público, fazer uma leitura da paisagem, do lugar, da sua atmosfera, de seu genius loci, das relações com o sitio. Deveria verificar, segundo Gregotti (1999), também, a articulação e diversificação das funções, mescla das atividades, dos serviços que definem a hierarquia dos espaços construídos e a presença de serviços de valor territorial que estabelecessem intercâmbios com outras partes da cidade, de forma individualizada.

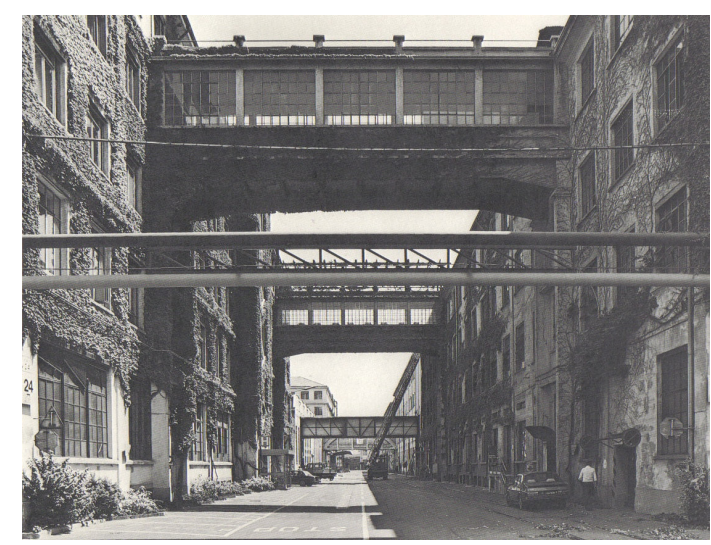

Fig. 55 - Uma passagem de interligação entre dois edifícios universitários na Bicocca, 2001.

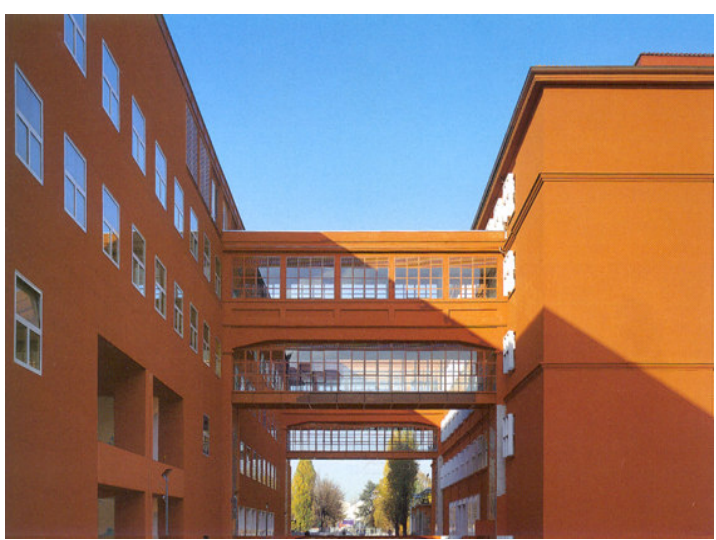

Fig. 54 - Uma passagem de interligação entre dois edifícios das Indústrias Pirelli - Bicocca, em 1947. 
O projeto resultante não procurou responder somente às ideologias de mercado; pretendia ser a simulação da reorganização ideal de uma sociedade reconstruída, sem pretensão de se tornar referência.

Questionou-se o novo desempenho dessa específica área e decidiu-se por concentrar nela aspectos muito especiais da periferia, como fixar em seu interior uma zona de uso misto e diferenciado por meio de residências e de serviços, especialmente de uso comunitário, ou seja, hospitais, escolas e universidades. Considerando, conforme Russo (1998, p. 111) afirma em Aree dismesse, que "a qualidade da operação urbana está na integração equilibrada entre funções diversificadas, [...] de maneira sejam criadas as condições de complexidade urbana".

Esses serviços exigem intercâmbios com outros setores da cidade, gerando possibilidades para suportar variações e complementação sem perda de identidade da população local, seja por tipo de atividade, poder econômico, origens ou idade.

Os recursos não se limitariam somente ao bairro circundante, mas se integrariam ao território, posicionando-o como pólo centralizador em relação ao norte da cidade, a fim de que o centro histórico de Milão não fosse o único ponto de referência da cidade.

"Na Itália, um centro histórico de periferia deve se

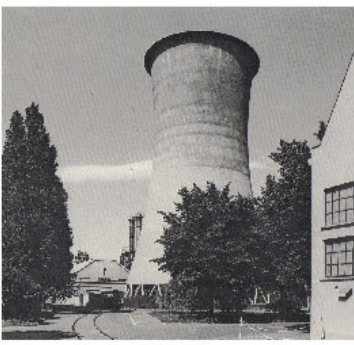

Fig. 57 - Torre de esfriamento, 1980.

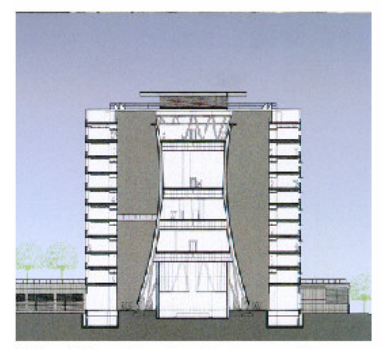

Fig. 58 - Corte da torre /Nova sede da Pirelli

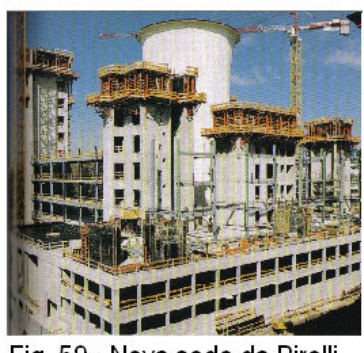

Fig. 59 - Nova sede da Pirelli em obras, 2003.

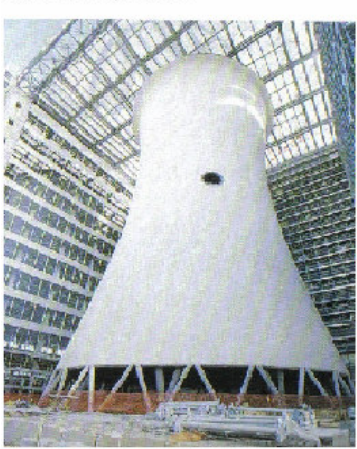

Fig. 60 - interior da Nova sede da Pirelli.

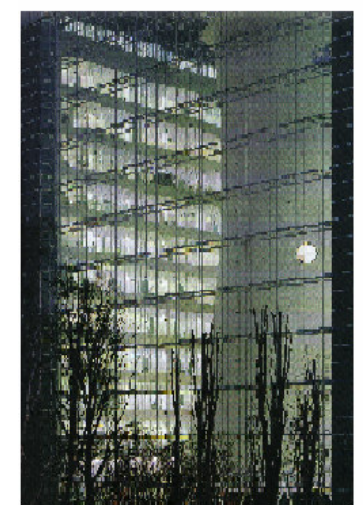

Fig. 61 -Nova sede da Pirelli. 
caracterizar por seis condições que representam uma precisa tomada de posição no debate sobre regulamentação e desregulamentação do desenho da expansão urbana". (I GREGOTTI, 1999, p. 30). Esses pontos que determinaram o desenho da Bicocca seguem abaixo na versão de Gregotti:

1 - Uma suficiente articulação dos diferentes usos e serviços e a presença de um serviço superior, de valor territorial, para promover intercâmbio com outras partes da cidade e da área;

2 - Uma população socialmente diferente - em seu próprio espaço interno - tanto por atividades, capacidade financeira, como mistura de origens, de idade e de condições;

3 - Cuidado no desenho e na gestão dos espaços abertos e coletivos: ruas, praças, espaços verdes, avenidas, etc. A relação entre os espaços construídos é tão importante quanto a qualidade da própria construção;

4 - Um sistema de transportes com acesso eficiente e variado sem acumular em seu interior um tráfego impróprio;

5 - Um desenho urbano ordenado por precisas regras de ocupação territorial, com uma leitura clara e, ao mesmo tempo, densa, para constituir um sistema rico e um conjunto de relações diferenciadas entre as partes;

6 - Uma estrutura em condições de organizar e fazer reconhecer partes ou espaços específicos e mistos, que estejam em condições de favorecer um sistema de orientação simples e em vários níveis de percepção (GREGOTTI, 1999, p.30 -32).

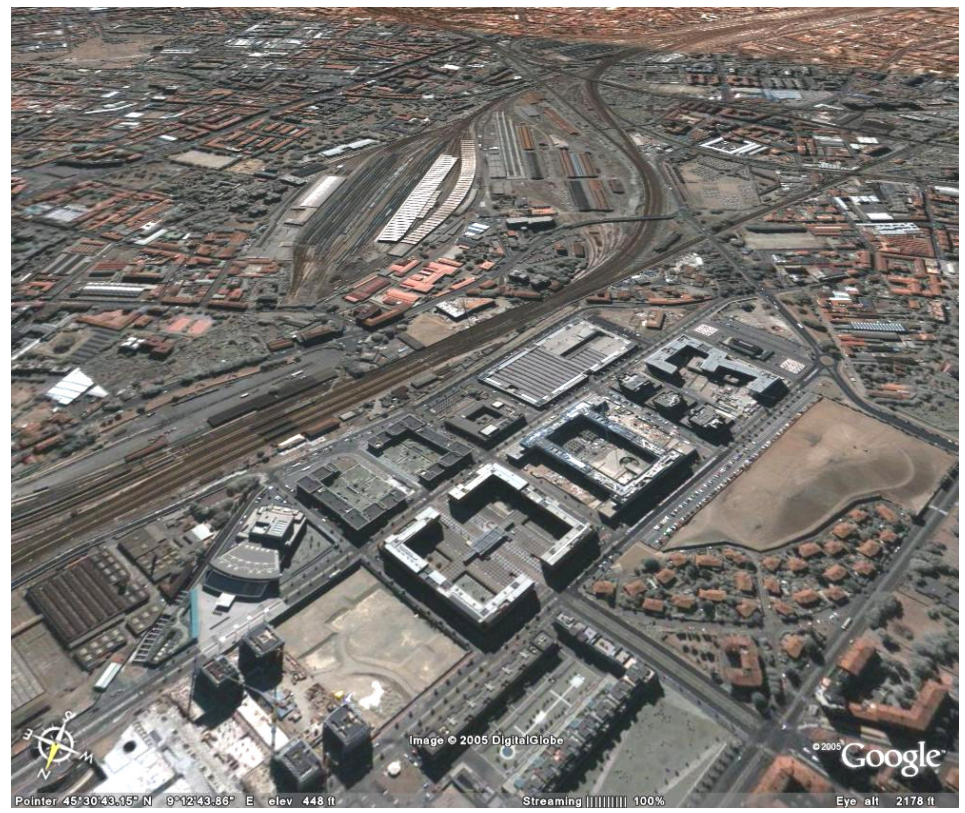

Fig. 56 - Uma vista aérea da Bicocca de hoje. 
O projeto, portanto, procurou conciliar a re-interpretação da multiplicidade e densidade da cidade histórica com as exigências do presente, ocupando o "vazio" com edifícios e espaços bem definidos (GREGOTTI, 2000). A Bicocca deveria se transformar em um "centro histórico" da periferia. Para isso, além da construção de edifícios residenciais destinados a várias classes sociais, e de comércio, foi construída a segunda Universidade de Milão; um grande teatro lírico, Degli Arcimboldi, que substituiria o teatro de ópera Alla Scala enquanto este estava sendo restaurado; um centro de pesquisa nacional, uma série de grandes bancos internacionais como a Deutsch Bank, pela excelente e estratégica localização. E espaços públicos, como uma seqüência de grandes praças, a fim de que essas obras adquirissem um valor dominante em todo o complexo.

Foi a ocasião de se poder, finalmente, oferecer, pelo menos em parte, uma direção ao desenvolvimento desordenado da cidade e suprir a falta de serviços adequados no plano metropolitano, urbano e mesmo de bairro. (GREGOTTI, 1999; RUSSO, 1998).

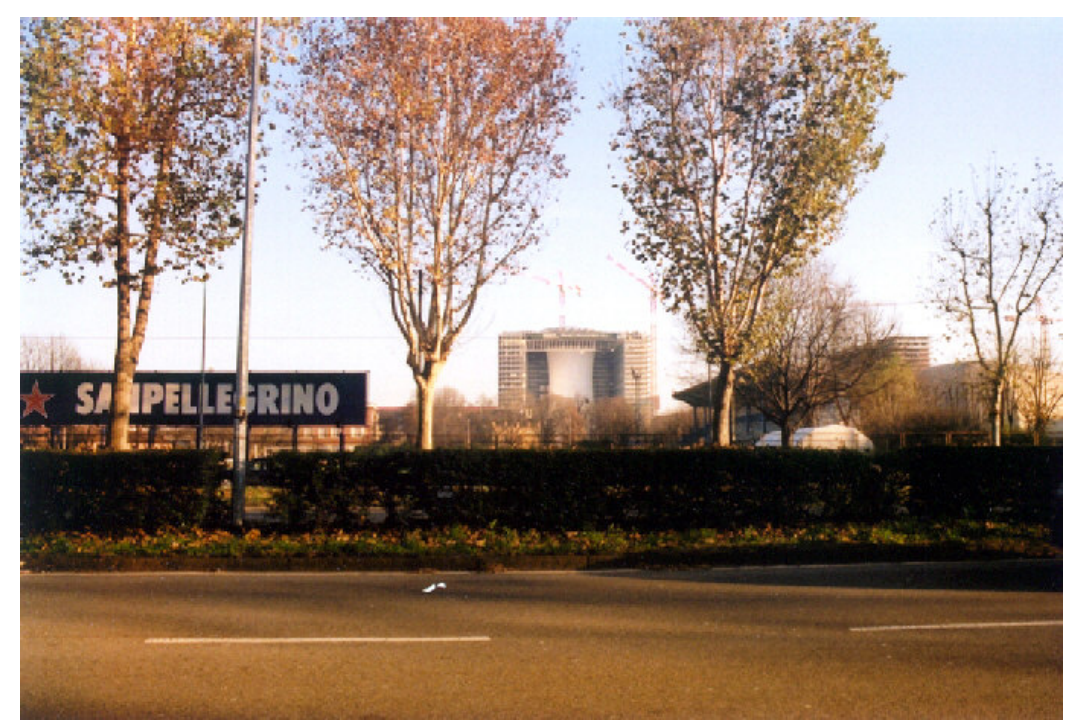

Fig. 62: Torre de esfriamento da Pirelli em obras de requalificação visto da avenida de acesso à cidade. 
A tipologia das construções da Bicocca inspira-se, mais do que na cidade histórica, nos elementos tradicionais da cidade operária do início do século; Gregotti quis dar a idéia da periferia milanesa com características de solidez do ponto de vista volumétrico, de simplicidade.

Fica claro que, em uma operação urbana dessa importância territorial, é necessário dar relevância não só aos objetos arquitetônicos, mas à relação entre eles, às seqüências, às escalas, ao espaço metavernacular.

A população prevista para a área é de 10 mil residentes, mais 40 mil composto de usuários ligados às atividades diurnas; para tanto, foi muito importante para essa movimentação de pessoas, a transformação do sistema de transportes urbanos milanês.

Em conclusão,

a arquitetura resultante não nasceu do nada, faz parte de uma história em transformação, da vontade de seguir novas atividades, novas funções e novas possibilidades de vida, embora ainda prevaleçam as tradições do início do século passado, quando a região começava a ser a mais produtiva de Milão. Isto não pode ser esquecido e nós o lembramos através da nossa arquitetura (GREGOTTI, 2000).

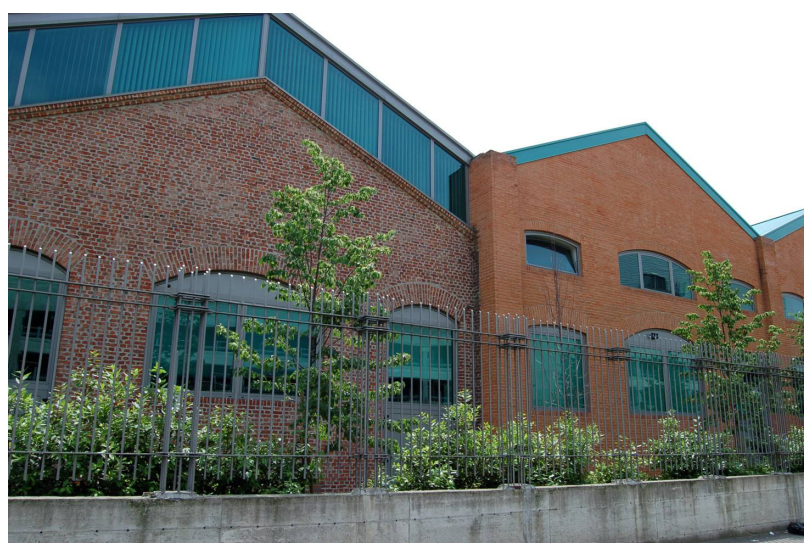

Fig. 63: Antigos hangares, hoje espaços usados para exposições em geral.
Este fato explica a tipologia das construções da Bicocca, inspirada mais nos elementos tradicionais da cidade operária daquele período, do que na cidade histórica.

Seguidor de um esquema mais rígido, de influência do norte europeu, onde a funcionalidade dos espaços internos é regra, Vittorio Gregotti constrói 
espaços de grande riqueza embora com um mínimo de diversificação de materiais, os detalhes foram cuidadosamente desenhados para serem reconhecidos nas diferentes escalas e para que não houvesse diferenças entre eles e o conjunto. Soluções contínuas - seja voltadas para o terciário, seja para o espaço público ou residencial - oferecem uma imagem convincente do complexo. O projeto mantém a mesma altura dos edifícios do restante da cidade, tanto os de caráter residencial como os de caráter terciário, caracterizados por meio do coroamento com soluções estéticas diferentes. Existe uma grande coerência entre o desenho urbano geral do complexo e as características arquitetônicas dos edifícios que o compõe, além de grande unidade na concepção do desenho dos edifícios.

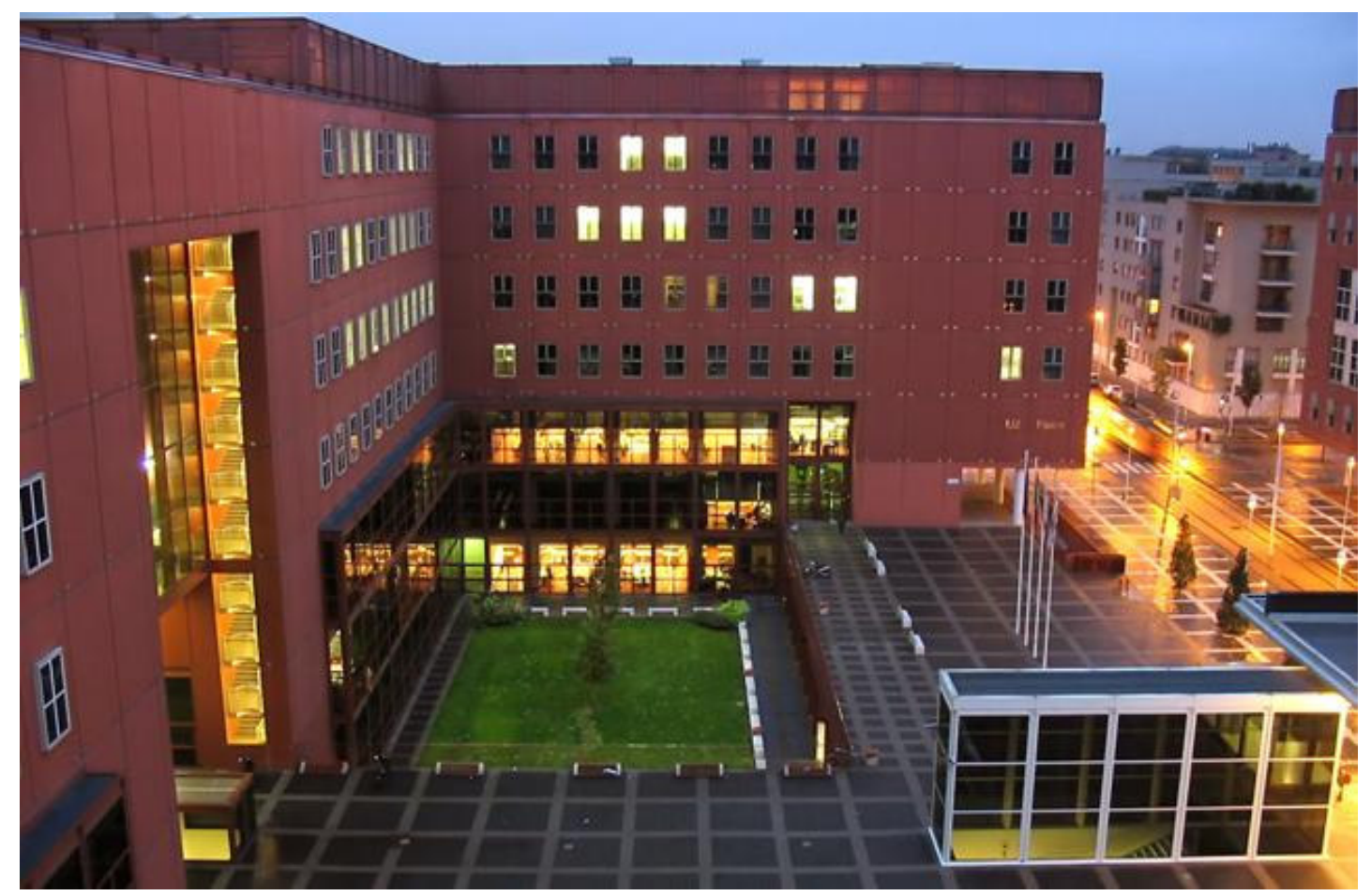

Fig. 64 - Bicocca, praça na proximidades da Universidade de geologia 
Simplicidade, ordem, organicismo e precisão, dão relevo ao resultado estético de Bicocca. O sistema viário foi perfeitamente resolvido e ampliado, complementando a trama preexistente que já se amalgamava com a cidade.

Ao desenho dos espaços abertos observou-se igual importância do desenho do espaço construído assim como suas relações. Os espaços verdes são bem maiores proporcionalmente do que aqueles do restante da cidade milanesa, mas foram tratados como elementos arquitetônicos diferentes.

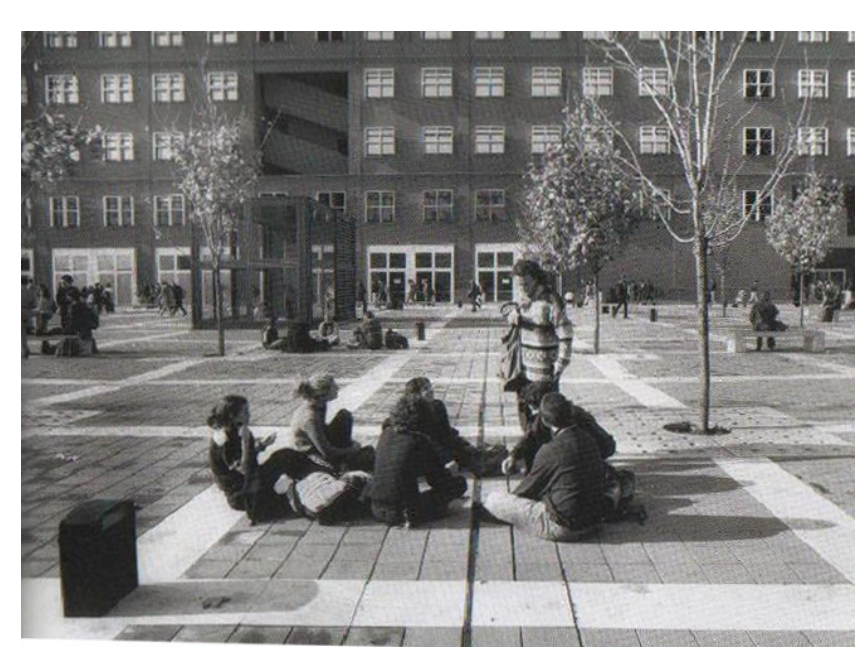

Fig. 65 - 66 - Praça na Universidade de Ciências, Bicocca, 2001.

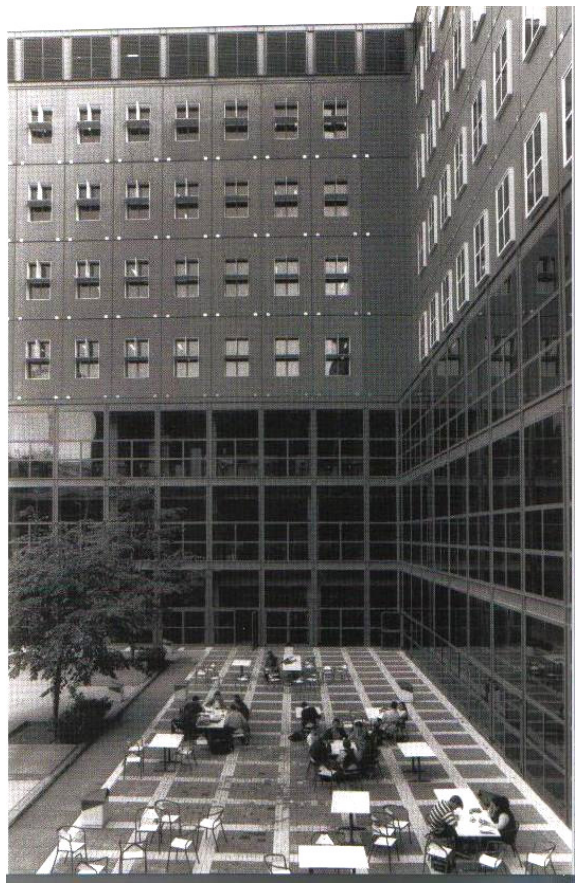

O sistema viário perfeitamente resolvido respeita a implantação da velha área industrial já conurbada à cidade. A trama original dava continuidade ao tecido urbano externo e, como tal, se ligava à cidade preexistente. Além disto, esta trama definia grandes quarteirões nos quais se colocou uma série de espaços públicos para pedestres - o espaço é todo público como uma seqüência de grandes praças - que adquire um valor dominante em todo o conjunto. 
Durante cinco anos após o concurso, tudo parou devido à transferência de alguns setores da Pirelli que funcionavam ainda na cidade e a problemas institucionais. Depois, o processo de construção se agilizou, mas foram necessários mais dez anos para a estrutura ser plenamente utilizada. Atualmente existe um sistema de metrô de superfície, permitindo que a Universidade funcione perfeitamente com mais de 20 mil alunos; o projeto hoje se estendeu para pequenas áreas limítrofes obsoletas.

A Pirelli resolveu permanecer no local, com suas fundações dos centro de pesquisa, sede administrativa e da diretoria internacional.

O projeto de Gregotti revela uma leitura pessoal da paisagem, do lugar, da sua atmosfera, das relações com o sítio. Não a paisagem como realidade vegetal ou pertencente a um ecossistema, mas como obra construída pelo homem para se destacar do seu entorno. O conceito de paisagem aqui transita entre o ato da leitura do visual e a percepção de seu entorno. Pois no entorno existe tudo: do vazio ao espaço construído, da praça à comunicação visual. Os códigos, para Gregotti, não são mais as relações entre a estrutura e a forma ou a fachada e a distribuição interna, e sim a interação destes aspectos entre si e entre os espaços da cidade. (GREGOTTI, 1999). Entretanto, não significa regionalismo. O projeto da Bicocca resgata tanto as demarcações dos terrenos industriais quanto as coberturas dos galpões, com leitura contemporânea da arquitetura em que os "ismos" são referências e não uma linguagem unívoca. 
SUPERFÍCIE DA ÁREA: $676.000 \mathrm{~m}^{2}$ ÁREA TOTAL CONSTRUÍDA: $628.366 \mathrm{~m}^{2}$ ÍNDICE DE USO DO TERRITÓRIO: 0,92 $\mathrm{m}^{2} / \mathrm{m}^{2}$ ESTACIONAMENTOS PÚBLICOS: $65.831 \mathrm{~m}^{2}$

Fig. 67 - Planta geral do projeto Bicocca de Gregotti e os tipos de uso.

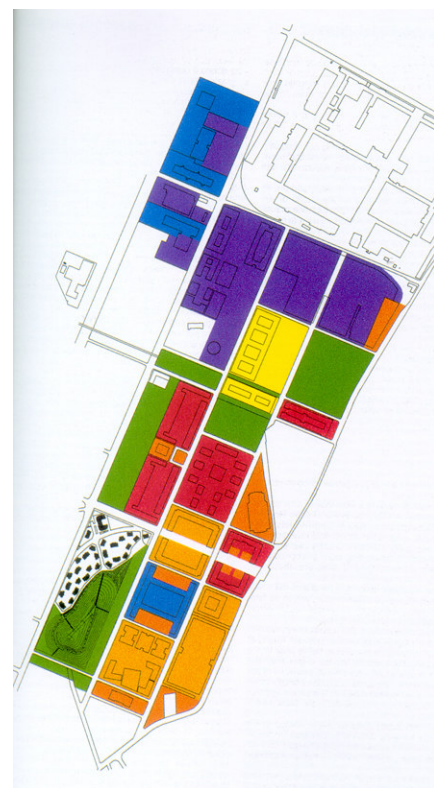

\begin{tabular}{|l|c|c|}
\hline EDIFÍCIOS PARTICULARES & & ÁREA CONSTRUÍDA em m² \\
\hline Pesquisa e produção & & 135.227 \\
\hline Residência & & 132.177 \\
\hline Atividades administrativas & & 130.538 \\
\hline Formação e pesquisa & & 114.200 \\
\hline Serviços para empresas & & 20.248 \\
\hline Parques e jardins & & 109.143 \\
\hline Serviços públicos e áreas públicas & & 49.590 \\
\hline \multicolumn{1}{|c|}{ Praças e percursos para pedestres } & & 46.000 \\
\hline \multicolumn{1}{|c|}{ Equipamentos esportivos } & & 77.500 \\
\hline Ruas e avenidas & & 98.000 \\
\hline
\end{tabular}

(GREGOTTI, 2001, p.67). 


\section{Conclusão}

Na cidade histórica, a morfologia urbana tem a função de assegurar a permanência, a unidade e a continuidade no espaço e no tempo, enquanto a arquitetura é submetida a uma transformação continua que the impõe, por definição, ser heterogênea, descontinua e fragmentária (HUET, 1984).

Hoje, as cidades são formadas por arquiteturas que se tornaram monumentos isolados, em razão de o espaço não ser mais estruturado em um tecido urbano composto por ruas, praças, cheios e vazios, o que acabou alterando a relação indivíduo-espaço. O modo mais corrente de dar vida a um pedaço da cidade no cotidiano contemporâneo é o rito do consumismo, já que através dessa compulsão passa-se a imagem não do que o indivíduo é, mas do que pode vir a ser ao comprar e ostentar determinados bens de consumo.

Na metrópole contemporânea não se oferece mais a ágora ao cidadão, a espacialidade física de lugares públicos que incentivam encontros, trocas e relações sociais; não mais arquiteturas que desenvolvem o bem-estar no dia-adia, mas muitos não-lugares, sem conotações mais consistentes.

Em uma análise da qualidade de vida cotidiana que considere a destruição do espaço urbano pela desvalorização da rua e dos espaços livres públicos, portanto, da memória e da própria história urbana, constata-se que as referências comuns desaparecem, os lugares se tornaram não-lugares, uma vez que é no não-lugar que não existe espaço para a memória, para a história e para a percepção sensorial. O não-lugar pode ser qualquer lugar que não 
mantenha ligações com o genius loci do território que o circunda; é aquele onde o indivíduo inexiste ao se diluir na massa de passantes e consumidores, cada qual procurando somente satisfazer suas próprias exigências. Conforme assevera Marc Augé, é no anonimato dos não-lugares, das paisagens contemporâneas esvaziadas de sentido e de história, que se vivencia hoje, solitariamente, a comunhão dos destinos humanos. As exigências mudaram, mas alerta o arquiteto espanhol Oriol Bohigas (1994), "é prioridade organizar os espaços públicos para controlar a cidade". É o que está além do espaço privado que constitui a cidade; ao renovar ou reutilizar o espaço público, provoca-se uma evolução e recuperação do espaço privado.

Dessa maneira, a conservação como prática específica para salvaguardar e tutelar os valores históricos e garantir sua continuidade deve ampliar seus próprios significados e potencialidades, integrando-se ao complexo processo de transformação urbana, às suas múltiplas formas de vida contemporânea e às relativas modificações.

Construir no construído - aproveitando principalmente as áreas de obsolescência que fazem parte dos tecidos e traçados existentes - aliada à conseqüente melhoria da cidade consolidada, valorizando as preexistências e os traçados históricos e geográficos, são idéias estratégicas para a rearticulação da organização urbana e de seus espaços públicos. A recuperação das áreas de obsolescência caminha paralelamente a um processo de investimento voltado à modernização do sistema urbano.

Essa questão pode parecer de importância menor para uma grande metrópole, em razão das inúmeras problemáticas que deve enfrentar comparativamente a uma cidade de tamanho médio. No entanto, é preciso 
avaliar quão relevante significa ordenar pelo menos parte do tecido metropolitano para evitar sua dissolução em um território sem limites, e, ao mesmo tempo, identificar e poupar os elementos emblemáticos e as relações que estabelecem entre si, suas conseqüências, escalas e hierarquias.

Cada cidade tem sua história, sua evolução, seu próprio desenvolvimento, sua problemática e soluções que podem ser generalizadas. Mas, por maior que sejam os desafios que a cidade tenha que enfrentar, a cultura de uma comunidade, entendida em seu aspecto mais amplo de ser, de viver, de confrontar-se, nasce da consolidação e conscientização de experiências e valores que os indivíduos da própria comunidade acatam. A lembrança e a memória são elementos fundamentais para a formação de uma cultura. Não se pode esquecer que memória nada mais é do que um depositário das experiências coletivas que se transmitem e se tornam cultura; a memória tem a faculdade de conservação do saber fazer, da consciência de si próprio, da lembrança de valores coletivos e de semente para 0 desenvolvimento da personalidade. Ela é criadora da identidade das cidades, dos países, de seus ritos, das celebrações e festas que acontecem nas ruas, nas praças, nas próprias calçadas que acabam definindo o espaço urbano construído , estabelecendo forte relação entre arquitetura e a cidade.

A cidade hoje deve poder ser lida, reinterpretada e re-proposta de maneira sempre atualizada, dispor de seus recursos, entre a arquitetura vernacular e o espaço metavernacular. Um percurso que se articula por meio de contínuas explorações no contexto das dinâmicas urbanas, à procura de uma possível hierarquia de valores que concentram o valor da urbs e da civitas 
ou, dito de outra maneira, uma trajetória que aponta para a relação entre a memória e os signos, a cidade e a sociedade.

É necessário que os habitantes conheçam o próprio patrimônio vernacular e fazer entender o quanto esse valor se reflete na própria identidade. De maneira diferente das artes decorativas e da arquitetura monumental, a arquitetura vernacular nunca seguiu caprichos e modismos. Ao contrário, evoluiu no tempo de maneira quase imperceptível, adaptando-se às dimensões e às necessidades humanas sem maneirismos. Através dela podese estudar tipos e tipologias esquecidos, delinear um processo de exploração, de conhecimento e crítica de uma realidade cujo sentido mais profundo parece submerso e complexo. 


\section{Bibliografia}

ANDERSON, Stanford. Calles: problemas de estructura y diseño. Barcelona: Editorial Gustavo Gili, 1981.

ARGAN, Giulio Carlo. História da Arte como História da Cidade. Martins Fontes: São Paulo, 1993.

. Projeto e Destino. Martins Fontes: São Paulo, 2000.

ARRUDA, Maria Arminda Nascimento do. Tempos, Lugares, Sociabilidade. Metrópole e Cultura: São Paulo no meio século XX. Bauru: Edusc, 2001.

AUGÉ, Marc. Non luoghi: introduzione ad un'antropologia della sumodernità. Milano: A coop. Sez. Elèuthera, 1993.

AYMONINO, Carlo. Il significato delle città. Venezia: Marsilio, 2000.

BASTOS, Maria Alice Junqueira. Pós-Brasília: rumos da Arquitetura Brasileira. São Paulo: Perspectiva, 2003.

BELSKI, Maria Pia; MONTRUCCOLI, Simona. Milano: da posta per cavalli a città regione. Barzago: Casa Editrice Marna, 2002.

BENEVOLO, Leonardo. La cattura dell'infinito. Roma: Laterza, 1991. . La città nella storia d'Europa. Roma/Bari: Laterza, 1993.

BOHIGAS, Oriol; FILLION, Odille. La ville: six interview d'architects. Paris: Le Moniteur, 1994.

BRUAND, Yves. L'architecture contemporaine au Brésil. Tome I e II. Lille: Service de reproduction des thèses, 1973. 
CACHE, Bernard; SPEAKS, Michael. Earth Moves: the furnishing of territiories. Massachusetts: MIT Press, 1995

COMAS, Carlos Eduardo Dias. O Espaço da Arbitrariedade. Revista Projeto, $\mathrm{n}^{\circ}$ 91, São Paulo: Projeto, set. 1986.

COSTA, Lucio. Lucio Costa: registro de uma vivência. São Paulo: Empresa das Artes, 1995.

. Lucio Costa: sobre arquitetura. Porto Alegre: Centro dos Estudantes universitários de arquitetura, 1962.

DAL CO, Francesco; MAZZARIOL, Giuseppe (orgs.). Carlo Scarpa opera completa. Milano: Electa, 1984.

DURHAN, Eunice R. A Caminho da Cidade. São Paulo: Perspectiva, São Paulo, 1973.

FRAMPTON, Kenneth. Historia Critica de la Arquitectura Moderna. Barcelona: Gustavo Gili, 1981

FRANCASTEL, P. Lo spazio figurativo dal Rinascimento al Cubismo. Torino: Einaudi, 1957.

FREMONT, Armand. La Regione: uno spazio per vivere. Milano: Franco Angeli Editori, 1983.

GAMBI, Lucio; GOZZOLI, Maria Cristina. Le città nella storia d'Italia: Milano. Roma-Bari: Laterza, 1997.

GOULART REIS FILHO, Nestor. Quadro da Arquitetura no Brasil. São Paulo: Perspectiva, São Paulo, 1976. 
SALMONI, Anita; DE BENEDETTI, Emma. Arquitetura Italiana em São Paulo. São Paulo: Perspectiva, 1981.

GREGOTTI, Vittorio. I/ territorio dell'architettura. Milano: Feltrinelli Economica, 1977.

. Ponto Estratégico. Revista $A U$, o 91, ago./ set. 2000, p 37-39. Entrevista concedida a Marisa Barda.

GREGOTTI, Vittorio et al. IL PROGETTO Bicocca 1985-1998. Milano: Skira, 1999.

GUIMARAES, Laís de Barros Monteiro. História dos Bairros de São Paulo: Liberdade. São Paulo: Prefeitura do Município de São Paulo, Secretaria Municipal de Cultura, 1979.

HALL, E. T. La Dimensione nascosta. Milano: Bompiani, 1968.

HARVEY, David. Condição Pós-Moderna: uma pesquisa sobre as origens da mudança cultural. São Paulo: Loyola, 1992.

HEERS, Jacques. La città nel medioevo: Paesaggi, Poteri e conflitti. Milano: Jaca Book, 1995.

HERTZBERGER, Herman. Lições de Arquitetura. São Paulo: Martins Fontes, 1996.

HILLMAN, James. Encarando os Deuses. São Paulo: Cultrix/ Pensamento, 1980.

HUET, Bernard. La città come spazio abitabile. Lotus International. Milano: Electa, 1984. 
JACOBS, Jane. Vita e Morti delle grandi città: saggio sulle metropoli americane. Torino: Edizioni di Comunità, 2000. (trad. bras. Morte e Vida de Grandes Cidades. 2ed. São Paulo: Martins Fontes, 2001).

JAMMER, M. Storia del concetto di spazio. Milano: Feltrinelli, 1966.

JENCKS, C.; BAIRD, G. El Significado en Arquitectura. Madrid: H. Blume Ediciones, 1975.

JEUDY, Henri Pierre. La machinerie patrimoniale. Paris: Sens \& Tonka, 2001.

. Espelho das Cidades na Folha de São Paulo. Disponível em $<\mathrm{http}: / /$ www.casadapalavra.com.br/noticias.asp?idNews=113>, acesso em 10 jun. 2006, entrevista a Amarilis Lage.

KHAN, Luis. Credo. Architectural Design, n.5, 1974.

KRIER, Leon. Carta Per La Ricostruzione Della Città Europea. Disponível em: $<\mathrm{http}: / /$ www.stefanoborselli.elios.net/scritti/krier_carta.htm>. Acesso em: 26 dez. 2006.

KOOLHAAS, Rem. Delirous New York. Milano: Electa, 2004.

. Bigness, ovvero il problema della Grande Dimensione. In: Domus, Milano: Editoriale Domus, $n^{\circ} 764$, out. 1994, p. 87.

KÜHL, Beatriz Mugayar. Arquitetura do Ferro e Arquitetura Ferroviária em São Paulo: reflexões sobre a sua preservação. São Paulo: Ateliê, 1998.

LANGENBUCH, Jurgen Richard. A Estruturação da Grande São Paulo. Rio de Janeiro: Fundação IBGE, Depto de Documentação e Divulgação Geográfica e Cartográfica, 1971.

LA BICOCCA abitata. Milano: Skira, 2001. 
LEIBNIZ, G.W. Saggi Filosofici e Lettere. Bari: Laterza, 1963.

LEMOS, Carlos A. C. Casa Paulista: História das moradias anteriores ao ecletismo trazido pelo café. São Paulo: Edusp, 1999.

LÓPEZ DE LUCIO, Ramon. El espacio publico en la ciudad europea: entre la crisis y lãs iniciativas de recuperación: implicaciones para Latinoamerica. Revista do Ocidente, Barcelona, n. 230-231, 2000.

MARX, Karl. O 18 do Brumário de Luís Bonaparte. Coimbra: Nosso Tempo, 1971.

MONEO, Rafael. La solitudine degli edifici e altri scritti: sugli architetti e altri scritti. Torino: Editora Umberto Allemandi \& C., 2004.

MANZELLE, Maura. Carlo Scarpa: L'opera e la sua conservazione I.1998/ III. 2000. Milano: Skira, 2002.

MORANDI, Corinna. Milano la grande trasformazione urbana. Venezia: Marsílio editori, 2005.

MOREIRA, Clarissa da Costa. A Cidade Contemporânea entre Tabula Rasa e Preservação. São Paulo: Unesp, 2004.

MORSE, Richard M. Formação Histórica de São Paulo. São Paulo: Difusão Européia, 1970.

PIERLUIGI, Nicolin. Introduzione. In: TRIENNALE DI MILANO. Le città immaginate: un viaggio in Italia, nove progetti per nove città. Electa: Milano, 1987.

NIETZSCHE, Friedrich Wilhelm. Nietzsche: obras incompletas. São Paulo: Abril Cultural, 1978, (Os Pensadores). 
NORBERG-SCHULZ, Christian. Genius Loci: paesaggio ambiente architettura. Milano: Electa, 2003.

PIGNATELLI, Paola Coppola. Spazio e Immaginario: maschile e femminile in architettura. Roma: Officina Edizioni, 1982.

PORTOGHESI, Paolo. Dopo l'architettura moderna. Bari: Laterza, 1982. . Leggere l'architettura. Roma: Newton Compton editori, 1981

QUARONI, Ludovico. La Città Fisica. Roma/ Bari: Laterza, 1981.

REIS FILHO, Nestor Goulart. Quadro da Arquitetura no Brasil. São Paulo: Perspectiva, 1987.

ROGERS, Ernesto N. Esperienza dell'archiettura. Milano: Einaudi, 1958. . Editorial. Casabella Continuità, nº 199, dez. 1953.

ROGERS, E. N.; TYRWHITT, J.; SERT, J.L. I/ cuore della città. Milano: Hoepli, 1952.

RONCl, Fabio. Giullari: il tempo e lo spazio scenico nel medioevo. Disponível em

$<$ http://www.medioevo.com/index.php?option=com_medioevocontent\&task=vie w\&id=163\&ltemid=34\&limit=1\&limitstart=4\&lang=it $>$ acesso em 05 jul. 2006. ROSSI, Aldo. L'architettura della città. Milano: Clup, 1978.

. Tre città: Perugina, Milano, Mantova. Milano: Electa, 1984, (Quaderni di Lotus).

RUSSO, Michelangelo. Aree dismesse: forma e risorse della "città esistente". Napoli: Edizioni Scientifiche Italiane, 1998. 
SAGGIO, A. La via dei simboli. Disponível em <http://architettura.supereva.com/coffeebreak/20001215/>, acesso em 12 mar. 2006.

SALGADO, Ivone. Pierre Patte e a Cultura Urbanística no lluminismo Francês. Cadernos de Pesquisa do LAP: Revista de Estudos sobre Urbanismo, Arquitetura e Preservação. São Paulo, v. 38, 2003.

SALMONI, Anita; DEBENEDETTI, Emma. Arquitetura Italiana em São Paulo. São Paulo: Perspectiva, 1981.

SECCHI, Bernardo. Prima Lezione di urbanismo. Milano: Laterza, 2000 (trad. bras. Primeira Lição de Urbanismo. Tradução de Marisa Barda e Pedro MR. Sales. São Paulo: Perspectiva, 2006). . La città del ventesimo secolo. Milano: Laterza, 2005.

SENNET, Richard. O Declínio do Homem Público: as tiranias da intimidade. São Paulo: Companhia das Letras, 1995.

SITTE; Camillo. L'arte di costruire le città: l'urbanistica secondo i suoi fondamenti artistici. Milano: Jaca Book, 1981.

TAFURI, Manfredo. Teoria e História da Arquitectura. Lisboa/ São Paulo: Editorial Presença/ Martins Fontes, 1979.

TAFURI, Manfredo; DAL CO, Francesco. Architettura contemporanea. Milano: Electa, 1976.

TRIENNALE DI MILANO. Le città de mondo e il futuro delle metropoli: oltre la città, la metropoli. Milano: Editrice Electa, 1988. 
. Il Centro Altrove, Periferie e nuove centralità nelle aree metropolitane.

Milano: Electa, 1995.

TOLEDO, Benedito Lima de. Prestes Maia e as Origens do Urbanismo Moderno em São Paulo. São Paulo: Empresa das Artes Projetos e Edições Artísticas, 1976.

. Três Cidades em um Século. São Paulo: Livraria Duas Cidades, 1981.

VAGAGGINI, V (coord.). Spazio geografico e spazio sociale. Milano: Franco Angeli Editori, 1980.

VENTURI, Robert. Complessità e contradizioni nell'architettura. Bari: Dedalo Libri, 1980.

VILLAÇA, Flavio. Espaço Intra-Urbano no Brasil. São Paulo: Livros Studio Nobel, 1998.

WILHEIM, Jorge. São Paulo Metrópole 65. São Paulo: Difusão Européia do Livro, 1965.

\section{Portais da Web:}

www.comune.milano.it

www.gallaratese.it/

www.dti.unimi.it/ samarati/lmages/Crema.jpg

www.superstudiogroup.com/map.php

www. Wolton.cnrs.fr/ glossaire

http://architettura.supereva.com/ 
www.medioevo.com

http://www.stefanoborselli.elios.net/

www.chem.polimi.it/formazione/beniculturali/BIBLIOGRAFIA\%20PROF.\%20BE LLINI/REST-POL.pdf

http://architettura.supereva.com/coffeebreak/20001215/

http://www.casadapalavra.com.br/noticias.asp?idNews=113

http://www.storiaurbana.it/biblioteca/studi/Zucconi.brasile.rtf 


\section{ILUSTRAÇÕES:}

Fig. 1 - Sobreposição mapa Milão século 1980/ Muralhas romanas

FONTE: GAMBI, Lucio; GOZZOLI, Maria Cristina. La città nella storia d'Italia: Milano. Roma: Laterza, 1982, p.41.

Fig. 2 - Piazza Del Duomo di Milano

FONTE: <www.discountmilano.com/tour/Classico/PzaDuomo418x296.jpg>, acesso em 15 nov. 2006.

Fig. 3 - Piazza di Siena

FONTE:<http://www.benessereviaggi.it/alberghi.asp/a_siena-terme/hotelssiena-terme.html>, acesso em 15 nov. 2006.

Fig. 4 - Diferentes disposições de objetos em um terreno FONTE: CIANCARELLI, Luca. Tipo e complessità architettonica: trasformabilità e scomponibilità tipologica. Roma: Kappa, 2005, p. 2.

Fig. 5 - Divisões do quadrado, do paralelograma e suas combinações com 0 círculo.

FONTE: CIANCARELLI, Luca. Tipo e complessità architettonica: trasformabilità e scomponibilità tipologica. Roma: Kappa, 2005, p. 3.

Fig. 6 - Campo rural

FONTE: <www.confagricoltura.org/imgnews/campi2.jpg>, acesso em 15 nov. 2006.

Fig. 7 - Galeria Vittorio Emanuele, em Milão, Itália

FONTE: <www.egm.it/comuni/milanogalleria.jpg>, 15 nov. 2006.

Fig. 8 - Uma rua de Milão

FOTO: Marisa Barda

Fig. 9 - Variações da estrutura urbana na praça do Duomo em Milão de 1730 a 1960

FONTE: AYMONINO, Carlo. I/ significato delle città. Venezia: Marsilio Editore, 2000, p. 29.

Fig. 10 - Casa da Cascata F.L. Wright

FONTE: <www.gibson-design.com/images/sketch-kaufmann2.jpg>, acesso em 11 abr. 2006

Fig. 11 - Proposta de Le Corbusier para a Universidade do Brasil, no Rio de 
Janeiro

FONTE: <http://www.arcoweb.com.br/debate/debate64.asp>, acesso em 15 nov. 2006.

Fig. 12 - Léon Krier: carta para reconstrução da cidade européia

FONTE: <http://www.stefanoborselli.elios.net/scritti/krier_carta.htm>, acesso em 15 nov. 2006.

Fig. 13 - Desenho de um Shopping Center

FONTE: <http://faculty.washington.edu/jbs/itrans/kasp4.gif>, acesso em 15 nov. 2006.

Fig. 14 - A soleira da porta

FONTE: <www.dj-design.com/Paintings/Old_Woman.JPG>, acesso em 15 nov. 2006.

Fig. 15 - Espaço Público/ semi-privado de um edifício da rua Maranhão, São Paulo

FOTO: Marisa Barda.

Fig.16 - Espaço Intermediário, pórticos na Itália.

FONTE: < http://www.diegobridi.it/ultimidipinti.htm> acesso em 04 jan. 2007.

Fig. 17 - Um não-lugar: Cebolão da Marginal Pinheiros /Marginal Tietê - SP FOTO: Pulsar Imagens foto Delfim Martins.

Fig. 18 - Brasília.

FONTE: SANOVICZ, Abrão V.; KATINSKI, Julio R. Acrópole: Brasília. São Paulo: Editora Max Gruenwald, 256, 257, 1960, p. 42.

Fig. 19 - Trulli: casas tradicionais de Alberobello, Bari, Itália.

FONTE: <http://home.worldcom.ch/ negenter/458aSemperlntro.html> acesso em 15 nov. 2006.

Fig. 20 - Sobrados em Perdizes, São Paulo

FOTO: Pulsar Imagens, foto Delfim Martins)

Fig. 21 - Concerto em uma praça em Perugia, Itália

Fig. 22 - Pórticos em Imola, Itália

FONTE: <http://temi.comune.imola.bo.it/riqualifica/portici/progetto.htm>, acesso em 15 nov. 2006.

Fig. 23 - Unité d'Habitation de Marseille (Le Corbusier)

Fig. 24 - Terminal de ônibus Dom Pedro II - SP 
FOTO: Pulsar Imagens, foto Delfim Martins

Fig. 25 - Favela Marginal Tietê /Ponte de J. Mesquita Neto - SP

FOTO: Pulsar Imagens, foto Delfim Martins.

Fig. 26 - Edifício São Vito - São Paulo.

FONTE: <www.benettontalk.com/sao.paulo.link.jpg>, acesso em 15 nov. 2006.

Fig. 27 - Marginal Tietê /Ponte do Pacaembú - São Paulo

FOTO: Pulsarlmagens, foto Delfim Martins.

Fig. 28 - Vista aérea do Duomo e do centro de Milão, 2006.

FONTE: <http://web.tiscali.it/kribo/Varie/milano/milano.htm>, acesso em $17 \mathrm{dez}$. 2006.

Fig. 29 - Desenho de Leonardo da Vinci, 1497 com estudo de canais para Milão.

FONTE: GAMBI, Lucio; GOZZOLI, Maria Cristina. La città nella storia d'Italia: Milano. Roma: Laterza, 1982, p. 45.

Fig. 30 - Quatro seqüências das dilatações urbanas: 1800, 1860, 1900, 1940. Desenho Giuseppe De Finetti em 1969.

FONTE: GAMBI, Lucio; GOZZOLI, Maria Cristina. La città nella storia d'Italia: Milano. Roma: Laterza, 1982, p. 320

Fig. 31 - Expansão urbana de São Paulo 1905, 1930, 1954, 1985. FONTE: <www.unesco.org.uy/phi/libros/radar/art25.html>, acesso em 18 abr. de 2006.

Fig. 32 - Esquema da cidade de Milão dividida por zonas, 2000.

FONTE: <www.comune.milano.it>, acesso em 17 set. 2005.

Fig. 33 - Arquivo Giuseppe Terragni - Casa Rustici, Milão, 1935-1937 FONTE. <http://www.consarc-ch.com/URLnuovo/galle/musi/musrus.jpg>, acesso em 6 nov. de 2006.

Fig. 34 - Expansão urbana de São Paulo desde 1905.

FONTE: <http://www.unesco.org.uy/phi/libros/radar/art25.html>, acesso em 15 nov. 2006.

Fig. 35 - Torre Velasca - projeto BBPR 1957/59

FONTE: <www.olivari.it/designers/bbpr.html>, acesso em 17 dez. 2006.

Fig. 36 - Milão, com localização da via Bramante, 2002

FONTE:Tutto città Milano 2004, Milano: editore Seat, 2004, p. 5. 
Fig. 37 - Edifício da via Bramante pouco antes das obras de recuperação.

FOTO: Marisa Barda.

Fig. 38 - Edifício da via Bramante após as obras de recuperação.

FOTO: Marisa Barda.

Fig. 39 - Edifício da via Bramante Planta andar térreo.

FONTE: Arquivo Marisa Barda.

Fig. 40 - Edifício da via Bramante Planta primeiro andar.

FONTE: Arquivo Marisa Barda.

Fig. 41 - Edifício da via Bramante Planta segundo andar.

FONTE: Arquivo Marisa Barda.

Fig. 42 - Edifício da via Bramante Planta terceiro andar.

FONTE: Arquivo Marisa Barda.

Fig. 43 - Ed. via Bramante pouco antes das obras de recuperação, $3^{\circ}$ andar. FOTO: Marisa Barda.

Fig. 44 - Ed. via Bramante após as obras de recuperação, local para lavagem de roupa.

FOTO: Matteo Piazza.

Fig. 45 - Ed. via Bramante pouco antes das obras de recuperação.

FOTO: Marisa Barda.

Fig. 46 - Ed. via Bramante após as obras de recuperação.

FOTO: Matteo Piazza

Fig. 47 - Edifício habitação popular Gallaratese (1967-1972) projeto arq. Aldo Rossi.

FONTE: Rossi, Aldo. Buildings and Projects. New York: Rizzzoli, 1985. p. 80.

Fig. 48 - Foto de edifício de habitação popular na área da Bicocca. Projeto arquivo Vittorio Gregotti, 1999.

FOTO: Marisa Barda.

Fig. 49 - Vista do edifício de via Bramante após as obras de recuperação.

FOTO: Matteo Piazza.

Fig. 50 - Foto área da área Bicocca antes das obras, 1984.

FONTE: Progetto Bicocca: invito alla progettazione urbanística e architettonica di un centro tecnologico integrato. Milano: Pirelli, 1984, p. 8-9.

Fig. 51 - Quatro plantas de Milão e Monza e suas áreas edificadas, 1908, 1914, 1944, 1984. 
FONTE: I quaderni della Bicocca 01: 1985-1998. Milano: Skira, 1998, p.10.

Fig. 52 - A "Bicocca degli Arcimboldi" século XVI.

FONTE: <http://www.turismo.comune. $\mathrm{milano} . \mathrm{it} / \mathrm{pls} / \mathrm{milano} / \mathrm{turismo}$ ?pid=21501>, acesso em 16 nov. 2006.

Fig. 53 - A avenida dos depósitos das Indústrias Pirelli - Bicocca, em 1922.

FONTE: Progetto Bicocca: invito alla progettazione urbanística e architettonica di un centro tecnologico integrato. Milano: Pirelli, 1984, p. 17.

Fig. 54 - Uma passagem de interligação entre dois edifícios das Indústrias

Pirelli - Bicocca, em 1947

FONTE: Progetto Bicocca: invito alla progettazione urbanística e architettonica di un centro tecnologico integrato. Milano: Pirelli, 1984, p. 22.

Fig. 55 - Uma passagem de interligação entre dois edifícios universitários na Bicocca, 2001.

FONTE: I quaderni della Bicocca 01: 1985- 1998. Milano: Skira, 1998, p. 74.

Fig. 56 - Uma vista aérea da Bicocca de hoje.

FONTE: <http://www.mater.unimib.it/Segreteria_Didattica/Images/Bicoccasat1.jpg>, acesso em 16 nov. 2006

Fig. 57 - Torre de esfriamento da Pirelli, 1980.

FONTE: Progetto Bicocca: invito alla progettazione urbanística e architettonica di un centro tecnologico integrato. Milano: Pirelli, 1984, p. 52.

Fig. 58 - Corte da torre de esfriamento com projeto da nova sede da Pirelli. FONTE: Desenho fornecido pelo escritório do arquiteto Vittorio Gregotti.

Fig. 59 - Foto da torre de esfriamento da Pirelli visto de cima no início obras do projeto de requalificação, 2003.

FONTE: Costruire, n²37, Editrice Abitare Segesta, fev. 2003, p. 50.

Fig. 60 - Foto da torre de esfriamento da Pirelli dentro do edifício invólucro da torre.

FONTE: Costruire, $n^{\circ} 237$, Editrice Abitare Segesta, fev. 2003, p. 50.

Fig. 61 - Foto da ex-torre de esfriamento/Nova sede geral da Pirelli - Bicocca, 2004.

FONTE: Abitare, n439, Editrice Abitare Segesta, maio 2004, p. 101.

Fig. 62 - Torre de esfriamento da Pirelli em obras de requalificação, visto da avenida de acesso à cidade.

FOTO: Marisa Barda 
Fig. 63 - Antigos hangares, hoje espaços usados para exposições em geral. FONTE: Marisa Barda

Fig. 64 - Bicocca, praça na proximidades da Universidade de geologia FONTE: <www.mib.infn.it/layout/bicocca.jpg>, acesso em 04 jan. 2007. Fig. 65 - Praça na Universidade de Ciências, Bicocca 2001. FONTE: I quaderni della Bicocca 01: 1985- 1998. Milano: Skira, 1998, p. 19. Fig. 66 - Praça na Universidade de Ciências, Bicocca 2001. FONTE: I quaderni della Bicocca 01: 1985- 1998. Milano: Skira, 1998, p. 20. Fig. 67 - Planta geral do projeto Bicocca de Gregotti e os tipos de uso. Fonte: I quaderni della Bicocca 01: 1985- 1998. Milano: Skira, 1998, p. 109. 